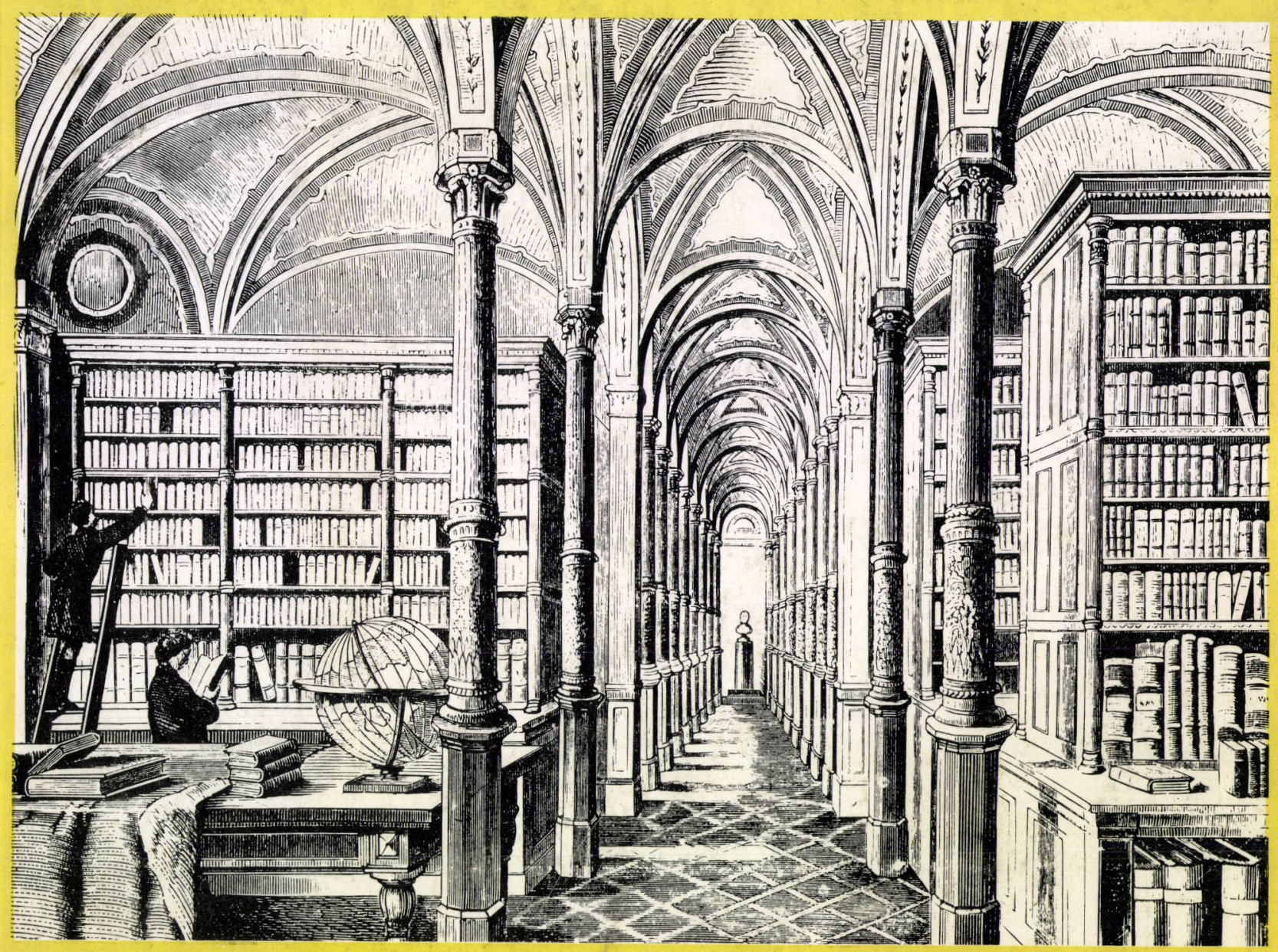

\title{
THE LIBRARY \\ OF THE HUNGARIAN \\ ACADEMY OF SCIENCES
}

\section{6-1976}





\section{THE LIBRARY}

OF THE HUNGARIAN

ACADEMY

OF SCIENCES

1826-1976

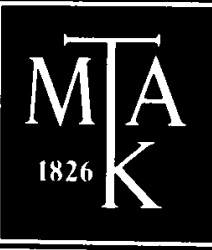

\section{BUDAPEST • 1976}


Edited by G. Rózsa, director, with the collaboration of

G. Fekete, D. Csanak, E. Szeidovitz, D. Székely, L. Tökés

Photographs were produced by the Photographic Laboratory of the Library of the Hungarian Academy of Sciences

ISBN 9637301135 
THE LIBRARY OF THE HUNGARIAN ACADEMY OF SCIENCES

1826-1976 
150 years ago, on 17th March 1826, Count József Teleki donated his family library of 30000 volumes to the Hungarian Learned Society. With this he established the first scientific institution of the Academy just some half a year later than the offer of Count István Széchenyi had given an impulse to realizing the plan of a Learned Society to which efforts had been made by Hungarian scholars of the former century.

Count Teleki, a famous historian of that period, later the first president of the Academy, had intended that 'the library should promote the study of the Hungarian language and by this means the Learned Society just about to be organized for the cultivation of sciences should be able to fulfil the task entrusted to it with the success expected of it.'

Although the initial impetus, - in consequence of which the Academy had obtained its first scientific institution of major importance even before the royal assent was given -, did not continue with undiminished energy, nevertheless in the course of time the Library of the Academy continued to increase and soon it became of national importance. Scientific connections quickly crossed the borders of the country, and it was not lacking in recognition from abroad.

With World War II ended, after the country's liberation the Library of the Academy made a rapid-rate progress as a consequence of the role the sciences obtained in building a socialist system. At that time -25 years ago - the highly respected Oriental Collection was also established.

With three decades passed since the liberation, the Library has also been growing parallel with the intensive development of Hungarian scientific life, and has become one of the most important bases of it. Apart from paying homage to the historical past and patronizing progressive traditions its main effort is to serve present research and public life with up-to-date library-tools, as well as with an adaptable system, in cooperation with other large libraries among whom there is a reasonable distribution of the fields of collection.

The growing complexity of the information demands of research activities of our days and the rapid increase in professional literature justified, - to a certain extent -, that the special libraries of the Academy's research institutes should be brought under the professional supervision of the Academy's Library. In this way, 
holdings containing a special literature of more than 2,5 million items are at the disposal of scholars and scientists, of which the central Library contains 1,5 million items.

The days when the Library simply shelved books for use by exclusive visitors are long gone. In accordance with recent demands the Library's function has undergone considerable changes. Its active role in the extensive support of creative work has developed and its transformation into a scientific institute is also of great moment. It helps public activities and research not only with its regular information on acquisitions of old and rare books and of recent ones as well as periodicals of major importance, it helps not only with its exchange relations involving 1600 institutions of about 90 countries, but, in the first place, with its substantial information service on science policy and bibliography, moreover with the research work of its own staff it contributes to the developing of the country.

This booklet gives only an outline of the Library and some of its major characteristic activities, commemorating respectfully the 150th anniversary of its foundation and manifesting - with responsibility towards the country - its present function of serving progress.

Budapest, March 1976.

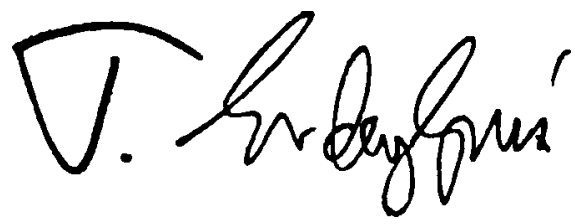

President

of the Hungarian Academy of Sciences 


\section{HISTORICAL OUTLINE}

The Library of the Hungarian Academy of Sciences, one of the most important public collections in Hungary, was founded 150 years ago. The central Library and the research library network form the most substantial basis for scientific information in our country. The majority of the holdings - about 2,5 million items - consists of scientific publications; old books and periodicals, as well as most up-to-date publications can be found in them. The Library was the only institution of the Hungarian Academy of Sciences from its foundation (1826) till the reorganization of the Academy (1949).

The Library - not unlike the Academy - was established by Hungarian society as a great achievement of the Reform Age.

\section{$1826-1865$}

In the 18th century and at the beginning of the 19th century almost all the plans and attempts urging on founding societies for the promotion of science, knowledge of our country, cultivation of the Hungarian language realized the necessity of having their own libraries." The establishing of the Academy of Sciences (3rd November 1825) on Count István Széchenyi's initiative was followed by laying down the foundations of the Library on 17th March 1826. A historian, the first president of the Learned Society, Count József Teleki offered his family library of 30000 volumes to the Learned Society. In his foundation deed he emphasized that he wanted his family book collection to become the property of the Learned Society and 'a public property to be used by all citizens of the country'. The proper role of the Library was indicated in the foundation deed taking into consideration the existence of the National Széchényi Library and that of the University Library. His aim was not an institution with a narrow scope and limited admission meeting the demands of an exclusive

\footnotetext{
*Mátyás Bél, Péter Bod, Dániel Fischer, Dániel Tersztyánszky, Ảdám Kollár, György Bessenyei, Miklós Révai, Sámuel Decsy, György Aranka, László Teleki, István Sándor, István Kultsár, Pál Felsőbüki Nagy and others.
} 
scientific body only, - unlike similar institutions in most countries -, but he had in mind the establishing of a large scientific library of universal character. The foundation deed gave a special character to the Library of the Hungarian Academy of Sciences, as well as to the whole library system in Hungary remaining operative up to the present, i.e. in Hungary three institutions - complementary to one another -, the National Széchényi Library, the Eötvös Loránd University Library of Budapest and the Library of the Hungarian Academy of Sciences have jointly served as a central large library complex of general scope.

The Learned Society started its activities in 1831, while the Teleki-library was given over to the Society only in the 1840s. On its first premises rented in the Deron-house on the site of what today is Gresham-palace at Roosevelt Square, the Academy did not have enough room to shelve its 30000 volumes, therefore the Teleki-collection remained in the palace of the family at Szervita Square (today's Martinelli Square). The other part of the Library, which was increasing rapidly by means of donations, acquisitions, subscriptions and exchanges, was shelved in the Deron-house.

Greater donations of the first decade were those of Count József Teleki. It was he who bought - among others - the so-called Kresznerics-collection of books and coins. In 1835 Livius Marczibányi gave the Academy part of his father's, István Marczibányi's library. Considering the quantity of books, an important acquisition was when the library was presented with 30000 volumes of Gusztáv Batthyány's library in Rohonc; a smaller but precious collection was the present of his brother, Kázmér Batthyány which consisted of 2660 volumes and contained the books of archbishop József Batthyany. In 1845 the Academy acquired István Sándor's library which was still extant. He left his collection of books, paintings and coins to the Academy to be founded by will in 1814, and at the same time an endowment of 10000 forints for the purposes of the Institution.

The Academy's members also added works of high value to the Library, e.g. István Széchenyi, Farkas Bolyai, Ferenc Kazinczy, János Irinyi, Mihály Vörösmarty, András Fáy, Pál Bugát, Ferenc Toldy, Gergely Czuczor, Antal Reguly etc. Others, besides them, - people of all social strata - presented the Library with books. Thus was it that the Library happened to acquire part of contemporary scientific works, although this kind of accidental acquisition was not to replace a systematic and regular one. In the 1830s the Academy could purchase domestic and foreign publications only on an annual budget of 100 to 300 forints. Deposit copies of Hungarian books flowed in from 1837 under a royal priviledge and under copyright acts after 1840, except the 1850s when the Academy was deprived of this way of acquisition.

From the beginning the Society was keen on acquiring the most important scientific periodicals, it subscribed to 7 in 1831 , to 17 from abroad and to 8 in Hungary in 1841, and the number of subscriptions continued to rise.

International exchange relations were particularly important sources of acquisition both in quantity and in quality. The first ones were established in 1832-33, and the first partner was the Philosophical Society of Philadelphia. 
- Its president, later corresponding member of the Academy, Du Ponceau wrote on 5 th January 1833 that he would be pleased to send on exchange the year-books of the Society issued from 1770. The first Annual of the Academy published in 1833 was sent to the following societies: Institut de France, Royal Society of London and Edinburgh, American Philosophical Society, Bayerische Akademie, Göttingische Akademie, Deutsche Akademie der Wissenschaften zu Berlin, Academy of St. Petersburg, Royal Asiatic Society of Calcutta, Czech Scientific Society, and a year later the Florence Academy, Archaeological Academy of Rome, Royal Swedish Academy. In the covering letter of the exchange copies president József Teleki and the secretary-general Gábor Döbrentei drafted the principles operative up to the present: the exchange of publications is a means of scientific cooperation and solidarity of mankind fostering the sciences and arts. The first sending of exchange copies made it possible to establish personal contacts among the members of different national academies. It was the founder and vice-president of the Hungarian Academy, Count István Széchenyi, who presented the first volumes of the Annual to Schelling at the Bayerische Akademie, to Gay-Lussac at the Institut de France, and to the Earl of Sussex at the Royal Society in London and in the name of the Hungarian Academy he personally addressed the sessions of the above institutions in Paris and London.

By the means of exchange relations the Academy joined in the circulation system of the world of science and at the same time the Library managed to acquire invaluable publications. A great amount of modern scientific publications were given to the Library on exchange, and later, under difficult financial circumstances, it was the international exchange which - several times remained the only real possibility of acquisition.

At the beginning codices, linguistic records and manuscripts were mainly presented to the Library by donators. In the 1830 s the copying of materials related to Hungary in foreign and Hungarian archives and the collecting of the literary remains of scholars and scientists were started.

The public character of the Library in the first years could not be guaranteed with much success. The use of the Teleki-collection had been allowed by the family twice a month before it was taken over by the Library. As far as the existing holdings of the Academy are concerned, owing to lack of space, equipment and personnel, it was only the periodicals and latest publications purchased or given on exchange which were accessible to members wanting to gather information. In 1836 the Academy moved from the premises of Deronhouse to Trattner-Károlyi-house at 612 Úri Street (the present 3 Sándor Petőfi Street), where in 1837 - following the offices of the secretary-general - the Library also succeeded in getting four larger rooms and four smaller ones.

Systematic processing could be started. The archivist Gergely Czuczor began to compile the first alphabetical catalogue in book form which was continued by his successors till 1841. It contained a short description of the miscellaneous materials stored by the Academy. The sorting and cataloguing of the total 9 holdings were carried out by the secretary-general Ferenc Toldy with the help of 
one clerk. First the 4500 to 5000 volume holdings acquired either by purchase or on exchange or donated were processed. That was followed by the two Batthyány-libraries containing 30000 to 32000 volumes altogether, and finally the major part of the 20000 volume Teleki-library was taken over. According to the foundation deed the latter was to be kept separately from publications coming from other sources. Consequently there was a double storage in the Library.

Having finished the processing, the Library was opened to the public on $23 \mathrm{rd}$ December 1844. On this o.ccasion, the poet Mihály Vörösmarty wrote his ode Gondolatok a könyvtárban (Thoughts in the library).

Because of limited means at the time the 50 to 60000 volume holdings could be used only by members of the Academy, while other scholars and scientists with special permission only. The public character which had been aimed at by the founder could not be realized at that time. The first Directives issued by Ferenc Toldy in 1848 raised the processing to contemporary level.

With restrictions put on the Academy's activities during the years of neoabsolutism, the interests of the Library were also vitally concerned. It was temporarily deprived of its right to deposit copies. Accessions were limited to materials of international exchange and donations of great value (manuscript collections of Gábor Döbrentei and György Gaál, the Jancsó-, Czech-, Somssichlibraries).

\section{$1865-1949$}

The 1860's brought forth decisive changes both for the Academy and for its Library. The Hungarian society launched a national movement succeeding in raising to 900000 forints the capital of the Academy - the representative of the nation's spirit -, and in addition to all this, another national contribution of 600000 forints made it possible to build the present palace of the Academy by 1865, designed by August Stüler, carried out under the guidance of Miklós Ybl and Antal Skalnitzky. The Library's move into the palace meant proper premises and up-to-date technical equipment.

Within two years (1865-1867) the holdings in the palace were rearranged according to a new shelving system, based on the character of the collection rather than on a theoretical system of sciences. The former separation was abolished, i.e. the Teleki-library was united with the other materials in a new subject order. A new catalogue-system was made, which consisted of topographical, alphabetical and subject catalogues. This work was done by the linguist and chief librarian Pál Hunfalvy, the linguist József Budenz and the archaeologist Flóris Rómer. In the new building it was possible to satisfy the demands of a wider circle of readers, although the restricting of the use of the Library prevented it somehow from becoming really a common property.

The Library Committee attached to the Academy's Presidium and to the Board of Directors was set up in 1865 . Its first chairman was Ferenc Toldy, members 
were János Arany, Cyrill Horváth, Ányos Jedlik, Tivadar Pauler, Ottó Petzval, Gusztáv Wenzel as well as two librarians, Pál Hunfalvy and József Budenz, all of them prominent scholars and scientists. The restricted initial activities of the Committee were more and more extended; from 1875 it was responsible for almost all the tasks of the Library, i.e. the ways of processing and using, providing additional staff, new stackrooms, possibilities for acquiring new large collections of maruscripts and books (the library of Dániel Szilágyi, the manuscripts of Sándor Kisfaludy etc.). The Library Committee worked till 1949, the year of the Academy's reorganization.

József Eötvös, minister of education supervised the situation of the greater libraries in Pest in 1869, and he tried to co-ordinate their activities. On the proposals of Ferenc Toldy, director of the University Library, the minister prescribed the field of collection of the Library of the Academy. According to it the Library collected publications of scientific societies and institutions abroad, the most important scientific periodicals, dictionaries, works on linguistics and literary history, encyclopedias and handbooks, as well as more important monographs. The annual budget of 1000 forints for foreign purchases did not make it possible to maintain the collection at a contemporary level, since the holdings mainly consisted of heterogeneous donations and purchased collections. That is why Eötvös granted the Library 5000 forints annually for purchases from abroad.

In this way and with the growth of exchange relations (the number of partners increased from 100 in 1865 to 230 in 1910), the Library managed to get valuable publications in those years. Important additions were the acquisition of Pulszky, Gusztáv Hadik, Waldstein, Siskovits, Reiner and Lajos Katona-libraries, especially the Ráth-library containing mainly Hungarian books published before 1711, and the Kaufmann-collection consisting of Hebrew books and manuscripts.

Although signs of crisis had appeared in several respects at the end of this period (processing slowed down, the scientific character of the holdings faded with non-scientific publications flowing in, adequate space for stack-rooms decreased etc.), it was World War I which created a catastrophic situation. The number of deposit copies of Hungarian books decreased, exchange relations were either cancelled or limited to institutions of the allied countries, the readers also decreased and the Library grew more and more isolated from the developing trends of other Hungarian libraries.

The situation was not more favourable till the mid-1920's. Because of financial troubles of the state the endowments of the Academy lost their value, inflation hindered purchases of books from abroad, the lack of the Academy's own publications made it impossible to reestablish exchange relations. Some of the academies abroad (London, Edingburgh, Rome) continued sending their publications without compensation. Apart from this, a small number deposit of copies of the Hungarian publishers was the only means of acquisition. Because of heating problems the reading rooms were almost empty. They could not provide the 11 library with proper personnel, and it only made the situation worse. 
Circumstances changed for the better with the economic stabilization and almost at the same time (in 1925) Zoltan Ferenczi was appointed the chieflibrarian, who had a good deal of experience both in theory and practice. He started subscriptions to the most important periodicals again, and revived exchange relations. He procured new stack-rooms making it possible to house the whole stock in an adequate way. After his death this dynamic growth came to a stop. Discontinued acquisitions during World War I and the following years ought to have been made up for and the uncatalogued material processed.

The Academy received as a bequest by Count Ferenc Vigyázó not only an estate, but an extraordinary valuable library of 17000 volumes (a rich collection of rare books, precious codices, incunabula and old Hungarian books), in addition the library of Aurél Stein and the Kégl-library, both of which contained oriental material. These collections and other former arrears were processed, but the making up for gaps in acquisition and that of new scientific publications were neglected.

The Vigyázó estate might have been profitable for the Academy, but the economic crisis and later the outbreak of World War II prevented the proper exploitation of the estate for Hungarian scientific life.

The period between the two World Wars was nothing but years of decline in the Library's history. It became underdeveloped and was closed to a wider public. Work in the Library was carried out under more and more unfavourable circumstances, without having enough personnel. Purchases were accidental, deposit copies essentially involved a quantitative growth only, thus merely increasing the existing want of space.

One merit of this period was the developing of exchange relations: between 1929 and 1938 exchange agreements were established with 450 institutions and despite the contemporary government's chauvinistic attitude to cultural policy, the Library continued maintaining relations with the academies of neighbouring states, even with those of the Soviet Union (Moscow, Leningrad, Kiev).

During World War II, when the country was a theatre of war, the main task was to save the stocks. The most valuable manuscripts and rare books were deposited in the air-raid shelter of the Academy's building, of the National Bank and in the cave-cellars under the Castle Hill. The palace of the Academy, in its exposed site, was hit several times during battles, but fortunately the stocks suffered relatively slight damage. In 1944, the year of the centenary, the Library was in a state of total paralysation. Services came to an end, there were neither lights nor heating in the building, all activities were suspended, stack-rooms and premises without windows were exposed to devastation.

\section{$1949-1976$}

After the liberation of the country restoration works were started with great difficulties. Manuscripts and books, having been put in safe places, were brought back successfully. 
From 1946 exchange relations were renewed with the Academy's six Acta published in foreign languages. International relations were established with only 65 institutions in 1947 and this was raised to the level of 254 by 1949.

In 1949 with the help of the government the reading room for books and the one for periodicals were re-furnished and other rooms were restored, too. Because of longer opening hours the number of readers increased. Acquisition of books and periodicals also increased with 7000 publications, 530 foreign and 170 Hungarian periodicals in 1948. The Manuscript Department was reorganized and the organization of the Oriental Collection started. The increasing number of librarians made it possible to fulfil more and more new tasks. After the years of isolation and after restoring the devastations of the war the Library was able to recognize its tasks, to modernize its organization and methods so that it could efficiently serve the Academy and the Hungarian world of science.

Pursuant to the Act XXVII of 1949 on the reorganization of the Academy, the Hungarian Academy of Sciences became the supreme scientific body of the country and this opened a new area in the history of the Library, too. The Academy become responsible for the top-level management of research works, defining the main trends in research, and for ensuring creative cooperation between scientific activity and practice. Within the framework of the Academy a network of research institutes has gradually developed. The Library's new scope of activities described in the directions of the Academy's Presidium in 1953 is as follows:

1. The Library of the Academy supplies Hungarian scientific research with Hungarian and foreign documents (books, periodicals, manuscripts, microfilms);

2. through regular exchange relations, it sends Hungarian special literature, particularly publications of the Academy, to foreign scientific institutions, moreover it acquires scientific publications from abroad by means of intensive exchange relations;

3. it renders the institutional libraries affiliated to the Academy's network different services and gives them professional assistance;

4. it takes part in the nation-wide inter-library work aimed at developing the Hungarian socialist library system;

5. as an independent scientific institution it conducts researches in the fields of library science and other specialized branches of knowledge.

The instruction of 1953 by the Academy's Presidium and the orders of 1958 and 1968 by the Minister of Education deals with the scope of the Library within the framework of nation-wide library system.

The new tasks necessitated the reorganization of the Library itself. In 1950 the Library changed over to the so-called belt-system of processing, to the Universal Decimal Classification (UDC) and from the former system of shelving books in an arrangement by broad subject fields, the Library turned to current number of accession order of shelving. An up-to-date network of catalogues has been built up. In 1953 the Information and Bibliographical Department, the Microfilm 
Collection and Photographic Laboratory and the Group of Library Network and Methodology were established. The Periodicals Department became independent in 1954. The Department of Manuscripts and Old Books was set up by the reorganization of the Manuscript Department and Collection of Old Books. The Oriental Collection belonging to the special collections since 1951 became independent in 1957. A bookbindery started working in 1958. The Archives of the Academy, which processes and preserves the documents of the Academy's activities were reorganized within the framework of the Library in 1963. The Xerox Service and the Group of Mimeography were set up in 1968 and in 1970, respectively.

In 1953 the Academy set up the Library Council which has been functioning under the name Library Committee since 1962.

The present organization of the Library is as follows:

Under the direct control of the director:

Secretariate

Group of Library Network and Methodology

Group for International Library Relations

Independent units:

1. Acquisition Department

2. Processing Department
a) Group of Cataloguing
b) Group of Classification

3. Department of Readers' Service
a) Central Readers' Service
b) Group for the Control of the Holdings
c) Book-Bindery

4. Information and Bibliographical Department
a) Group of General Information
b) Group of Science Organization Information
c) Editorial Group
d) Group of Mimeography

5. Periodicals Department

6. Department of Manuscripts and Old Books

7. Oriental Collection

8. Archives of the Academy

9. Department of Reprography

a) Group of Microfilms and Photographic Laboratory

b) Xerox Service 
10. Department of Economic Administration

a) Group of Finance and Accountancy

b) Group of Maintenance

c) Group for Handling the Surplus Copies of the Academy's Publications 


\section{THE WORK AND USE OF THE LIBRARY}

The Library of the Academy is a specialized research library of nation-wide level. In the first place it is at the disposal of scholars and scientists doing research work within or without the framework of the Academy. Its use is free."

\section{Acquisition policy, international exchange, holdings}

After the reorganization of the Academy the instruction of 1953 by the Academy's Presidium and the orders of 1958 and 1968 by the Minister of Education dealt with the scope of collection of the Library within the framework of the nation-wide library system. The orders paid regard to the traditionally developed scope of collection, the objectives of the Academy's science policy, and last but not least to its place in the national library system. In compliance with these tasks the scope of the Library includes:

1. literature of marxism-leninism;

2. publications of foreign academies of sciences and literature relating to their activities;

3. literature concerning science policy, organization and planning of scientific research and the related subject fields;

4. standard works on social and natural sciences (including those on science history) and general, bibliographical and reference works;

5. as a specialized research library, it acquires, on a nation-wide scale, the literature on the following subjects:

a) ancient history and classical philology;

b) literary scholarship (comprising history of world literature and works of contemporary writers of world literature);

c) oriental studies;

d) all branches of linguistics.

*Opening hours: on Mondays-Fridays from 9 a.m. to 8 p.m., on Saturdays from 9 a.m. to 5 p.m. 
- The Library makes efforts to acquire publications dealing with the general, methodological, ideological and interdisciplinary aspects of the social sciences.

As regards periodicals, the field of collecting is more comprehensive because of exchange activities on the one hand, and of the interests of basic research on the other.

Of old books it acquires mainly works which are important from the point of view of the history of science. As far as manuscripts are concerned, it collects first of all the ones related to the Academy, to the history of literature and science.

From the very beginning international exchange activities have had an important role in acquisition. Their main tasks are: 1 . exchange of publications of the Academy based on bilateral agreements of institutions (first of all those of the Acta and other scientific periodicals and books, sometimes published not by the Academy); 2. exchange of publications guaranteed by inter-governmental and inter-academic agreements and arrangements with socialist countries.

The significance of exchange goes far beyond its important function as a means of acquisition. It serves the aims of cultural and science policy, as it sends the Academy's publications reflecting the achievements of Hungarian scientific life to every part of the world.

At the end of 1975 the Library had exchange relations with 1590 scientific institutions in 87 countries. The volume of exchange activities can be shown by the fact, that in 19754891 books and 8186 numbers of periodicals were sent abroad, while the Library obtained 7439 books and 5362 periodicals by exchange.

The Library has regularly been buying and keeping publications of the Academy in several copies since 1950. The surplus copies - together with the materials of the former Publishing House of the Hungarian Academy of Sciences brought to the Library after the liberation of the country - make it possible to satisfy demands on an exchange basis retrospectively.

By the end of 1975 the Library had accumulated 1404665 items. Their break-down by types of documents is as follows:

796897 volumes of books

203647 copies of periodicals

388362 pieces of manuscripts

15759 microfilms

\section{Catalogues}

The entrance hall opens into the catalogue-room, which communicates with the main reading room on one side and the main stack on the other. It functions as circulation-room, too. Here can also be found the alphabetical and the UDC

17 catalogues, as well as the catalogue of the old material which still is shelved in an 
arrangement by subject matter. To the right of the entrance hall the door opens into a small room where the series card catalogue is to be found, since serials are entered in the above catalogues as single publications. Beside it the geographical catalogue, also based on UDC, is installed. All these catalogues are at the disposal of the readers. Besides them there is a so-called main author catalogue for the use of the staff, and, in addition, a shelf list.

Besides the above mentioned alphabetical and classified catalogues the special collections of the Library have their own ones.

\section{Reading Rooms}

In accordance with the holdings of the Library there are different reading rooms and study rooms at the disposal of the users: 1. main reading room; 2. periodicals reading room; 3. reading room of the Department of Manuscripts and Old Books; 4. reading room of the Oriental Collection; 5. reading room for microfilms.

1. The main reading room is on the ground floor. It opens to the left of the entrance hall. A reference library of 3000 volumes is located there in bookcases along the walls, arranged by subject fields to which readers have free access. Books of this collection, dictionaries, encyclopedias are regularly replaced by others, except for some basic handbooks, so that the most up-to-date reference books of all specialized branches of learning are always available for scholars and scientists.

2 . The periodicals reading room communicates with the main reading room. The latest volumes of 1200 periodicals of the 5000 serial titles (journals, yearbooks etc.) received by the Library can be found on the shelves along the walls.

3. The reading room of the Department of Manuscripts and Old Books is on the first floor. A staircase from the courtyard leads up to it.

4. The reading room of the Oriental Collection is at the corner to the right on the ground floor.

5 . The reading room for microfilms is on the ground floor facing Akadémia Street, accessible to the right from the vestibule of the Academy. Three microfilm readers are available simultaneously.

\section{Lending Service}

The Library of the Academy in consequence of its nature lends books to a limited extent. Book lending service is at the disposal of the Academy's members, scholars and scientists having a postgraduate degree, scientific staff-members of the Academy's and other research institutions, research libraries and university professors. The loan period is one month. Serials, reference books, dictionaries, 
publications of high value, periodicals, old books, manuscripts are not to be lent out. In such cases it is reasonable to turn to the: Department of Reprography. If books are concerned, it is the Department of Readers' Service which enters orders, in case of materials belonging to special collections, the respective collection is competent. International and Hungarian interlibrary loan can be claimed by the readers. It is carried out directly by the Department of Readers' Service.

\section{Information Services}

The Department of Readers' Service gives answers to verbal or written requests concerning the holdings of the Library or a relatively more simple reference. If it is necessary, the above department shows the readers the ways of using catalogues and the Library as a whole, looks after the reading rooms, circulation, shelvings, and directs the readers' attention to recent acquisitions. The latter is being done in two ways: 1 . in the show-cases of the entrance hall it displays the dust covers of the most important books received recently; 2 . in cooperation with the Processing Department it compiles The List of Recent Foreign Acquisitions of the Library of the Hungarian Academy of Sciences, which gives the readers information about the total acquisitions of the Library and is issued in subject order, six times a year.

In cooperation with the Department of Readers' Service, the Information and Bibliographical Department is responsible for meeting demands on bibliographical information and literature research. The Department usually gives written answers to requests (in the form of bibliographies, literature researches, syntheses etc.) from time to time in the form of consultation.

Similarly continuous editing and administration of a special bibliography, recording scientific works of the members of the Hungarian Academy of Sciences (this bibliography is at the disposal of readers in the building itself), and collecting various data on the Academy are also among the tasks of the Information and Bibliographical Department.

A group of the Department has been editing the Bulletin of Science Organization a bi-monthly journal since 1961 . This periodical gives information, based on international special literature on science policy, organization, management, and planning of scientific research in the form of informational syntheses, reviews, surveys, critiques and special bibliography. It is published in 60 author's sheets. Its articles are either taken over or reviewed in scientific journals, home and abroad. At the same time the Group fulfils other informational tasks related to its field of interest, and is capable of giving prompt and adequate information to leading bodies of science policy in the country, to heads of these bodies and to researchers in these fields according to their respective interest.

In connection with the information activities it should be mentioned that each special collection is performing informational activities in its particular field of

19 research. 


\section{Publishing Activities}

The Editorial Group and the Group of Mimeography belong to the Information and Bibliographical Department.

The task of the Editorial Group is the editing and preparation for printing of serials of the Library, catalogues of different special collections and of other works edited by the Library. The prepared material is printed by the Group of Mimeography. (The list of the Library's publications is shown in the appendix.) Besides this the Group produces the prints necessary to the use of the Library.

It should be mentioned here that the Library has its own bookbindery which besides bookbinding does restauration work, too. 
Special collections are those units of the Library which are in themselves responsible for basic library works such as acquisition, processing, readers' service, reference service, and according to the appropriate character of their holdings they exist as 'libraries within the library'.

\section{Periodicals Department}

The Library's Periodicals Department is the country's largest collection in the field of the humanities. It has a great importance also in the field of general social sciences and of basic research in the natural sciences. The holdings consist of about 12500 periodical titles, and of which approximately 5000 titles are current foreign periodicals. The Periodicals Department is the richest treasurehouse of periodicals issued by foreign academies and scientific societies.

As a result of exchange activities of one century and a half, the Library of the Academy is in the possession of almost complete series of rare periodicals such as those of the academies of Austria, St. Petersburg, Bavaria, Saxony, Belgium, the Netherlands, Great-Britain and France, which have a unique value in our country, to mention only a few examples of important periodicals with great past: the Philosophical Transactions of the Royal Society of London, Journal des Savants, Doklady Akademii Nauk USSR, Proceedings of the Royal Society of London, Comptes Rendus Hebdomadaires des Séances de l'Académie des Sciences de Paris, Sitzungsberichte, Österreichische Akademie der Wissenschaften.

The rules for using periodicals are the same as for books with the difference that they may not be lent. The Periodicals Department is an independent unit; it carries out every working process related to all periodicals. Its most important tasks are as follows: acquisition in cooperation with exchange activities, handling of various registers, cataloguing and classifying periodicals, building proper catalogues, preservation and shelving of periodicals and readers' service. The latest handbook on its holdings, published in 1973, is an alphabetic and subject

21 index of periodicals. 


\section{Department of Manuscripts and Old Books}

The acquisition of manuscripts was started at the time when the Academy's Library was founded. The way of acquisition of manuscripts was laid down by the General Assembly of the Academy as early as 1832 prescribing 'the acquiring of hidden old Hungarian manuscripts, either, if possible, in original or at least in copies.'

The Teleki-library included about 600 volumes of very valuable manuscripts, among others, correspondence and works of eminent scholars in the 18th century (such as Dániel Cornides, József Benczur and others). Donations of the president József Teleki were adding to all these, among others, one authentic Corvinuscodex De laudibus Matthiae regis by Ludovicus Carbo, some other medieval codices, 76 hand-written volumes of the Kresznerics-collection etc. The Library managed to obtain several linguistic records, such as the Czech-codex, the Guarycodex, the Virginia-codex, a prayer-book of Benigna Magyar, the Ersekújvárcodex etc. Some of them were donated, others were given on exchange for the series of publications 'Old Hungarian Linguistic Records' (Régi Magyar Nyelvemlékek). Deserving special mention among the personal and literary remains of great writers are the correspondence and manuscripts of Ferenc Kazinczy which came first to be among the highly valued possessions of the Department, later those of János Arany, János Batsányi, Dániel Berzsenyi, György Bessenyei, Ferenc Kölcsey, Mihály Csokonai Vitéz, Sándor and Károly Kisfaludy, as well as literary remains of scientists like Ottó Herman, Lajos Katona, Bernát Munkácsi, Ákos Pauler, Salamon Petényi, Antal Reguly, Ferenc Toldy, some works of the two Bolyais and others. The Secretary-General's office has been continuously handed over to the Manuscript Department, hand-written papers which were entered in competitions conducted by the Academy, later on library documents and other official ones concerning the administration of the Academy, as well as copies of works related to Hungary which were made in libraries and archives abroad - the latter activity also being sponsored by the Committee on History.

Since the reorganization of the Academy (1949) the Department has an annual budget which enables it to acquire manuscripts regularly, consequently the Department, which earlier obtained new accessions only by donations or accidental purchases, has multiplied its collection. Since 1950 - among others the following very precious literary remains of scholars and scientists have come to the Department of Manuscripts: a considerable amount of the literary remains of Endre Ady, manuscripts of Babits, literary remains of Béla Balázs, Ákos Dutka, Dezső Kosztolányi, Lőrinc Szabó, manuscripts of Árpád Tóth, letters from Romain Rolland and from Zsigmond Móricz, some writings of Dezső Szabó, the correspondence of the Tevan Publishing House with the outstanding figures of modern Hungarian literature, the literary remains of Péter Veres, Máté Zalka, as well as those of Péter Ágoston, Ödön Beke, Béla Bulla, István Csekey, Sándor Domanovszky, Loránd Eötvös, Lajos Fülep, István Hajnal, Ágost Heller, Farkas Heller, Ferenc Kováts, Imre Lukinich, Erik Molnár, Gyula Moravcsik, Mór Réthy, 
Márton Roska, István Szabó, Gyula Szekfü, Zoltán Tóth, Endre Veress, Béla Zolnai and a rich collection of the correspondence of Nobel-prize winners (W. Heisenberg, M. Planck, György Hevesy, Jenő Pál Wigner, Albert Szent-Györgyi). Since 1952 the Manuscript Department has been in charge of the doctoral and candidate's theses. Following its reorganization, the Manuscript Department also became the recipient of the following materials: manuscripts from museums, materials from the former memorial rooms of the Academy, the Széchenyimuseum, the Goethe-room, the Vörösmarty-room, the Mikszáth-room, and the manuscripts of the Kisfaludy Society which had carried on its activities in the building of the Academy until it was suspended. At present there are more than 388000 items on file in the Manuscript Department.

Formerly, manuscripts had been kept in the Secretary-General's office under the supervision of the archivist in office (Ferenc Toldy, Gergely Czuczor, László Szalay). It became an independent collection in 1865. The archaeologist Flóris Rómer was the first to be the keeper of records. At the time the Department had been moved to a ground-floor room facing the court-yard of the building, and after the reorganization in 1949 it was given four re-furnished rooms of the Secretary-General's former offices.

The older material of the Manuscript Department was arranged in subject order, and the last subject of this classification scheme made in 1865 was reserved for manuscripts, and this subject group practically made up an independent subject order inside that of the Library. Until 1954 every manuscript was incorporated in this subject order. In 1954, the Department - preserving the former order made according to subjects - introduced a more practical, new order based on current numbers which made it possible to shelve the related manuscripts together according to provenance.

A shelf-list and two kinds of alphabetical catalogues (one for manuscripts and analects, another for letters) recorded on cards were made from the manuscripts in subject order. The cards of manuscripts processed since 1954 were arranged in a single alphabetical catalogue covering both author and subject. The new shelflist is issued in book-form. The handbooks Catalogues of the Manuscript Department of the Library of the Hungarian Academy of Sciences have been published since 1966.

The antecedents of the Old Book Collection were the incunabula which, in the subject order of 1865 had been a sub-class of old Hungarian literature within the class of Hungarian literature.

The Collection of Old Books was fused into one Department with the Manuscript Department in 1954. It is made up of the following parts:

1. The collection of incunabula. It contains approximately 1200 incunabula, of which 391 items belonged to the Teleki-collection, 429 to the Vigyázó-library, 147 concerning Hungary belonged to the Ráth-collection.

2. The collection of old Hungarian books consists of 6372 volumes, of which 4010 were either acquired by the Library or originated from various other 23 sources, 2362 belonged to the Ráth-collection. 
3. Old books (Antiqua as they are called) published between 1501 and 1550 .

4. Museum pieces. Publications of extremely high value, books with precious bindings, parts of writers' libraries and other rare books.

5. Hungarian and foreign books published before 1850 and 1800, respectively, are gradually transferred from the Library's re-catalogued holdings to the Collection of Old Books.

Entries of old books are arranged in one single alphabetical authors' catalogue. Except the cards of incunabula and of old Hungarian books, the entries are also put into the central catalogue of the Library. The collection has built up catalogues based on chronology and binding, too.

In the last quarter of the century important conserving and restoring works have been carried out at every unit of the Department.

\section{Oriental Collection}

The reading rooms of the Oriental Collection were designed in 1950 and they are on the ground floor of the Academy's building in the corner formed by Akadémia Street and Roosevelt Square. It was opened in the spring of 1951 to form the library basis for oriental studies (which have long traditions in our country) and for training orientalists. With its organization a long-standing need of Hungarian oriental studies was met.

When the Collection was established it consisted of 15000 books and 1000 manuscripts. Even before its foundation, our orientalists had rendered inestimable services by presenting the Library of the Academy with their collections of books and manuscripts, frequently with their total private libraries. At the end of the last century and in the early 1900's through Tivadar Duka the Library of the Academy was given the books and Tibetan manuscripts of Sándor Körösi Csoma, the founder of Tibetan studies, together with Duka's rich collection related to Körösi Csoma. By his will, the hebraist, David Kaufmann left the Library his extremely valuable hebraistic collection. This Kaufmann-collection, having a good international reputation, includes 594 manuscripts, 2000 printed books, among them unique illuminated Hebrew manuscripts from the 11th century onwards, incunabula and in addition to these the Geniza-collection. After the death of the turcologist, Armin Vámbery, his son, Rusztem presented the Academy his father's manuscripts and books, about 660 works, among which 56 highly valuable Arabic, Persian and Turkish manuscripts can be found. Aurél Stein, a pioneer of Central Asian studies, sent the Academy part of his private library, 1112 books, as early as 1926, while the other parts reached the Library in the early 1950's. The Stein-library forms even today the core of materials related to Central Asia in the Oriental Collection. Sándor Kégl gave the Library his whole collection, i.e. 11000 works, among them 75 rarities, mostly Persian manuscripts. The extremely valuable correspondence of the scholar of 
Islamic studies, Ignác Goldziher, which contains 13600 items came into the possession of the Library in 1932. Several Tibetan, Manchurian and more than 150 Mongolian manuscripts and xylographies were donated to the Library.

In the last 25 years the Oriental Collection has gradually grown mainly by means of acquisitions and expanding international exchange. The number of books has been doubled, now totalling some 32000 items (about 44000 volumes), there are more than 800 periodicals, 500 of them being current ones. The necessary basic periodicals for oriental studies can be found in complete series. The number of manuscripts is as high as 5000 , and deserving special mention among them is the important Tibetan collection of 3000 items. An alphabetical catalogue gives information on the various materials.

The Oriental Collection consists of two communicating rooms. The first one is the reading room, built in Middle-Eastern style using motifs on the Islamic architecture, it accomodates 8 readers. The reference library in bookcases along the walls arranged by subject fields gives basic information on egyptology, Hebrew studies, Semitic philology, classical Middle-Eastern philology, Indian and Iranian studies, sinology, turcology, Tibetan and Islamic studies. The manuscripts, thus the Hebrew ones of the Kaufmann-collection, Turkish, Arabic and Persian ones of the Vámbéry and Kégl donations, the Körösi Csoma-collection, Mongolian and Manchurian manuscripts and xylographies are shelved in the inner room. This opens into a small chamber, where the most important periodicals can be found.

The Oriental Collection is well-known in international orientalism, and is frequently visited by foreign scholars for shorter or longer periods. It is regularly frequented by Hungarian orientalists of the present and the future, by university lecturers and students.

\section{Microfilm Collection and Reprographical Activities}

Reprographical activities of the Library of the Academy include photographic reproduction of its holdings, document copying, microfilming, the collection and use of microfilms. The Group of Microfilms and Photographic Laboratory of the Department of Reprography was set up in 1953. In 1958 UNESCO also contributed to its equipping. In the photographic laboratory up-to-date microfilm cameras, processors, printing machines and enlargers are at work. The laboratory and microfilm service can now engage in manifold work by means of equipment and cameras necessary for reading, copying and photoduplicating work of photographs of different types and sizes.

For the last 20 years the laboratory has regularly been making microfilm copies of the holdings of the Library, in the first place the most valuable or endangered materials of the Manuscript Department and the Oriental Collection, thus taking proper safety measures to preserve the holdings in case of emergency. Besides this it has extended microfilming to scientific institutions in the country and to ecclesiastical collections in order to preserve them and make them available for study. 
The microfilm collection has an important role in the increasing of the Library's stock. By means of exchange or purchase it can obtain microfilm copies of manuscripts and rarities that cannot be loaned. Between 1953 and 1975 the Library has acquired 2600 microfilms from 110 cities abroad, either in the form of purchase or on an exchange basis. A great number of these microfilms comprise manuscripts and works of literary history, linguistics, history, history of music and culture related to Hungary. At the end of 1975 the microfilm collection contained more than 15000 items. Considering that every film is copied for the purposes of reading and lending, the number of microfilms preserved is twice that mentioned above.

In the microfilm reading room of the Department the users may read their own microfilms besides those of the Library.

The collection of master-negatives contains an interesting source of the history of sciences, i.e. portraits of the Academy's members, writers, poets, reproductions of paintings, manuscripts, objects and buildings.

Since its establishment the laboratory has dealt with orders for microfilms and photocopies. It accepts orders for microfilms, $35 \mathrm{~mm}$ type reproductions, making roll-films and sheet-films, and their enlargements in different sizes.

The other group of the Department of Reprography is the Xerox Service, set up in 1968. At the beginning it worked with one machine, at present with several ones of heavy-duty type. On the one hand its task is to serve the Library by producing electrostatic-copies from books and periodicals for the Library's users, on the other hand to copy documents for the central administration of the Academy.

The electrostatic-copies given at reduced prices to the institutions, members, scholars and scientists of the Academy have become an essential condition of scientific work. They make possible the better exploitation of foreign specialized literature, the decreasing of their parallel acquisitions, expediting library administration. With its annual output of more than 1 million copies it is one of the largest document copying services in the country.

\section{Archives of the Academy}

The Archives of the Academy have been functioning since 1964 under the resolution no. 48/1963 of the Academy's Presidium. The resolution was a direct consequence of the historical tradition that the Academy itself preserves and reposits archivalia and documents related to its important efforts in science policy, scientific, cultural and science organization activities. The Presidium set up the Archives as an independent department of the Library of the Academy.

Its tasks are to preserve recent scientific documents, picture and voice material of the Academy's central administration and institutions, which are of historical value, to process the above material, and to perform the related administrative function. The preserved material is made available for scientific research and 
favourable conditions of research work are guaranteed by the Archives. The holdings of the Archives consist of the material of the Academy reorganized in 1949 and that of the latter's institutions from that time and have two parts: the internal and the external archival material. The internal one is that of the central administrative bodies of the Academy, while the external one includes that of the research institute network.

The purpose of the picture and voice material is to record and document the most important events of the Academy and activities related to scientific research. These materials are processed and preserved by the Archives and are available for research purposes and exhibitions of the history of sciences. The Archives regularly perform reference services. In its work it cooperates closely with other Hungarian archives and those of foreign academies. Connections are manifested by taking part in bilateral and multilateral works and in efforts made jointly with similar institutions. 
The tasks of the Group of Library Network and Methodology are the professional supervision of the libraries of the research centres, institutes and research groups of the Academy and the support of their work, directly serving research. The holdings of these institutional libraries represent a high intellectual value, not only because of their millions of books, but first of all because their holdings, which record the latest achievements in research, are used in a more intensive way than those of any large library, as they are available in the immediate vicinity of the scientists.

The library act (no. 1956/5 decree of legal force) made the Library of the Hungarian Academy of Sciences the centre of the research library network. The presidential instruction [13/1960 MTA, A. K. 20] dealing with the institutional library work created basic conditions for library work in 38 institutes of the Academy. Coordinating and supporting advisory activities of the Group were started simultaneously. Following the reorganization of the Academy an instruction of the Secretary-General [17/1972 (A. K. 20.) MTA-F] developed the library system in accordance with the increasing demands and with the use of accumulated methodological and practical experiences. The above instruction set the Group of Library Network and Methodology the task of assisting in matters of organizing, building and investing, of gathering and conveying experiences and new methods which are exploitable in institutional research libraries, of taking charge of training and extension training of librarians, of giving - as a professional advisory body - expert opinion about the basic problems of institutional libraries to the Academy's scientific departments, of recording and analyzing trends and new demands which emerge in library activities. The Group of Library Network and Methodology gives direct support to institutes by means of sending them publications received on international exchange basis, and through various services rendered (reprography, contents service, prints etc.).

In the appendix the institutional libraries are listed, with their stocks (statistical figures refer to 31 st December 1975.)

The institutional library network is in the possession of 659487 books, 263151 volumes of periodicals and approximately 340000 items of other documents (separates, research reports, maps, records, tapes, microfilms etc.) These stocks 


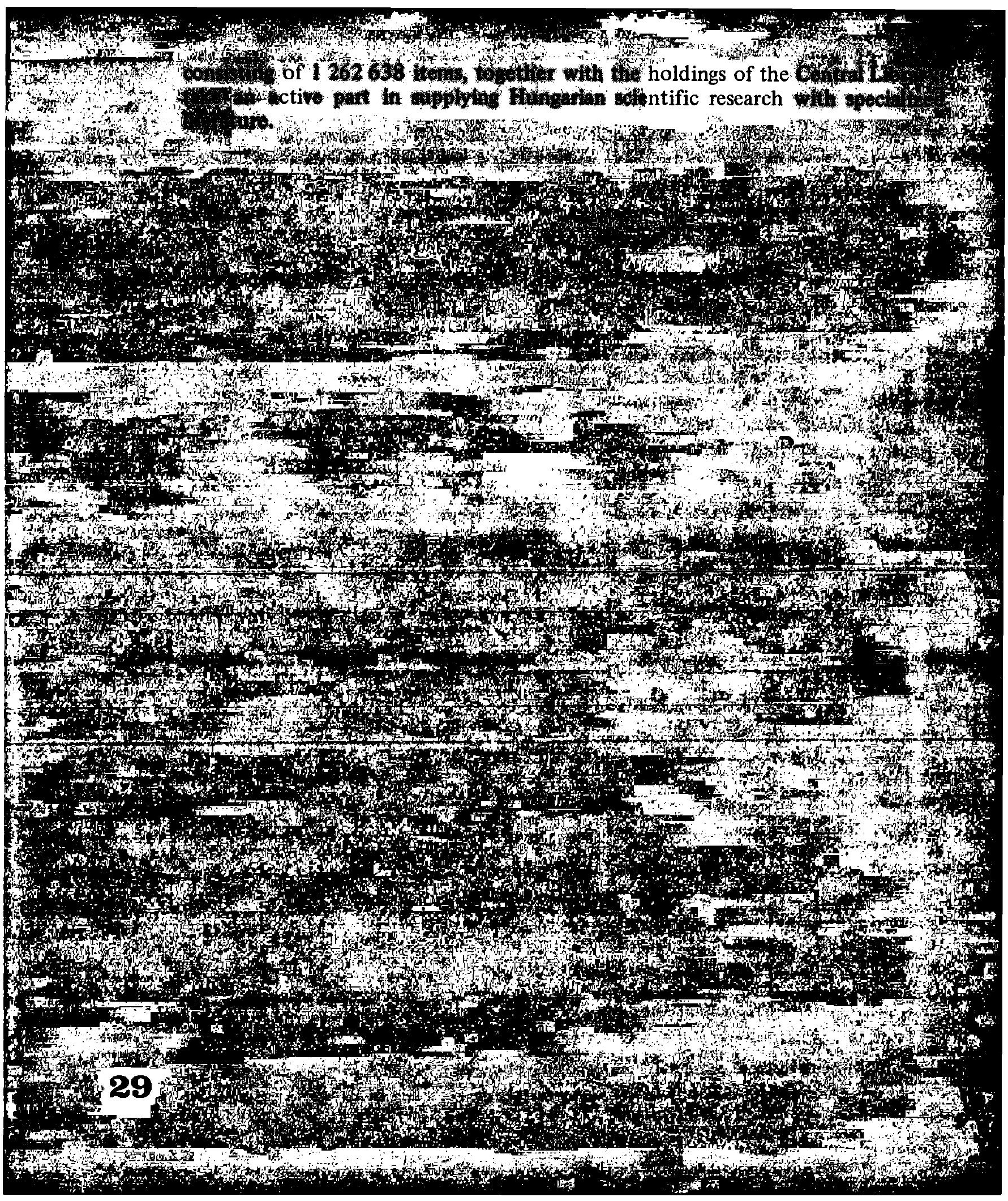




\section{RESEARCH LIBRARY NETWORK}

LIBRARY OF THE AGRICULTURAL RESEARCH INSTITUTE

Founded: 1950

Holdings: books: 11499 vols.

periodicals: 6120 vols.

LIBRARY OF THE BIOLOGICAL RESEARCH CENTER

Founded: 1971

Holdings: books: 5137 vols.

periodicals: 6385 vols.

LIBRARY OF THE BIOLOGICAL RESEARCH CENTER,

INSTITUTE OF BIOCHEMISTRY, DEPARTMENT OF ENZYMOLOGY

Founded: 1950

Holdings: books: 2552 vols.

periodicals: 3169 vols.

LIBRARY OF THE BIOLOGICAL RESEARCH INSTITUTE

Founded: 1927 (affiliated to the Academy since 1951)

Holdings: books: 5054 vols.

periodicals: 8867 vols.

LIBRARY OF THE CENTRAL RESEARCH INSTITUTE FOR CHEMISTRY

Founded: 1952

Holdings: books: 12190 vols. periodicals: 12976 vols. 
LIBRARY OF THE CENTRAL RESEARCH INSTITUTE FOR PHYSICS

Founded: 1950

Holdings: books: 47373 vols. periodicals: 13599 vols.

LIBRARY OF THE COMPUTER AND AUTOMATION INSTITUTE

Founded: 1960

Holdings: books: 21758 vols.

periodicals: 4508 vols.

LIBRARY OF THE ETHNOGRAPHICAL RESEARCH GROUP

Founded: 1967

Holdings: books: 11622 vols.

periodicals: 4910 vols.

LIBRARY OF THE GEOCHEMICAL RESEARCH LABORATORY

Founded: 1955

Holdings: books: 1555 vols.

periodicals: 46 vols.

LIBRARY OF THE GEODETICAL AND GEOPHYSICAL RESEARCH INSTITUTE

Founded: 1955

Holdings: books: 7853 vols.

periodicals: 3930 vols.

LIBRARY OF THE GEOGRAPHICAL RESEARCH INSTITUTE

Founded: 1951

Holdings: books: 25389 vols.

periodicals: 7918 vols.

LIBRARY OF THE GEOGRAPHICAL RESEARCH INSTITUTE, LOWLAND UNIT

Founded: 1973

Holdings: books: $\quad 985$ vols.

periodicals: $\quad 300$ vols.

LIBRARY OF THE GROUP FOR SCIENCE ORGANIZATION

Founded: 1968

Holdings: books: 1136 vols.

periodicals: 364 vols. 
Founded: 1958

Holdings: books: 1805 vols.

periodicals: 3919 vols.

LIBRARY OF THE INSTITUTE FOR ARCHAEOLOGY

Founded: 1959

Holdings: books: $\quad 8736$ vols. periodicals: 3433 vols.

LIBRARY OF THE INSTITUTE OF ECONOMICS

Founded: 1955

Holdings: books: 29658 vols. periodicals: 4965 vols.

LIBRARY OF THE INSTITUTE OF EXPERIMENTAL MEDICINE

Founded: 1954

Holdings: books: 4521 vols.

periodicals: 8817 vols.

LIBRARY OF THE INSTITUTE OF HISTORY

Founded: 1941 (affiliated to the Academy since 1951)

Holdings: books: 71408 vols.

periodicals: 16497 vols.

LIBRARY OF THE INSTITUTE OF ISOTOPES

Founded: 1959

Holdings: books: $\quad 7598$ vols. periodicals: 2145 vols.

LIBRARY OF THE INSTITUTE FOR LEGAL AND ADMINISTRATIVE SCIENCES

Founded: 1950

Holdings: books: 28962 vols.

periodicals: 11881 vols.

LIBRARY OF THE INSTITUTE OF LINGUISTICS

Founded: 1950

Holdings: books: 21973 vols. periodicals: 5805 vols. 
LIBRARY OF THE INSTITUTE OF LITERARY STUDIES (EOTVOUS LIBRARY)

Founded: 1895 (affiliated to the Academy since 1956)

Holdings: books: 113259 vols. periodicals: 15512 vols.

LIBRARY OF THE INSTITUTE FOR MUSICOLOGY

Founded: 1974

Holdings: books: 13539 vols. periodicals: 4741 vols.

LIBRARY OF THE INSTITUTE OF NUCLEAR RESEARCH

Founded: 1954

Holdings: books: $\quad 8335$ vols.

periodicals: 10186 vols.

LIBRARY OF THE INSTITUTE OF PHILOSOPHY

Founded: 1957

Holdings: books: 11447 vols. periodicals: 1064 vols.

LIBRARY OF THE INSTITUTE OF PHILOSOPHY, LUKĀCS ARCHIVES AND LIBRARY

Founded: 1971

Holdings: books: $\quad 9852$ vols.

LIBRARY OF THE INSTITUTE OF PSYCHOLOGY

Founded: 1902 (affiliated to the Academy since 1953)

Holdings: books: 9100 vols.

periodicals: 1024 vols.

LIBRARY OF THE INSTRUMENTS AND MEASURING TECHNIQUE SERVICE

Founded: 1959

Holdings: books: 1769 vols.

periodicals: $\quad 800$ vols.

LIBRARY OF THE KONKOLY OBSERVATORY

Founded: 1921 (affiliated to the Academy since 1951)

Holdings: books: 9369 vols.

periodicals: 16404 vols. 
LIBRARY OF THE MATHEMATICAL RESEARCH INSTITUTE

Founded: 1950

Holdings: books: 33065 vols. periodicals: 31823 vols.

LIBRARY OF THE MICROBIOLOGICAL RESEARCH GROUP

Founded: 1963

Holdings: books: 1149 vols.

periodicals: 1955 vols.

LIBRARY OF PETROLEUM ENGINEERING RESEARCH LABORATORY

Founded: 1957

Holdings: books:

3453 vols. periodicals: $\quad 946$ vols.

LIBRARY OF THE RESEARCH GROUP FOR ART HISTORY

Founded: 1969

Holdings: books: 15632 vols. periodicals: 2609 vols.

LIBRARY OF THE RESEARCH GROUP FOR EDUCATION

Founded: 1952

Holdings: books:

2909 vols. periodicals: $\quad 450$ vols.

LIBRARY OF THE RESEARCH INSTITUTE FOR BOTANY

Founded: 1972

Holdings: books: $\quad 3559$ vols. periodicals: 2907 vols.

LIBRARY OF THE RESEARCH INSTITUTE FOR INDUSTRIAL ECONOMICS

Founded: 1960

$\begin{array}{lr}\text { Holdings: books: } & 3145 \text { vols. } \\ \text { periodicals: } & 258 \text { vols. }\end{array}$

LIBRARY OF THE RESEARCH INSTITUTE FOR SOIL SCIENCE AND AGRICULTURAL CHEMISTRY

Founded: 1949 (affiliated to the Academy since 1955)

Holdings: books: 10841 vols.

periodicals: 10675 vols. 
LIBRARY OF THE RESEARCH INSTITUTE OF TECHNICAL CHEMISTRY

Founded: 1960

Holdings: books:

4283 vols.

periodicals: $\quad 864$ vols.

LIBRARY OF THE RESEARCH INSTITUTE FOR TECHNICAL PHYSICS

Founded: 1958

Holdings: books: 10458 vols.

periodicals: 5853 vols.

LIBRARY OF THE RESEARCH INSTITUTE FOR WORLD ECONOMY (Reference Service)

Founded: 1966

Holdings: books: 22296 vols.

periodicals: 1164 vols.

LIBRARY OF THE SOCIOLOGICAL RESEARCH INSTITUTE

Founded: 1963

Holdings: books: 4676 vols.

periodicals: $\quad 971$ vols.

LIBRARY OF THE TRANSDANUBIAN SCIENTIFIC INSTITUTE

Founded: 1943 (affiliated to the Academy since 1955)

Holdings: books: 17518 vols.

periodicals: 4744 vols.

LIBRARY OF THE VETERINARY SCIENCE RESEARCH INSTITUTE

Founded: 1950

Holdings: books: 2320 vols.

periodicals: 3436 vols.

"LIBRARY OF THE HUNGARIAN GEOGRAPHICAL SOCIETY

Founded: 1872 (under the supervision of the Academy's Library since 1950) Holdings: books: 16249 vols. periodicals: 11211 vols.

*LIBRARY OF THE HUNGARIAN NUMISMATIC SOCIETY

Founded: 1902 (under the supervision of the Academy's Library since 1970) Holdings: books: 2500 vols. periodicals: 3000 vols.

*The libraries of these learned societies were affiliated to the institutional network of the Academy in accordance with the instruction of the Secretary-General in 1972. In recent years full-time librarians have been in charge of the valuable stocks. 


\section{Publications of the Library of the Hungarian Academy of Sciences}

(Publicationes Bibliothecae Academiae Scientiarum Hungaricae)

1. Haraszthy Gyula: A 130 éves Akadémiai Könyvtár.

Bp. 1956. 23 p. [The 130th anniversary of the Academy's Library]

2. Berlász Jenö - Sz[akmáryné] Németh Mária: Az Akadémiai Könyvtár múltja és jelene. Bp. 1956. 30 p. [The past and present of the Academy's Library]

3. Csapodi Csaba: A legrégibb magyar könyvtár belső rendje. A pannonhalmi könyvtár a XI. században. Bp. 1957. 13 p. [The internal order of the oldest Hungarian library. The library of Pannonhalma in the 11 th century]

4. Berlász Jenó: Az Akadémiai Könyvtár kézirattárának átalakulása. Bp. 1957. 21 p. [The reorganization of the Manuscript Department of the Academy's Library]

5. Haraszthy Gyula: Az Országos Könyvtárügyi Tanács és a magyar könyvtárügy időszerü kérdései. Bp. 1958. 16 p. [The National Council of Librarianship and the current problems of Hungarian libraries]

6. Gergely Pál: Arany János és az Akadémia Könyvtára. Bp. 1958. 8 p. [János Arany and the Academy's Library]

7. Moravek, Endre: Die neuen ungarischen Bibliotheksnormen. Wien, 1957.16 p.

8. Sz[akmáryné] Németh Mária: Az Akadémiai Könyvtár, mint a Magyar Tudományos Akadémia célkitüzéseinek könyvtári támogatója. Bp. 1958. 14 p. [The Library of the Hungarian Academy of Sciences in the service of the aims of the Academy]

9. Gergely Pál: Az Akadémia levéltára a Magyar Tudományos Akadémia Könyvtárának kézirattárában. Bp. 1958. 11 p. [The Archives of the Hungarian Academy of Sciences]

10. Csapodi Csaba: Könyvkonzerválás és restaurálás a Magyar Tudományos Akadémia Könyvtárában. Bp. 1958. 18 p. [Conservation and restauration of old books in the Library of the Hungarian Academy of Sciences]

11. Moravek Endre: Kiadványtípusok a katalogizálás szempontjából. Bp. 1958.

$12 \mathrm{p}$. [Types of publications from the point of view of cataloguing]

12. Sz[akmáryné] Németh Mária: A központi folyóirat címjegyzék kérdései. Bp. 1959. 44 p. [On the problems of union lists of periodicals]

13. Csapodi, Csaba: L'avenir des périodiques scientifiques. La Haye, 1958. [2] p.

14. F[ülöpné] Csanak Dóra: Az Akadémiai Könyvtár története a szabadságharcig. 1826-1849. Bp. 1959. 29 p. [History of the Library of the Hungarian Academy of Sciences 1826-1849]

15. Moravek, Endre - Weger, Imre: Kratkii slovar' vengerskikh bibliograficheskikh terminov i sokrashchenii. Bp. 1959.48 p.

16. Csapodi, Csaba: Der geographische Begriff im Katalogsystem der Bibliothek. Wien, 1959. $11 \mathrm{p}$. 
17. Csapodi Csaba: A proveniencia elve a könyvtárban. Bp. 1959. 14 p. [The principle of provenience in the library]

18. Rásonyi László: Stein Aurél és hagyatéka. Bp. 1960. 40 p. 1 t. [Sir Aurel Stein and his legacy]

19. Sáfrán Györgyi: Arany János és Rozvány Erzsébet. Bp. 1960.178 p. 11 t. [János Arany and Erzsébet Rozvány]

20. Rózsa György: A magyar társadalomtudományok az UNESCO kiảdványaiban - Les sciences sociales hongroises dans les publications de l'UNESCO. Bp. 1960. $19 \mathrm{p}$.

21. Gergely Pál: Pápai Páriz-album a Magyar Tudományos Akadémia Könyvtárában. Bp. 1961. 9 p. [The Pápai Páriz album in the Library of the Hungarian Academy of Sciences]

22. Gergely Pál: Bartók Béla ismeretlen levelei a Tudományos Akadémia Könyvtárában. Bp. 1961.15 p. [Unknown letters of Béla Bartók in the Library of the Hungarian Academy of Sciences]

23. Sarlóska Vince Ernö: Bolyai János házassága a köztudatban és a dokumentumok. Bp. 1961. 14 p. [What was known about the marriage of János Bolyai and the related documents]

24. Csapodi Csaba: Mikor pusztult el Mátyás király könyvtára? Bp. 1961. 25 p. [When was the library of king Matthias destroyed?]

25. Moravek, Endre - Weger, Imre: Abbreviaturae cyrillicae. Bp. 1961. 138 p.

26. Rásonyi László: A magyar keletkutatás orosz kapcsolatai. Bp. 1962. 19 p. [Russian connections of Hungarian oriental studies]

27. Tökés László: Az Akadémiai Könyvtár mikrokönyvgyüjteménye és fotolaboratóriuma. Bp. 1962. 13 p. [The micro-library and photographic laboratory at the Library of the Hungarian Academy of Sciences]

28. Fráter Jánosné: „Nemzeti részvét emelte”. 100 évvel ezelôtt kezdték épiteni az Akadémia palotáját. Bp. 1962. 14 p. [100 years since the construction of the Hungarian Academy of Sciences' building was begun]

29. Büky Béla: Székely Bertalan hagyatéka a Magyar Tudományos Akadémia Könyvtárában. Bp. 1962. 24 p. [The literary remains of Bertalan Székely in the Manuscript Department of the Library of the Hungarian Academy of Sciences]

30. Moravek, Endre: Index acronymorum selectorum. Pars 2. Instituta scientifica. Bp. 1962. VI, 278 p.

31. Méreiné Juhász Margit: Mikszáth Kálmán 'szellemi és tárgyi hagyatéka a Magyar Tudományos Akadémián és tájmúzeumainkban. Bp. 1963. 65 p. [The objects and literary remains of Kálmán Mikszáth at the Hungarian Academy of Sciences and in the Hungarian provincial museums]

32. Rózsa, (György) George: The documentation of science organization as an emerging new branch of scientific information. Bp. 1962.13 p.

33. Gergely Pál - Molnár Zoltán: Az Akadémiai Értesítő és a Magyar Tudomány repertóriuma. 1840-1960. Bp. 1962. VI, 377 p. [The repertory of the periodicals 'Akadémiai Ertesítő' and 'Magyar Tudomány' 1840-1960] 
34. Csapodi Csaba: Mikor szünt meg Mátyás király könyvfestő mühelye? Bp. 1963. 18 p. [When did king Matthias' workshop of illuminators cease to work?]

35. Tókés László: A mikrokártya és a kutatók. Bp. 1963. 18 p. [The microcard and the researchers]

36. Büky Béla - Csengeryné Nagy Zsuzsa: Székely Bertalan illusztrációi egy tervezett Petőfi-életrajzhoz. Bp. 1963. 15 p. [The Bertalan Székely's illustrations for a planned Petőfi-biography]

37. Gergely Pál: Az Akadémia szerepe a Nemzeti Színház létrehozásában. Bp. 1963. 9 p. [The role of the Hungarian Academy in establishing the National Theatre of Pest]

38. Moravek, Endre: Index acronymorum selectorum. Pars 3. Instituta paedagogi ca. Bp. 1963. VI, 377 p.

39. György, [József] Josef: Die Goethe-Sammlung Balthasar Elischers in der Bibliothek der Ungarischen Akademie der Wissenschaften. Bp. 1963.29 p. 40. Rózsa György: Részvételünk és lehetőségek a nemzetközi társadalomtudományi dokumentációban. Bp. 1964. 17 p. [Our participation and possibilities in international social science documentation work]

41. Csapodi Csaba: Beatrix királyné könyvtára. Bp. 1964. 26 p. [The library of queen Beatrice]

42. Rózsa György: Hagyomány és korszerûség: az Akadémiai Könyvtár távlati fejlesztéséról. Bp. 1964. 13 p. [Tradition and up-to-dateness: on the longrange development of the Academy's Library]

43. Büky Béla: A tudományos tájékoztatás egyik feladatköre: témamegoszlási statisztikák készítése és alkalmazása. Bp. 1964.16 p. [One task of supplying scientific information: preparation and application of theme-analysing statistics]

44. Csapodi, Csaba: Conservation of the manuscript and old book collections at the Library of the Hungarian Academy of Sciences: methods and results. (1949-1964). Bp. 1965.48 p. 16 t.

45. Fráter Jánosné: Részletek az Akadémiai Könyvtár történetébool. (1865-1875). Bp. 1965. 59 p. 7 t. [A period of the history of the Academy's Library. (1865-1875)]

46. Moravek, Endre: Index acronymorum selectorum. Pars 1. Instituta rerum publicarum. Bp. $1965.621 \mathrm{p}$.

47. Moravek, Endre: Index acronymorum selectorum. Pars 7. Instituta communicationis. Bp. 1966. XXII, 355 p.

48. Sáfrán, Györgyi: Lettres de Romain Rolland à Marianne Czeke dans la Bibliothèque de l'A cadémie des Sciences de Hongrie. Bp. 1966. 195 p. 4 t.

49. Moravek, Endre: Index acronymorum selectorum. Pars 4. Religio. Bp. 1966. XVIII, $211 \mathrm{p}$.

50. Rózsa, [György] George: Some considerations of the role of scientific libraries in the age of the scientific and technical revolution. An essay and approach to the problem. Bp. $1970.25 \mathrm{p}$. 
51. Simon Mária Anna: A Magyar Tudományos Akadémia kuţatóintézeti könyvtári hálózata. Bp. 1966. 52 p. [The research library network of the Hungarian Academy of Sciences]

52. Fráter Jánosné: A Magyar Tudományos Akadémia Történettudományi Bizottságának müködése $1854-1949$. Bp. 1966. 61 p. 3 t. [The activities of the Committee on History of the Hungarian Academy of Sciences]

53. Csapodi Csaba: A Magyar Tudományos Akadémia Könyvtárának ósnyomtatvány-gyüjteménye. Bp. 1967. 34 p. [The collection of incunabula in the Library of the Hungarian Academy of Sciences]

54. H[aranginé $]$ Boros Vilma: Széchenyi István hátrahagyott iratainak története. Bp. 1967. 57 p. 5 t. [The history of the literary remains of István Széchenyi]

55. György József: Az Akadémia Könyvtára egykori Goethe-szobája és nevesebb magyar látogatói. Bp. 1968. 25 p. [The quondam Goethe room of the Academy's Library and its famous visitors]

56. Bükyné Horváth Mária: Az Akadémiai Könyvtár kurrens külföldi periodikumai. Bp. 1968. 50 p. [Current foreign periodicals of the Academy's Library]

57. Moravek, Endre: Index acronymorum selectorum. Pars 6.Instituta oeconomica. Bp. 1969. XIX, 556 p.

58. Szelei László: A Magyar Tudományos Akadémia Levéltára az Akadémiai Könyvtárban. Bp. 1970. 60 p. [The Archives of the Hungarian Academy of Sciences in the Academy's Library]

59. Sz[abóné] Garai Judit - Ujhelyi Gabriella: A Magyar Tudományos Akadémia Könyvtára orosz és szovjet cserekapcsolatainak vázlatos története. - Ocherki istorii knigoobmena Biblioteki Vengerskoi Akademii Nauk s russkimi sovetskimi bibliotekami. Bp. 1970.46 p.

60. Molnár Imre: Peremlyukkártyás dokumentációs rendszerek létesítése kutatóintézeti könyvtárban. Bp. 1970. 134 p. [Edge notched card systems for research library documentation]

61. H[aranginé] Boros Vilma: Stein Aurél ifjúsága. Hirschler Ignác és Stein Ernö levelezése Stein Aurélról. 1866-1891. Bp. 1971. 148 p. [Aurel Stein's youth. Correspondence of Ignatius Hirschler and Ernest Stein about Aurel Stein. 1866-1891]

62. Apor, Eve: The Persian manuscript of the Vámbéry-bequest. Bp. 1971.19 p. $1 \mathrm{t}$.

63. Gergely Pál: A Magyar Tudományos Akadémiára hagyott Vigyázó-vagyon sorsa. Bp. 1971.97 p. 8 t. [Thı circumstances of the Vigyázó estates bequeathed to the Hungarian Academy of Sciences]

64. Moravek, Endre: Index acronymorum selectorum. Pars 8. Instituta sanitatis publicae. Instituta caritatis. Instituta varii generis. Bp. 1971. XXI, 559 p.

65. Bükyné Horváth Mária: Az Akadémiai Könyvtár periodikumai a tudományos kutatás szolgálatában. Bp. 1971. 232 p. 2 t. [Periodicals of the Academy's Library concerning scientific research]

66. Moravek, Endre: Index acronymorum selectorum. Pars 5. Instituta ad artes litteraturamque spectantia cum siglis periodicorum additis. Bp. 1972. XIX, 39477 . 
67. Vitályos László - Orosz László: Ady-bibliográfia 1896-1970. Ady Endre önállóan megjelent müvei és az Ady-irodalom. Bp. 1972. XXV, 425 p. [Ady bibliography 1896-1970. The works of Endre Ady published separately and the Ady-bibliography]

68. Botka Ferenc: Magyar szocialista irodalom oroszul 1921-1945. Bibliográfia. - Vengerskaya sotsialisticheskaya literatura na russkom yazyke 1921-1945 gg. Bibliograficheskii obzor. Bp. 1972. XIII, 127 p. 9 t.

69. Szentgyörgyi Mária: Célkitüzések és reformtörekvések a Magyar Tudományos Akadémián. 1831-1945. Bp. 1973. 170 p. [Aims and reform endeavours of the Hungarian Academy of Sciences from 1831 to 1945]

70. Fráter Jánosné: A Magyar Tudományos Akadémia állandó bizottságai. 1854-

1949. Bp. 1974. 430 p. [The permanent committees of the Hungarian Academy of Sciences. 1854-1949]

71-72. in preparation

73. Az Akadémiai Ertesítô és a Magyar Tudomány indexe 1840-1970. A-L. Szerk. Darabos Pál és Domsa Károlyné. Bp. 1975. 473 p. [Index of the periodicals 'Akadémiai Ertesítô' and 'Magyar Tudomány' 1840-1970]

74. Az Akadémiai Értesítô és a Magyar Tudomány indexe 1840-1970. M-R. Szerk. Darabos Pál és Domsa Károlyné. Bp. 1975. 475-846. p. [Index of the periodicals 'Akadémiai Ertesítő' and 'Magyar Tudomány' 1840-1970]

75. Az Akadémiai Ertesítő és a Magyar Tudomány indexe 1840-1970. S-Z. Repertórium 1840-1970. Szerk. Darabos Pál és Domsa Károlyné. A repertóriumot összeáll. Pétervári Lászlóné és Sz[abóné] Garai Judit. Bp. 1975. 847-1242. p. [Index of the periodicals 'Akadémiai Ertesíto’' and 'Magyar Tudomány' 1840-1970. Repertory. 1840-1970]

\section{Catalogues of the Manuscript Department of the Library of the Hungarian Academy of Sciences}

(Catalogi Collectionis Manuscriptorum Bibliothecae Academiae Scientiarum Hungaricae)

1. F[ülöpné] Csanak Dóra: Balázs Béla hagyatéka az Akadémiai Könyvtár Kézirattárában. (Ms 5009 - Ms 5024). Bp. 1966.95 p. 5 t. [The literary remains of Béla Balázs at the Manuscript Department of the Academy's Library]

2. Rejtö István: Zalka Máté kéziratos hagyatéka. (Ms 4796 - Ms 4806). Bp. 1966. 49 p. [The manuscripts of Máté Zalka]

3. F|ülöpné] Csanak Dóra: Vörösmarty Mihály-levelezés, Csokonai Vitéz Mihálylevelezés, Ady Endre-gyüjtemény. (K 1 - K 21). Bp. 1967. 199 p. 4 t. [Catalogues of the correspondence of M. Vörösmarty, correspondence of M. Csokonai Vitéz and the Ady-collection]

4. Fráter Jánosné: A Bolyai-gyüjtemény. (K 22 - K 30). Bp. 1968. 119 p. 8 t. [The Bolyai-collection] 
5. Csapodi Csaba: A „Magyar Codexek” elnevezésũ gyüjtemény. (K 31 - K 114). Bp. 1973. 133 p. [The collection of the so called 'Hungarian Codices']

6. F[ülöpné] Csanak Dóra: Szabó Lörinc kéziratos hagyatéka.·(Ms 6450 - Ms 7405). Bp. 1973. 309 p. [The catalogue of the manuscripts of Lőrinc Szabó]

7. Marth Hildegard: A Goethe-gyûjitemény. (K 115 - K 124). Bp. 1974. 130 p. 6 t. [The Goethe-collection]

8. Marth Hildegard: A Gábor Andor-hagyaték. (Ms 4456 - Ms 4500). Bp. 1974. 166 p. [The literary remains of Andor Gábor]

\section{Catalogues of dissertations}

Kandidátusi és doktori disszertációk katalógusa.

1952-1961. [1. rész]. Szerk. Csapodi Csaba és Gergely Pál. Bp. 1962. IV, 183 p. [The catalogue of dissertations of 'candidatus scientiarum' and 'doctor scientiarum'. 1952-1961]

Kandidátusi és doktori disszertációk katalógusa.

1962-1963. [2. rész]. Szerk. Fráter Jánosné és Hajnal Gáspár. Bp. 1965. 87 p. [The catalogue of dissertations of 'candidatus scientiarum' and 'doctor scientiarum'. 1962-1963]

Kandidátusi és doktori disszertációk katalógusa. 1964-1965. 3. rész.

Szerk. Fráter Jánosné, Hajnal Gáspár és Markovits Pálné. Bp. 1967. 85 p. [The catalogue of dissertations of 'candidatus scientiarum' and 'doctor scientiarum'. 1964-1965]

Kandidátusi és doktori disszertációk katalógusa. 1966-1967. 4. rész.

Szerk. Hajnal Gáspár, Markovits Pálné és Maróth Miklós. Bp. 1969. 95 p. [The catalogue of dissertations of 'candidatus scientiarum' and 'doctor scientiarum'. 1966-1967]

Kandidátusi és doktori disszertációk katalógusa. 1968-1970. 5. rész.

Szerk. Woitilla Gyula. Bp. 1972. X, 137 p. [The catalogue of dissertations of 'candidatus scientiarum' and 'doctor scientiarum'. 1968-1970]

\section{Micropublications of the Library of the Hungarian Academy of Sciences}

1. Ferenczy Endre: Bevezetés az ékírásos jogtörténetbe. Bibliográfia. Bp. 1962.5 mikrolap. [Introduction to the history of cuneiform law. A bibliography]

2. Vajda, Pál: Hungarian pioneers in electrical engineering. Bp. 1963. 2 microfiches.

3. Hazai, György: Ármin Vámbéry 1832-1913. A bio-bibliography. Bp. 1963. 1 microfiche.

4. Vajda, Pál: History of the transformer. Bp. 1964. 3 microfiches.

5. Vajda, Pál: Hungarian bridges and bridge builders. Bp. 1964. 4 microfiches.

6. [Dezsö] Dezhe, L[ászló]: Materialy k slovarju zakarpatskoi literatury XVI41 XVII. vv. Bp. 1965. 16 mikrokartochek. 
Tudományszervezési Tájékoztató 1961 - (évenként 6 szám) [Bulletin of Science Organization, a bi-monthly journal]

[Magyar Tudományos Akadémia. Könyvtár]. Kurrens külföldi periodikus kiadványok jegyzéke. Összeáll. Bükyné Horváth Mária. Bp. 1960. 517 p. Soksz.

Suppl. 1. Bp. 1962. 211 p. Soksz.

Suppl. 2. Bp. 1966. 261 p. Soksz.

[Hungarian Academy of Sciences. The Library. A list of current foreign periodicals]

[Magyar Tudományos Akadémia. Könyvtár]. Kurrens külföldi periodikus kiadványok jegyzéke. Összeáll. Bánhegyi Zsolt, Bükyné Horváth Mária stb. Bp. 1973. VII, 595 p. [Hungarian Academy of Sciences. The Library. A list of current foreign periodicals.]

Kurrens külföldi periodikus kiadványok az akadémiai intézeti könyvtárakban. Ósszeáll. Büky Béláné és Fekete Györgyné, Weger Imre közremüködésével. Bp. 1964. IX, $525 \mathrm{p}$. Soksz. [Current foreign periodicals in the institutional libraries of the Academy. A census.]

A Magyar Tudományos Akadémia Könyvtára Ưj Külföldi Gyarapodásainak Jegyzéke. 1972- (évenként 6 szám) Soksz. [The list of recent foreign acquisitions of the Library of the Hungarian Academy of Sciences. Published bimonthly since 1972]

A megújhodott Magyar Tudományos Akadémia. 1949-1953. Bibliográfia. Bp. 1954. 156 p. Soksz. [The renewed Hungarian Academy of Sciences. 19491953. A bibliography]

A Magyar Tudományos Akadémia müködése. 1954. Bibliográfia. Bp. 1955. 137 p. Soksz. [The activities of the Hungarian Academy of Sciences. 1954. A bibliography]

A Magyar Tudományos Akadémia müködése. 1955. Bibliográfia. Bp. 1956. 308 p. Soksz. [The activities of the Hungarian Academy of Sciences. 1955. A bibliography]

Radioaktív izotópok. Bibliográfia a magfizikai alapfogalmak, a mérési módszerek, az egészségvédelmi eszközök, valamint néhány területen történő alkalmazás tanulmányozásához. Ósszeáll. Földes Endre. Bp. 1954. 25 p. Soksz. [Radioisotopes. A bibliography for the study of nuclear elements, measuring procedures, means of protecting health, and their applications on certain fields]

Az atomenergia békés felhasználása. Bibliográfia. Bp. 1955. 296 p. Soksz. [Peaceful uses of atomic energy. A bibliography]

A Magyar Tudományos Akadémia Könyvtára 1826-1961. Szerk. Rózsa György irányításával Csapodi Csaba, Moravek Endre [stb.] Bp. 1960. 109 p.

The Library of the Hungarian Academy of Sciences 1826-1961. Ed. by G[yörgy] Rózsa with the collab. of C[saba] Csapodi, E[ndre] Moravek [etc.]Bp. 1960. $99 \mathrm{p}$. 
Biblioteka Vengerskoi Akademii Nauk 1826-1961. Pod red. G[yörgy] Rózsa. Sost. I[mre Weger] Veger, E[ndre] Moravek [i dr.] Bp. 1960. 101 p.

Idegennyelvŭ pszichológiai müvek könyvtárainkban. 1950-1960. Bibliográfia. Összeáll. az MTAK Bibl. Oszt. Bp. 1961. 155 p. Soksz. (Közös kiadás az MTA Pszichológiai Bizottságával.) [Publications on psychology in foreign languages in Hungarian libraries 1950-1960. A bibliography]

Hungarian publications on Asia and Africa. 1950-1962. A selected bibliography. Compil. by Eva Apor - Ildikó Ecsedy. Bp. 1963. 106 p.

A magyar szakirodalom külföldi referáltsága. (Kémia, biológia, orvostudomány). Összeáll. Varga Veronika - Rátz Erzsébet - Dörnyei Sándor. Bp. 1964. 85 p. Soksz. [Foreign abstracts of Hungarian scientific literature. Chemistry, Biology, Medicine]

A Magyar Tudományos Akadémia tagjai 1825-1973. Ósszeáll. Fekete Gézáné. Bp. 1975. XII, 609 p. [Members of the Hungarian Academy of Sciences 18251973.]

Bartoniek Emma: Fejezetek a XVI-XVII. századi történetírás történetéből. Sajtó alá rend. Ritoók Zsigmondné. Kézirat gyanánt. Bp. 1975. 586 p. (Közös kiadás az MTA Irod. tud. Intézetével.) [Outlines of the history of historiography in the 16 th and 17 th century] 



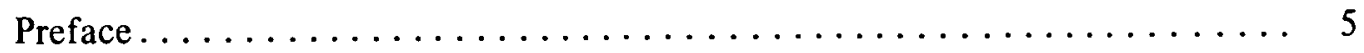

I. Historical outline $\ldots \ldots \ldots \ldots \ldots \ldots \ldots \ldots \ldots \ldots \ldots$

II. The work and use of the Library $\ldots \ldots \ldots \ldots \ldots \ldots \ldots \ldots \ldots$

Acquisitions policy, international exchange, holdings $\ldots \ldots \ldots \ldots \ldots 16$

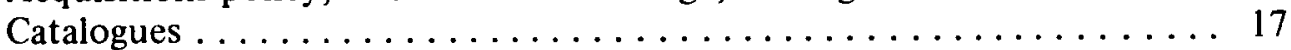

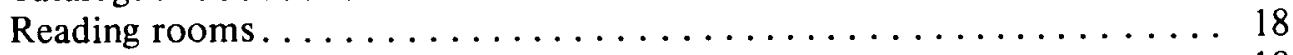

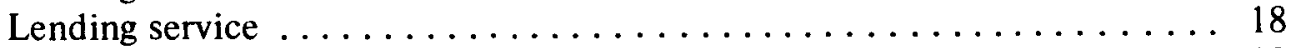

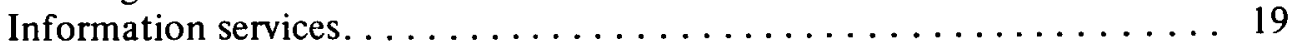

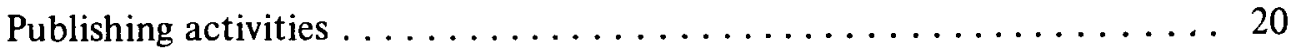

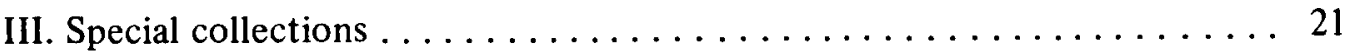

Periodicals Department . . . . . . . . . . . . . . . . . 21

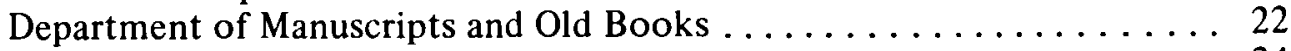

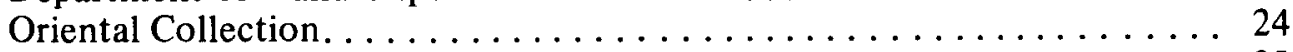

Microfilm Collection and reprographical activities . . . . . . . . 25

Archives of the Academy . . . . . . . . . . . . . . . . 26

IV. Network and methodological work $\ldots \ldots \ldots \ldots \ldots \ldots \ldots$

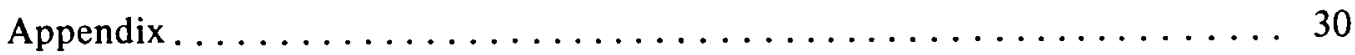

Research library network .................... 30

Bibliography of works published by the Library ............ 36

Illustrations . . . . . . . . . . . . . . . . . . . . . . . . . . 47 


\section{ILLUSTRATIONS}



The building of the Academy in the last century 


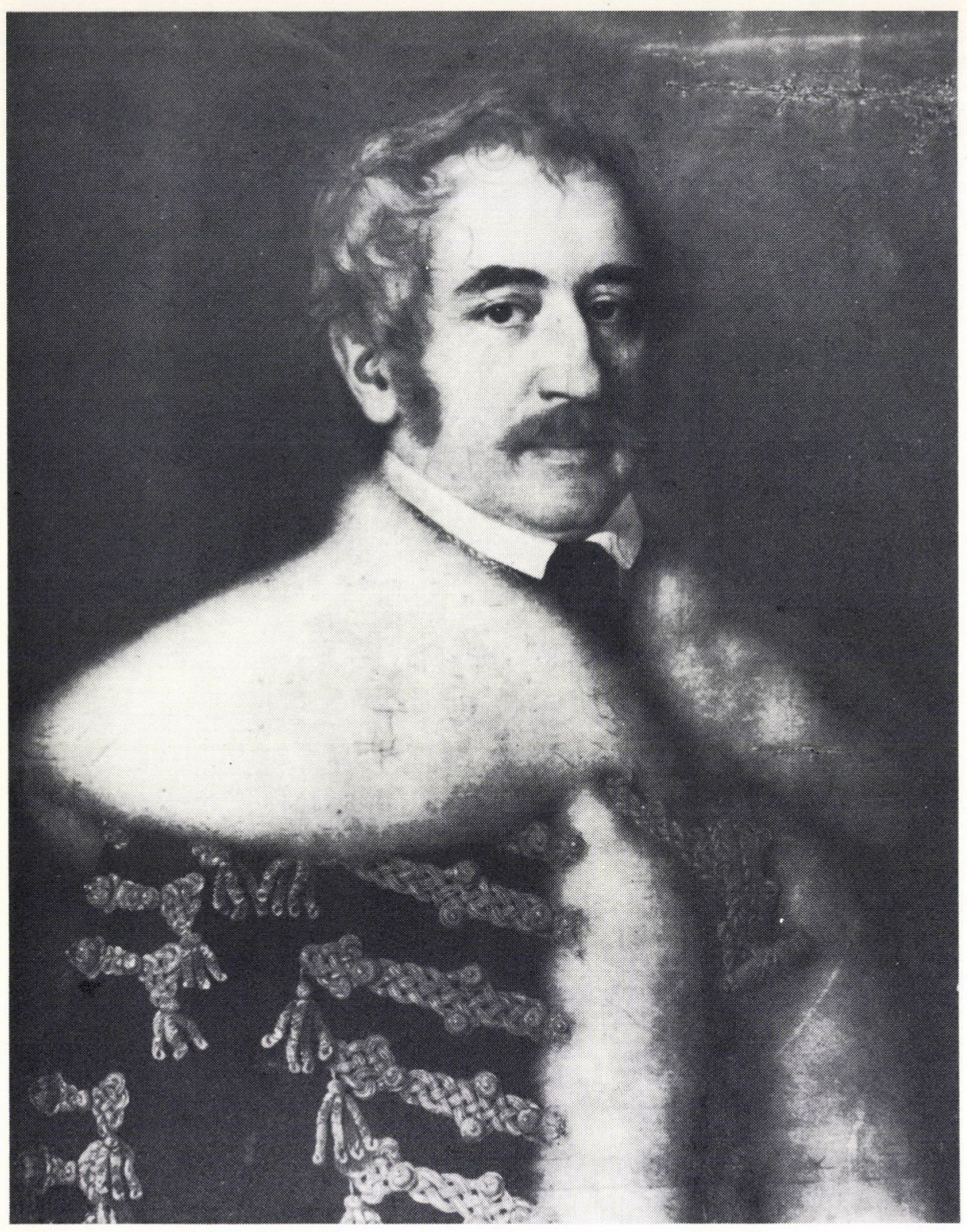

Count József Teleki 


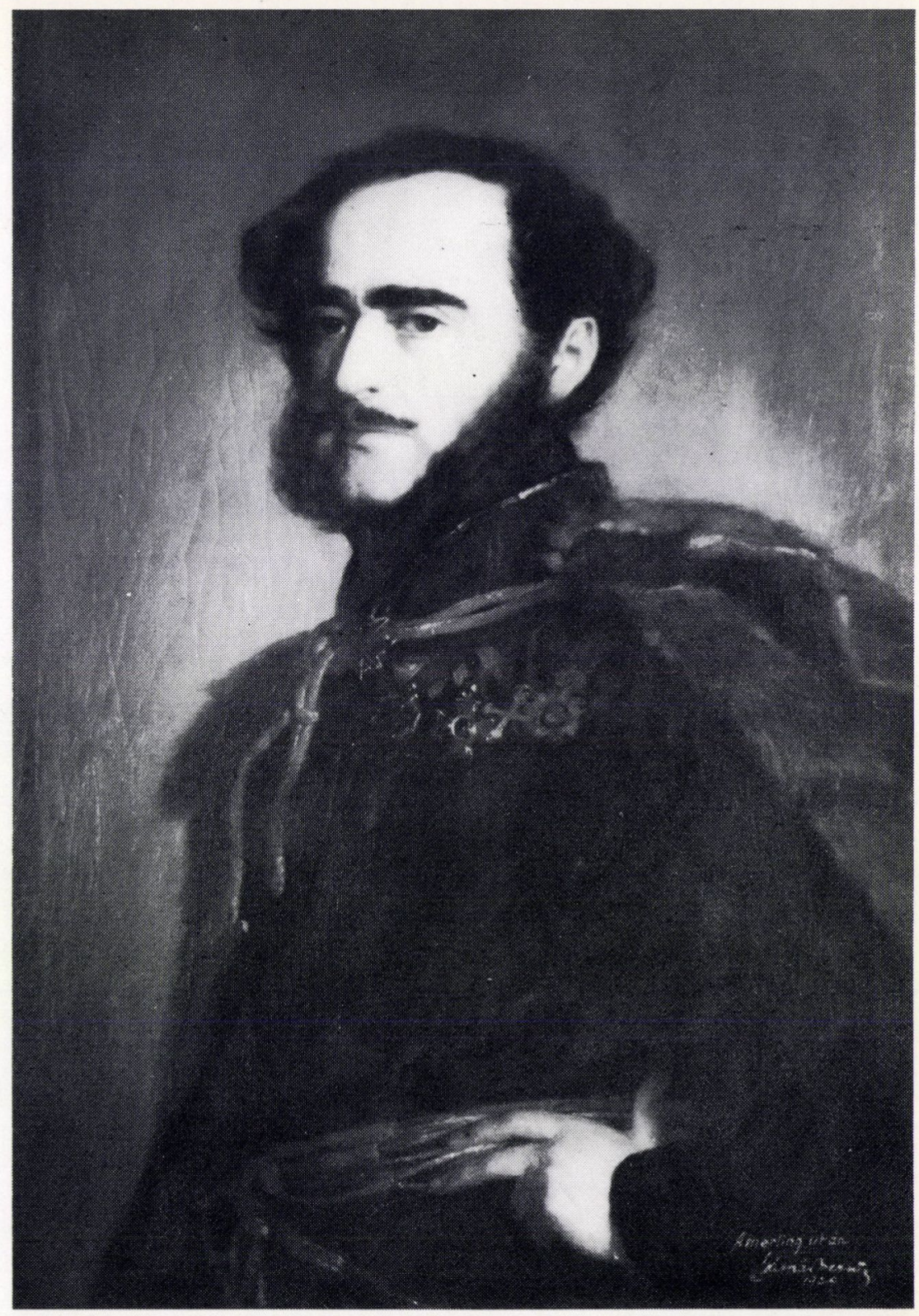

Count István Széchenyi 
Tolyoivatok

mullyate

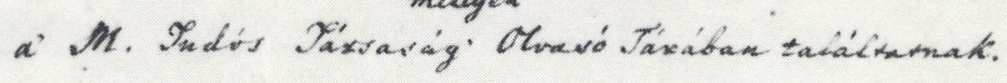

18.31.

1. The Edinburgh Reviear. 105. 10b. 10\% 108. -

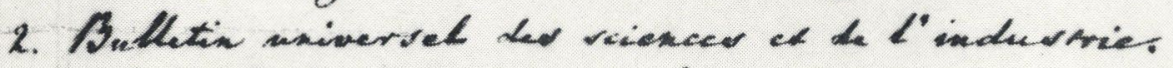

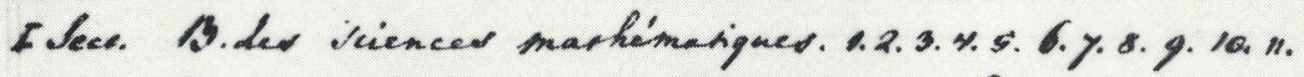
II- D. des reiences namalles. 1.2.3.4.5.6.7. 8.9.10.1.

* - Do des viences midicales. 1.2. 2.4.5.6. Y. 8.9.19.11.

11. - M. des siences agricoles. 1.2. 3.4.5.6.y. 8.9. 10.11.

W. - A. des sciences techarbogigues. 1.2 2.4.5.6.7.8.9.10.11.

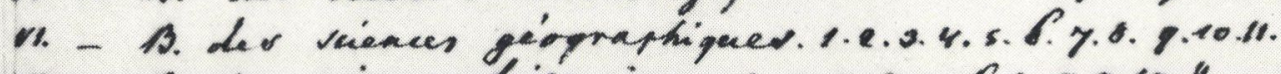

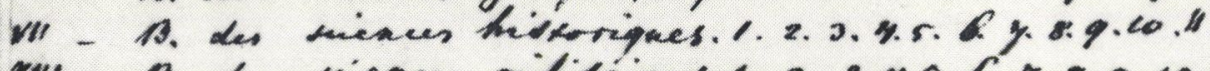

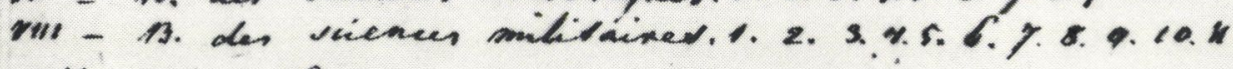

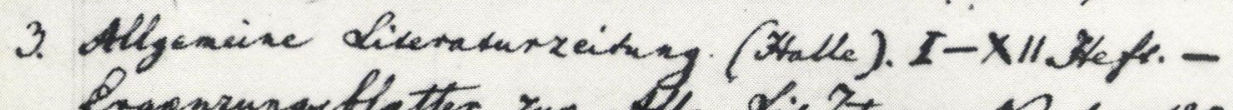

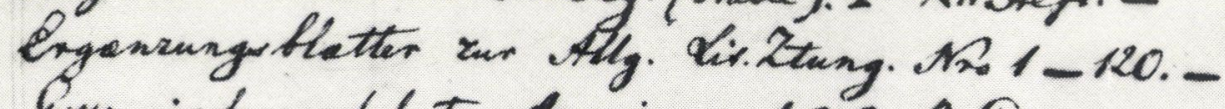

1. Sittingische gelehrte Ansuigen. 1.2.3 B.S. -

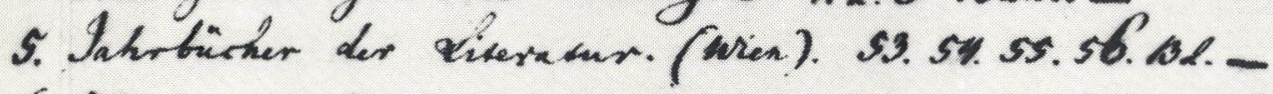

6. Hermes. $X X X V$ Bd. 1 is 2 Hegt.

$\overline{1832}$

1. The Edindurgh Review.

2. Antlecion nniversed des veciences.

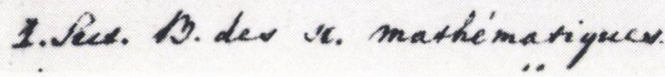

The catalogue of the first periodicals received by the Library 


\section{KÖNYTARI UTASITÁS.}

\section{Fejezet.}

A' m. academiai bünyvidr' rendellotesdnd.

1. 5.

A' magyar academia' 'Könyrtára fókép az intėzet tagjai használatára van ugyan szánrạ; mindazonáltal a' tudományos közönségnek is meg fog helybeni haszmálat végett nyittantni, mihelyt lajstromainak állapotja azt megengedendi.

\section{Fejezet.}

Az academiai bönyvtár' alkatndszei 's egymáshozi viszonyai.

\section{5.}

Az academiai könyvtár két fọ részre oszlik:

1) A' szorosan academiaira, melly 'egyes hazafiak' ajändékaibol, az országos törrény' rendeleténél fogva a' kormány' útján érkezett új nyomtatráryokból, 's az academia' vásárlásaiból áll; 's ehhez képest az academia' bélyegét viseli; 


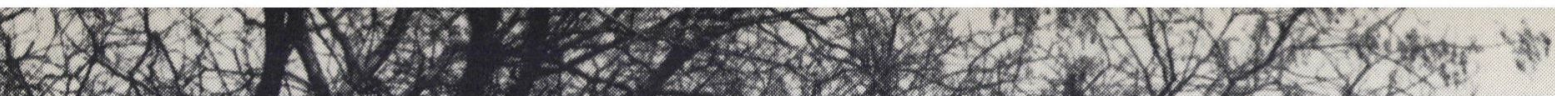

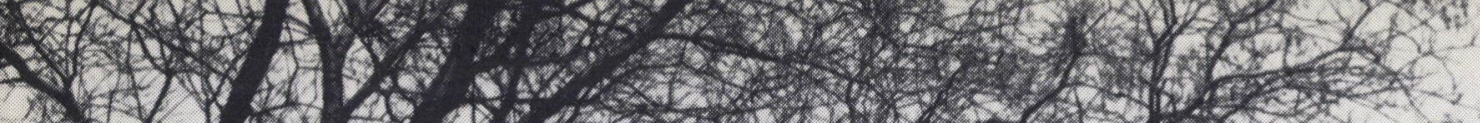
4.5.

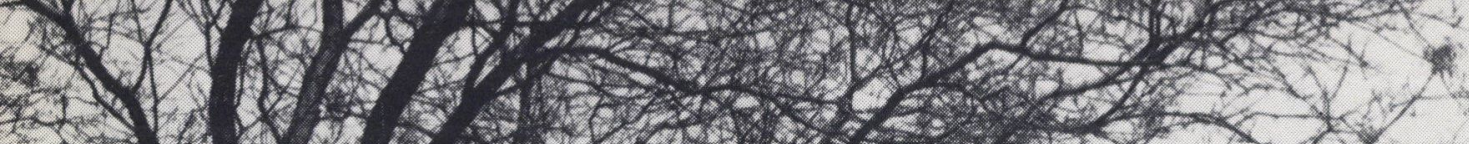
t.

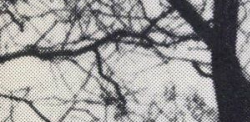

3

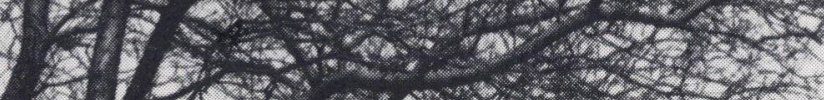

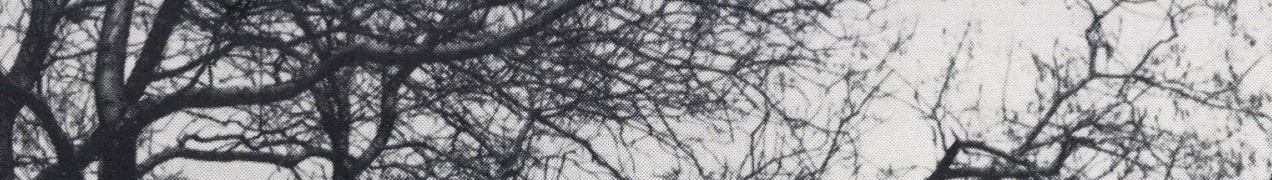

Sit

C.: 1.1
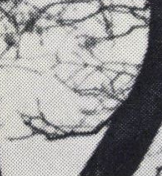

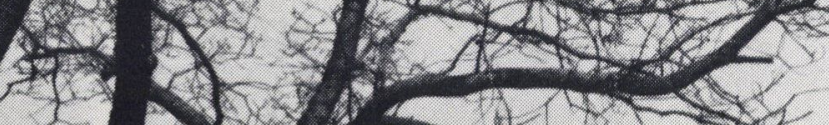
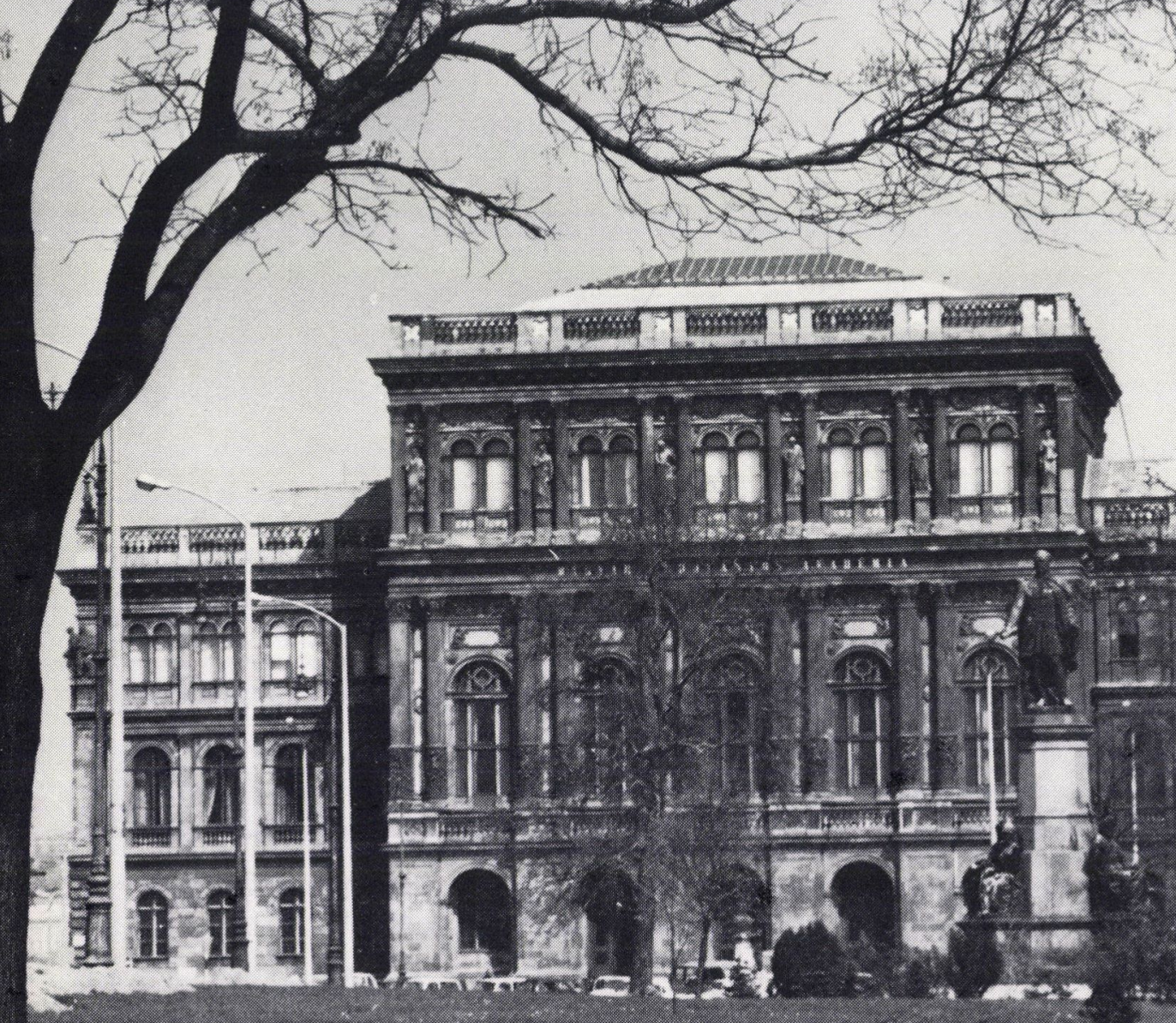

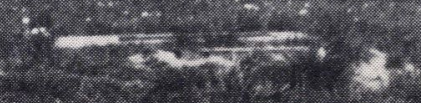




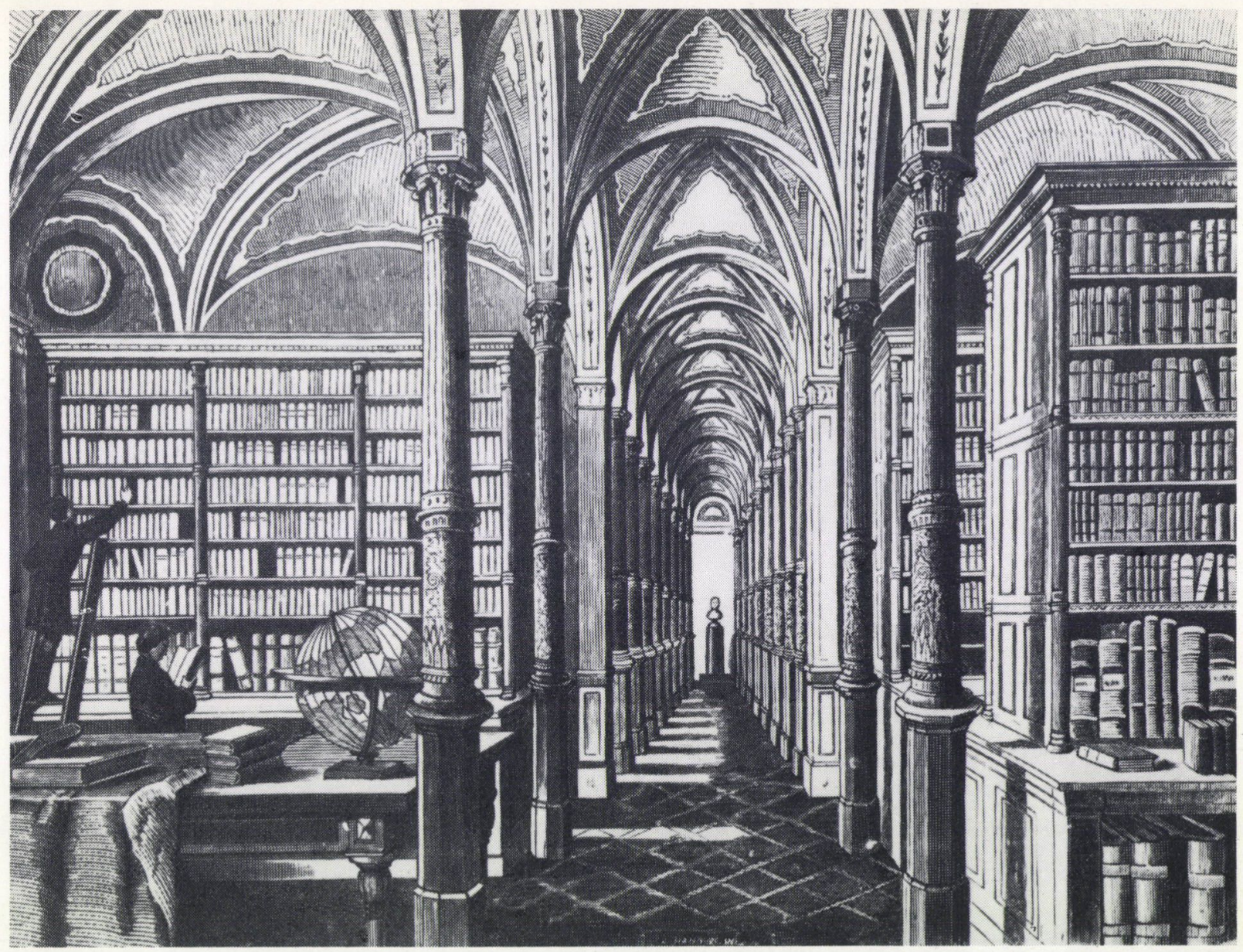

The old stack-room in the palace of the Academy. Engraving from 1865

4 The building of the Academy today 


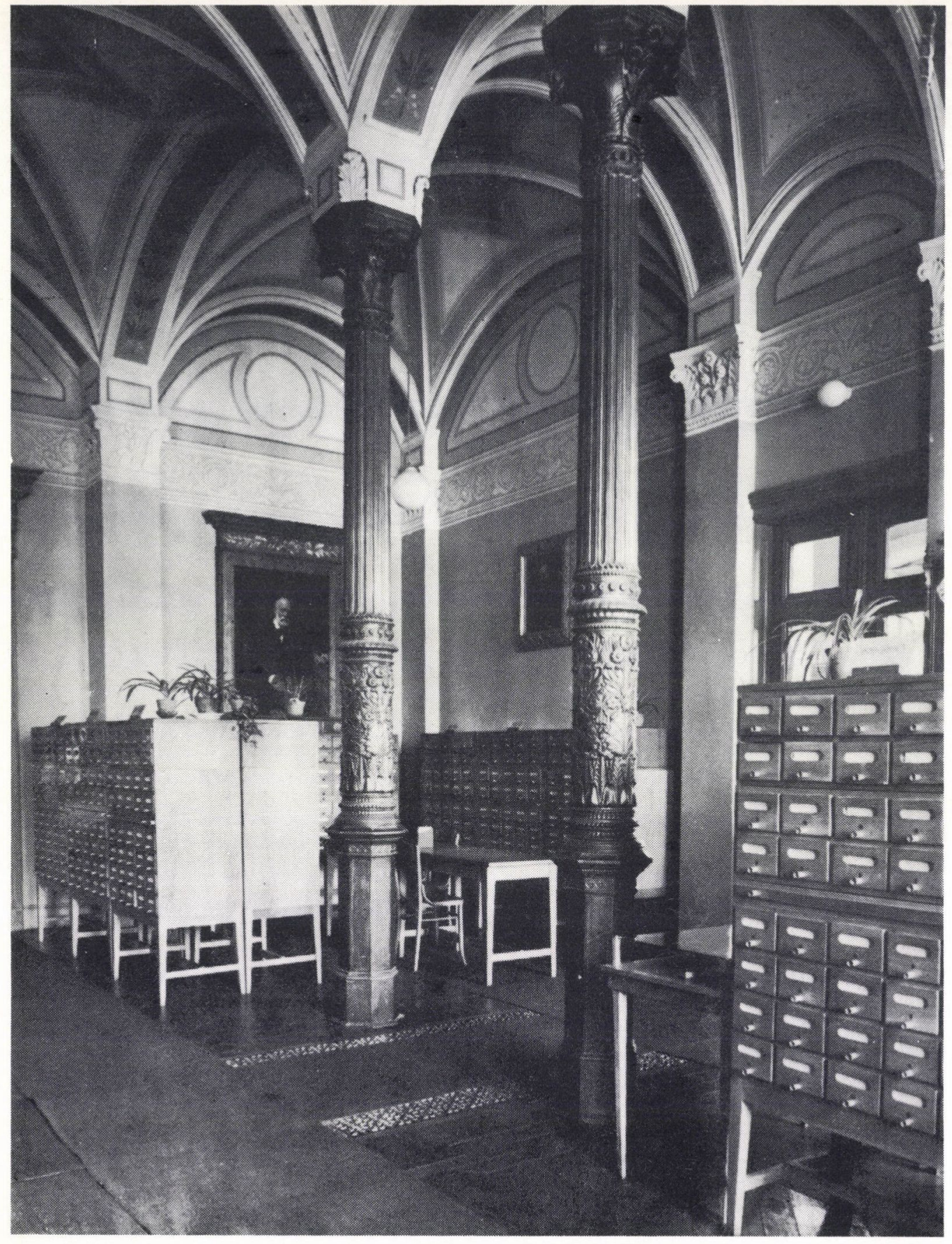

The catalogue-room 
gorers,

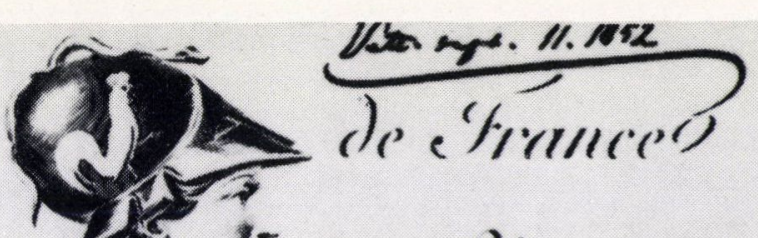

(S) molilue,

(x)ancimie

Hi den ef ciencens).

(i)

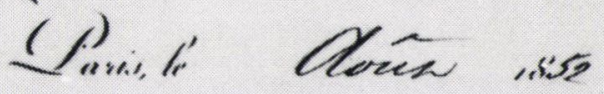

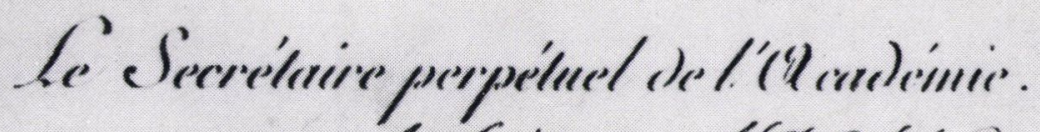

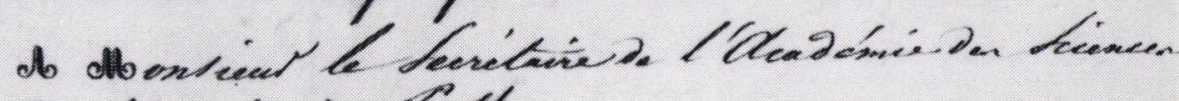

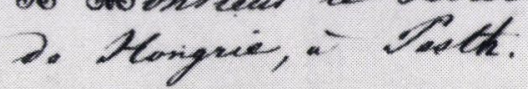

Memsinary,

L'bcadomic a repu lis ousragen que vous anez bien

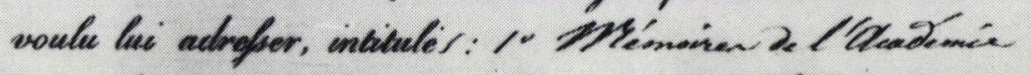

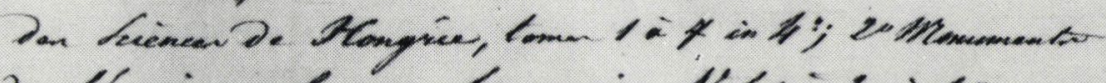

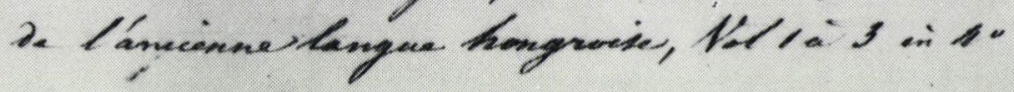

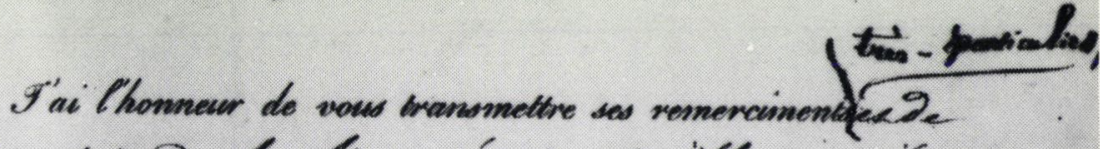

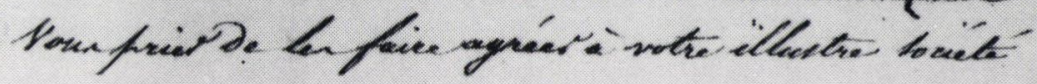

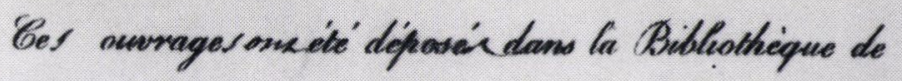
T.Tnatitur.

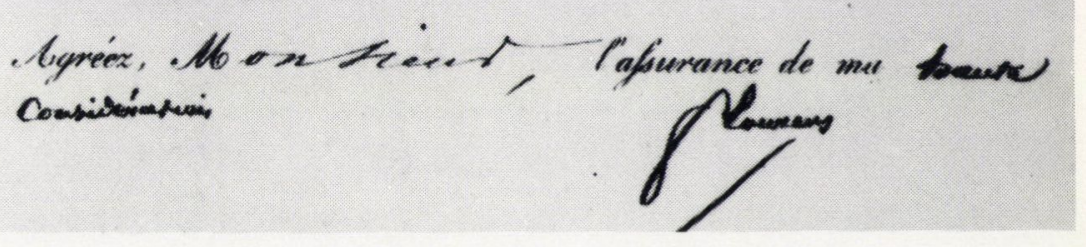

An acknowledgement card of the publications sent on exchange to the Institut de France 


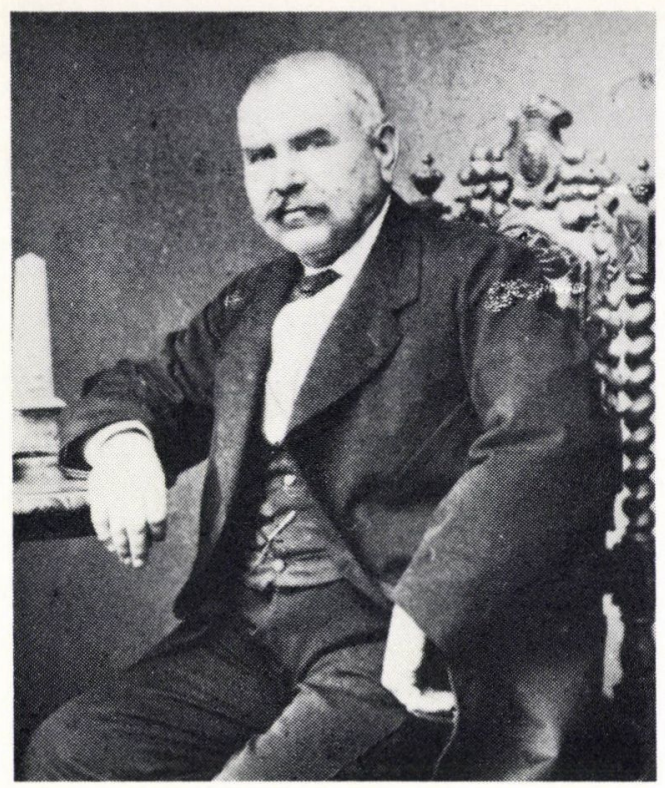

Ferenc Toldy (1805-1875)

secretary-general and in this capacity

he also acted as chief-librarian until 1851

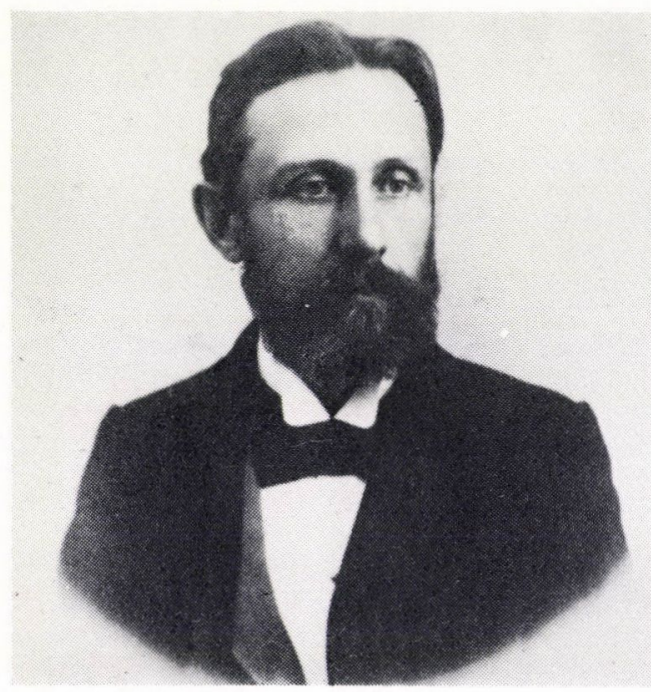

Ágost Heller (1843-1902)

chief-librarian: 1894-1902

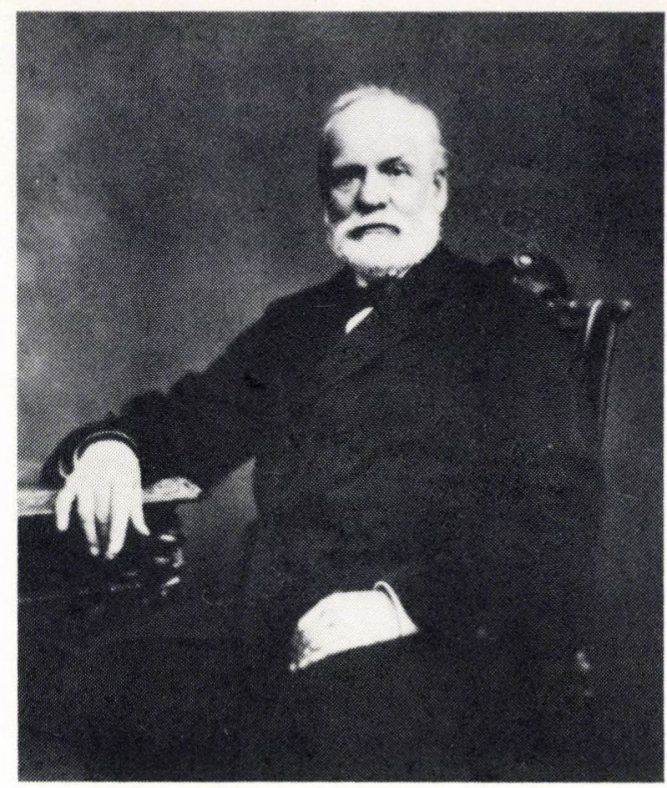

Pál Hunfalvy (1810-1891)

chief-librarian: 1851-1891

\section{CHIEF-LIBRARIANS OF THE ACADEMY}

Róbert Fröhlich (1844-1894)

chief-librarian: 1892-1894

(Photo is not available) 


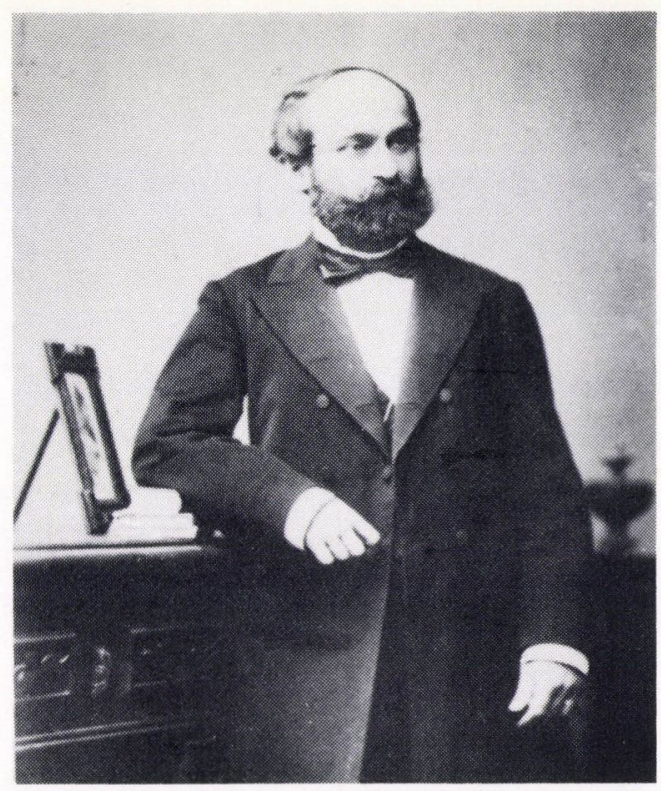

Kálmán Szily (1838-1924) chief-librarian: 1905-1924

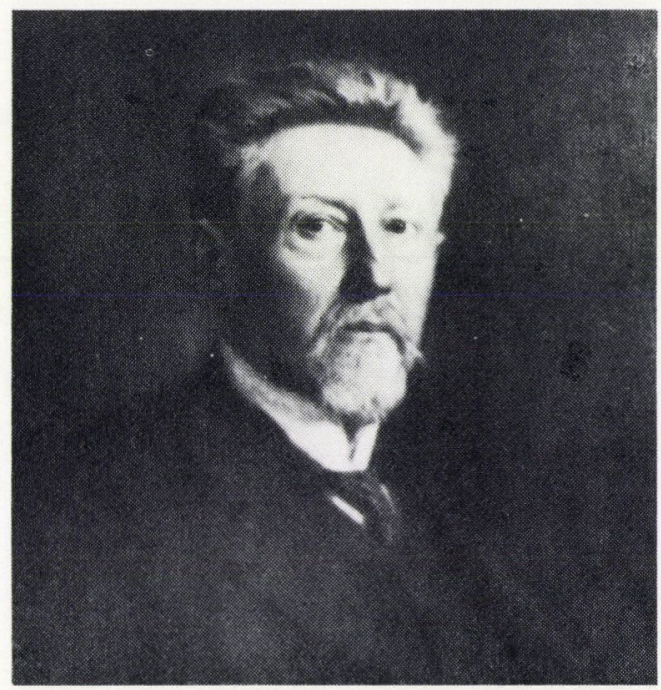

József Szinnyei (1857-1943) chief-librarian: 1928-1943

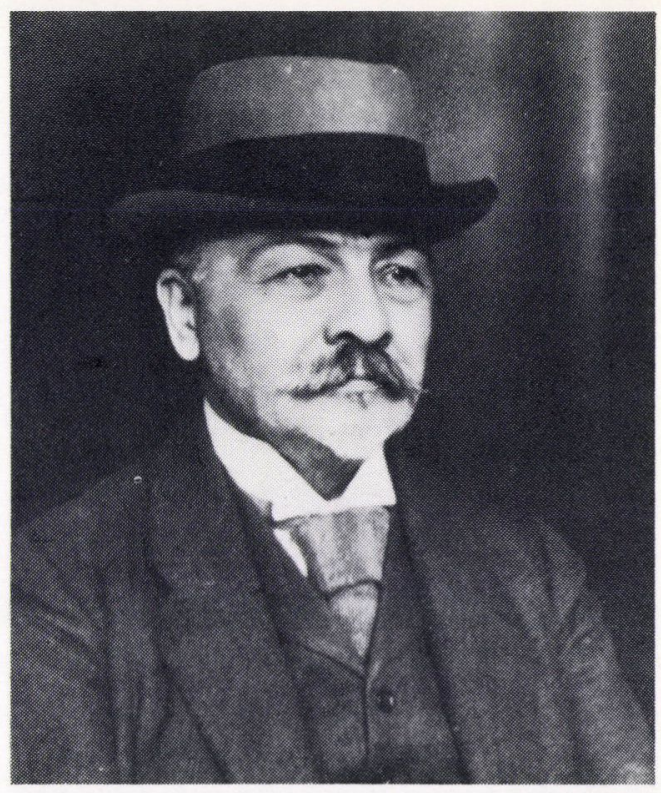

Zoltán Ferenczi (1857-1927) chief-librarian: 1925-1927

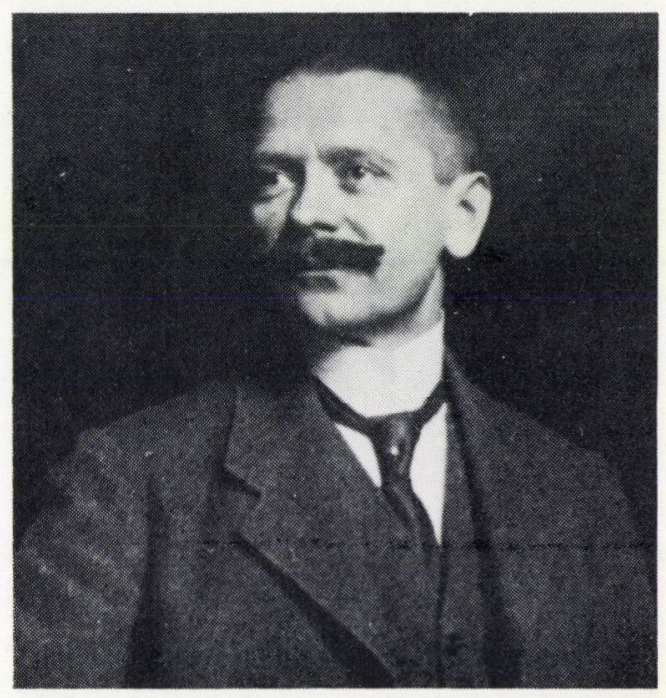

János Melich (1872-1963) chief-librarian: 1943-1948 
4.3

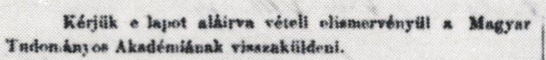

A konyvek jegyzelke

melyek escomaghan kzaim alatt

penti kbinyvkereskedik altal kuldettek.

A

1. A Ningyar Tadomanyo

Akntémia réaziral.
None prions de renvoyer cette feaille nignie pour servit

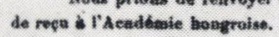

Linte des livres

envoyés dane

putquet aous lo $\mathrm{No}$

lar

Hibutire \& Pant

¿ I' Academie Imperiale des Sciences.

Peilessbaurg.

1. De lu part de TAcadémie hougroise.

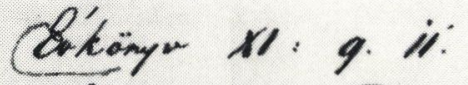

Wyalumdum. Nixlem. VI: 2.3.

Atrohaed. Kixlem. VII: 2 .

Clatirt is romkely Rixlem IV: $2 . V: 1$.

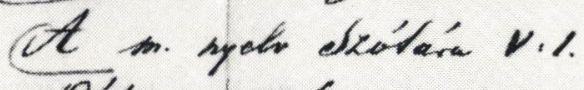

ETositu" 186s: $1-18$ ar.

Magyan tiot tán roll.

Monumanta. Dislom. $x$

Chonmonenta. Soxph VIII. NIX. XXIII:12.

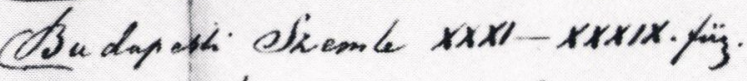

Mrup : Budapest töbinete

A list of publications sent on exchange to the Academy of St. Petersburg

A letter of Wilhelm Radloff to József Budenz 


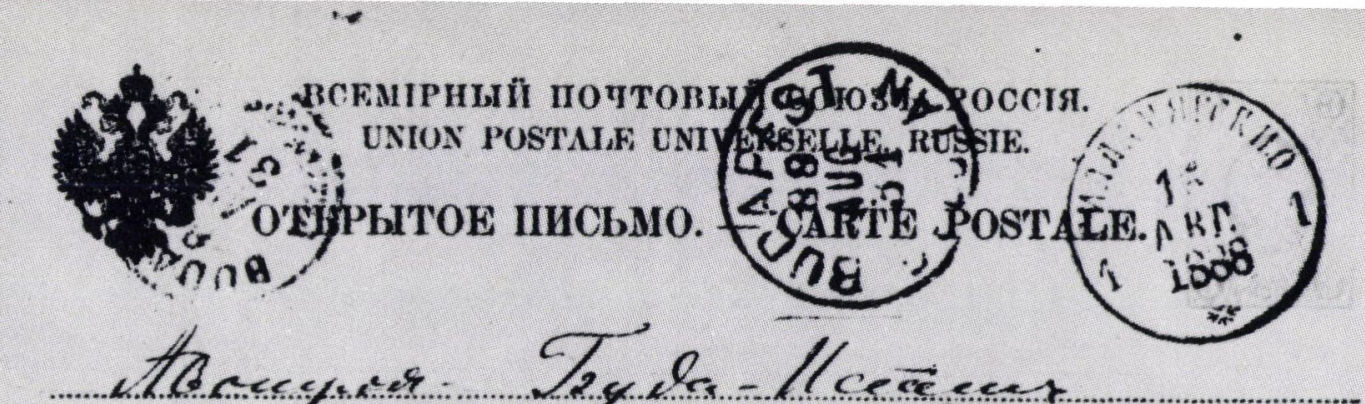

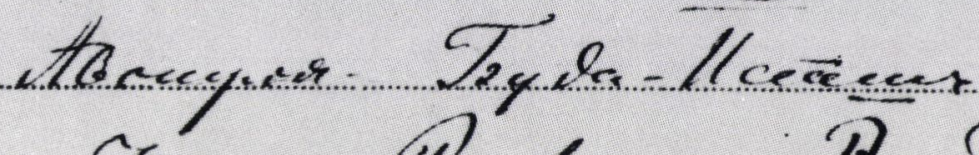

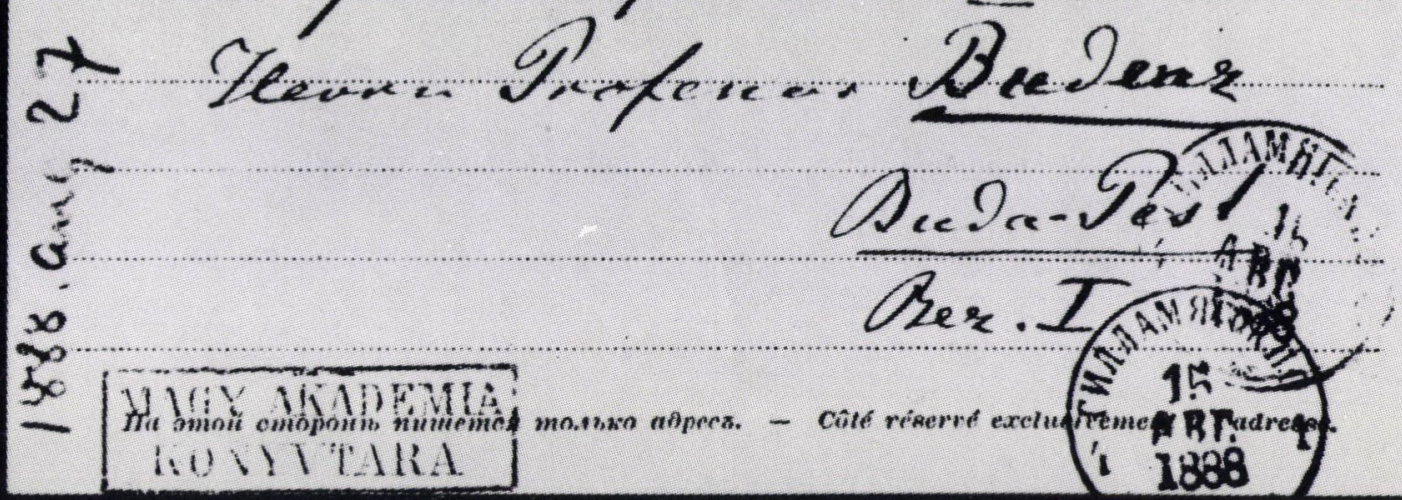

Ms $5449 / 202$

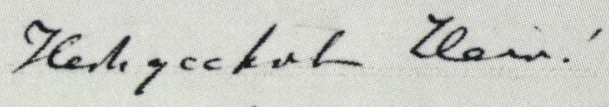

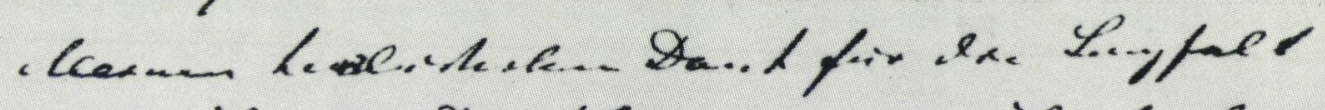

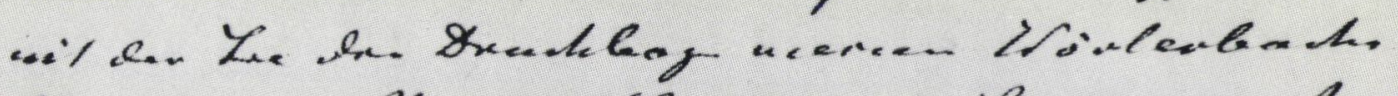

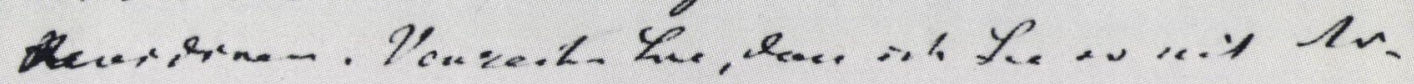

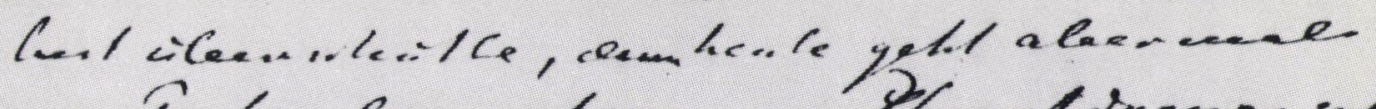

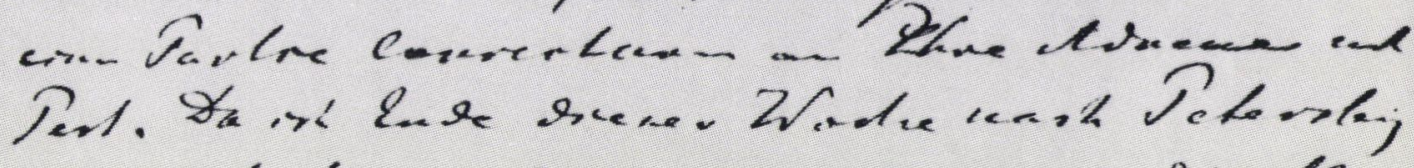

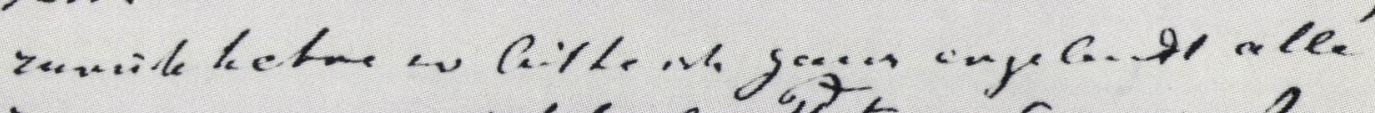

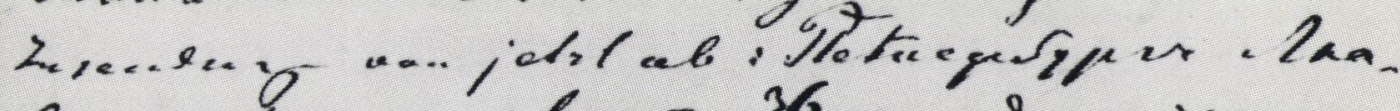

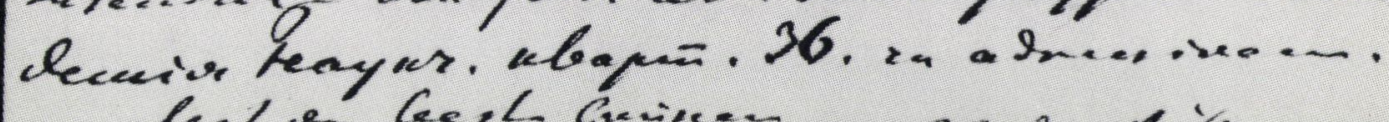

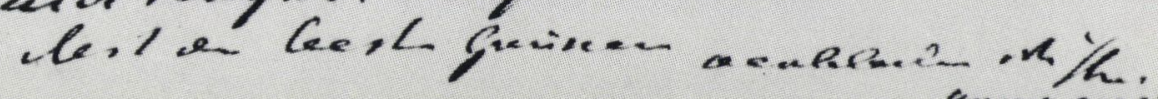


it

7.

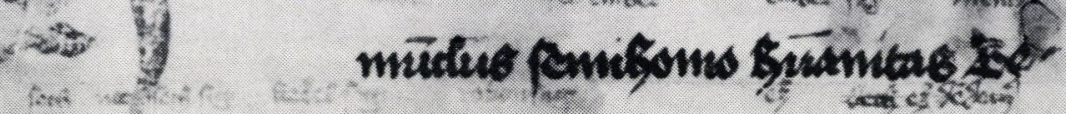

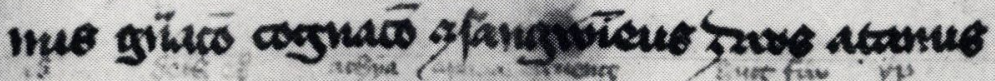

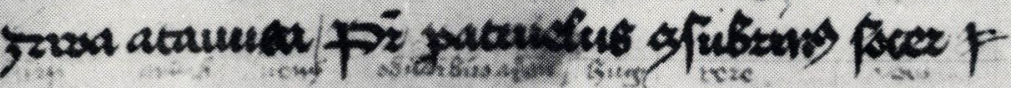

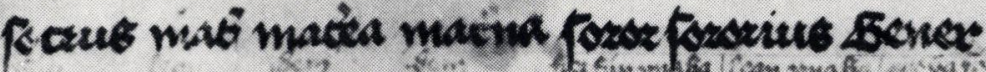

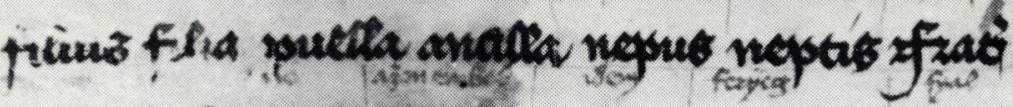

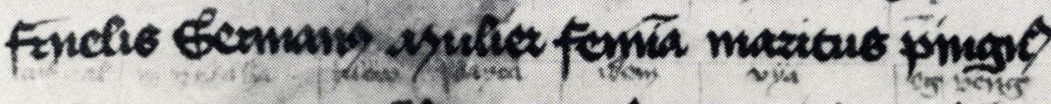

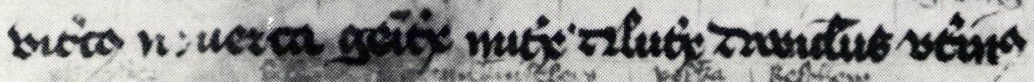

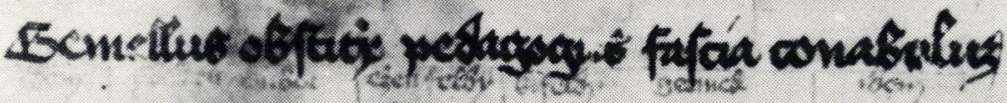

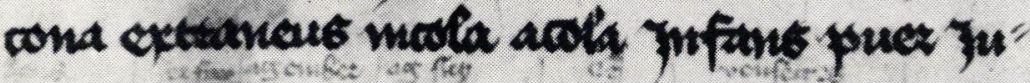

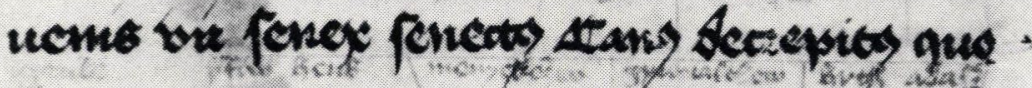

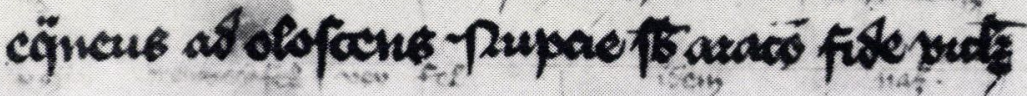

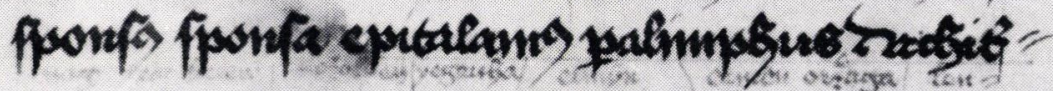

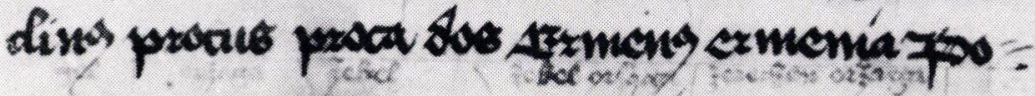

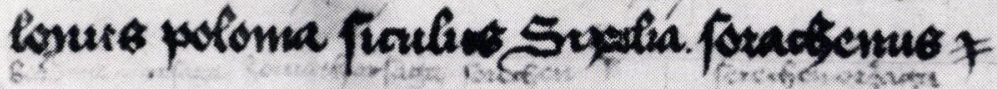

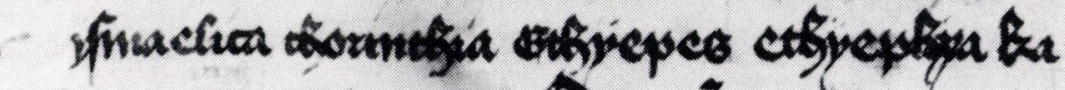

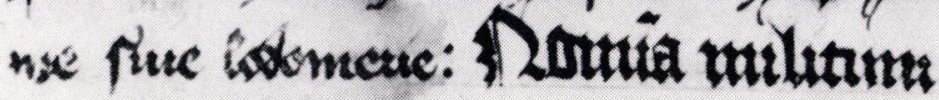




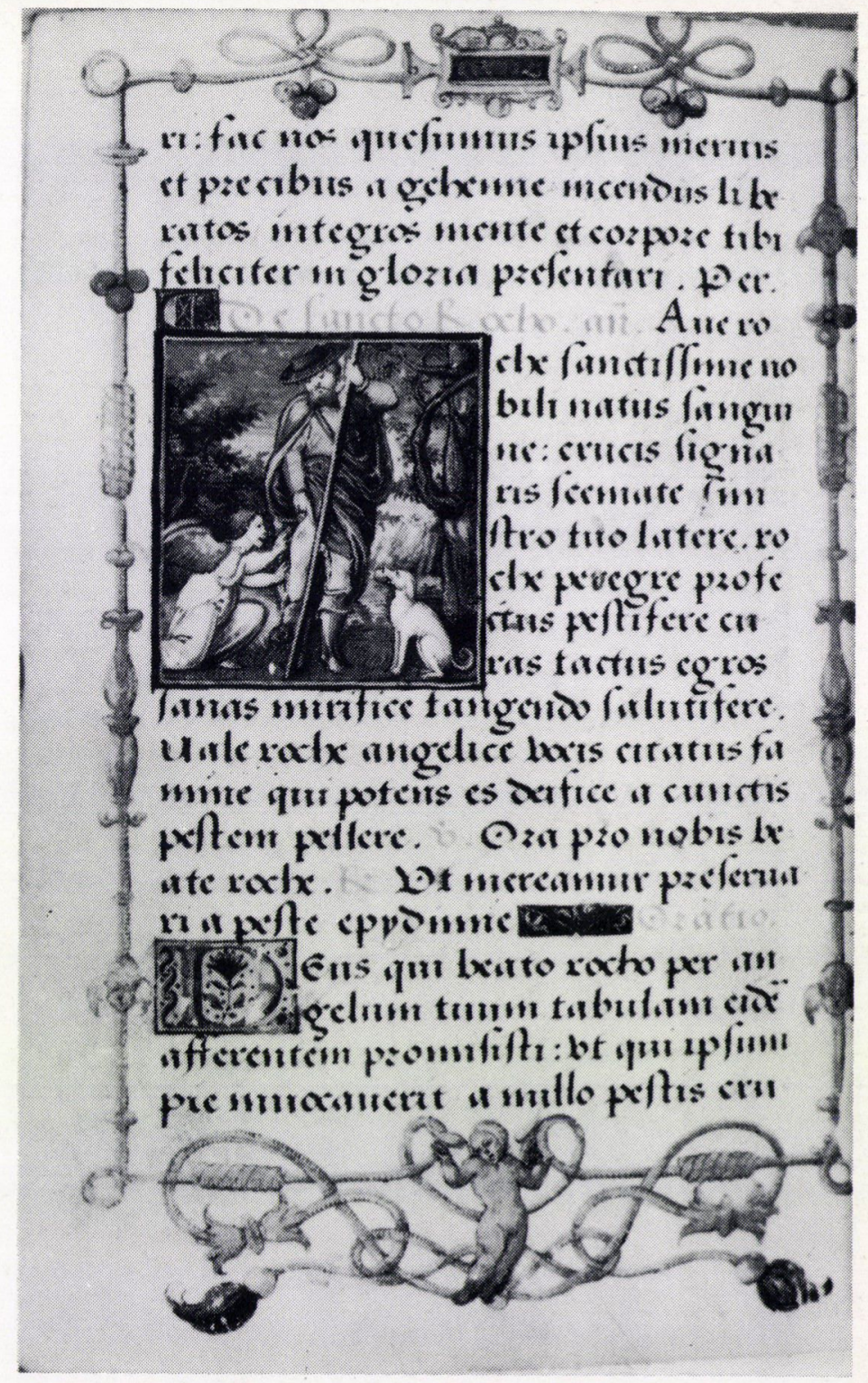

Horae Beatae Mariae Virginis. A codex of French origin from 1540

The vocabulary of Beszterce, a linguistic record, approx. 1380-1410 


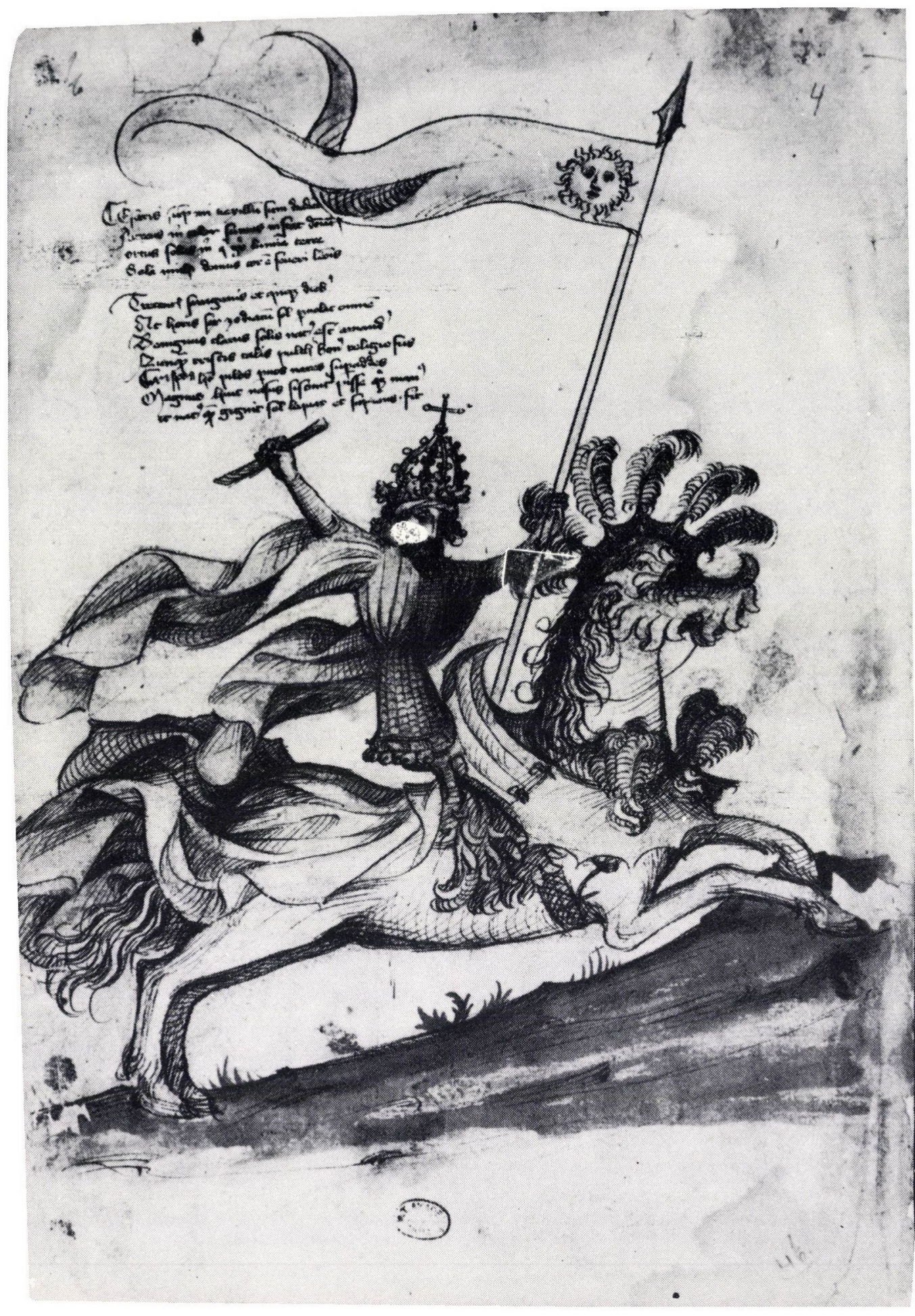




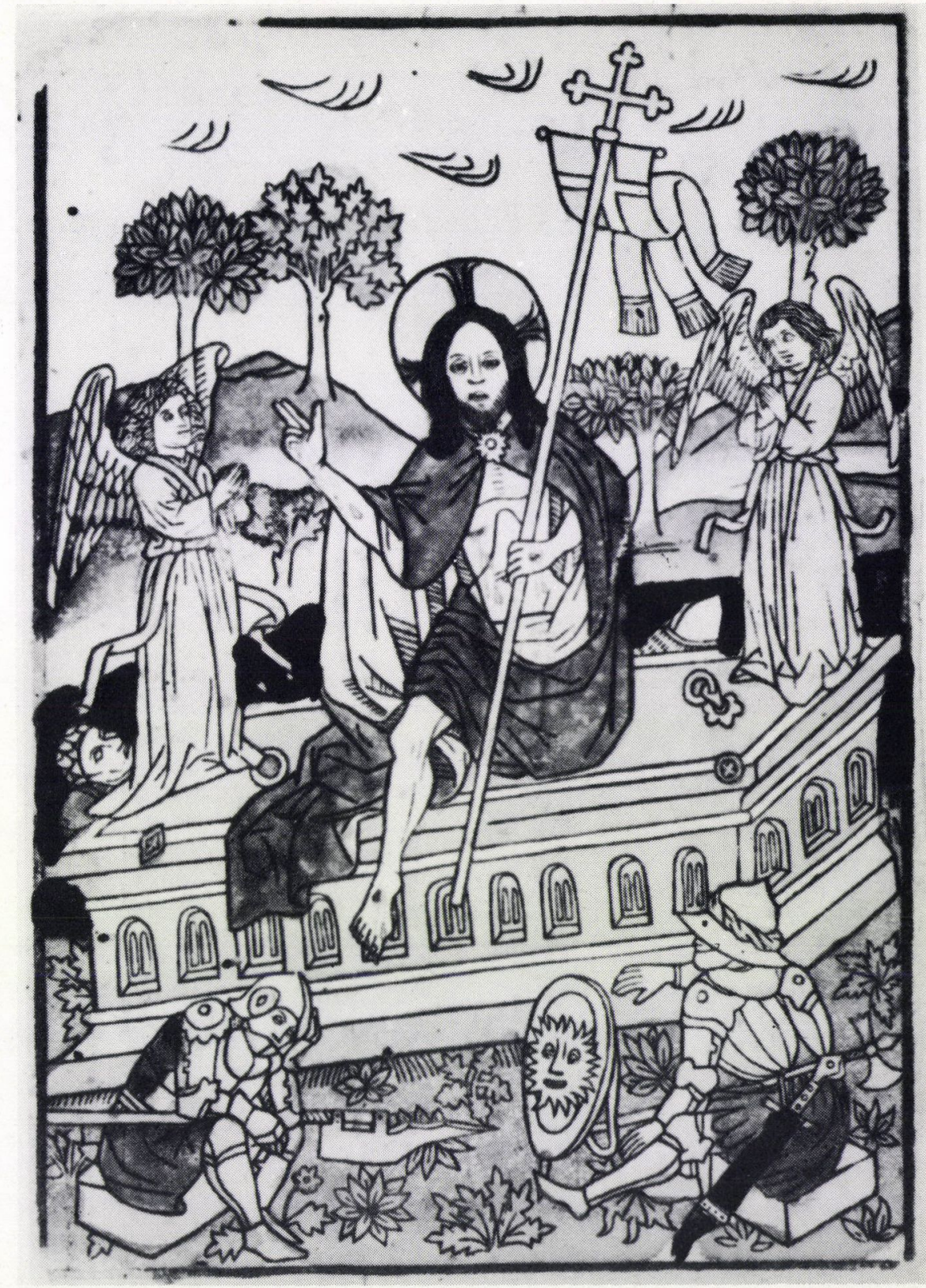

Coloured block print from about 1430

4 Kyeser, Conrad:Bellifortis. An illuminated fragment of a codex from the beginning of the 15 th century 


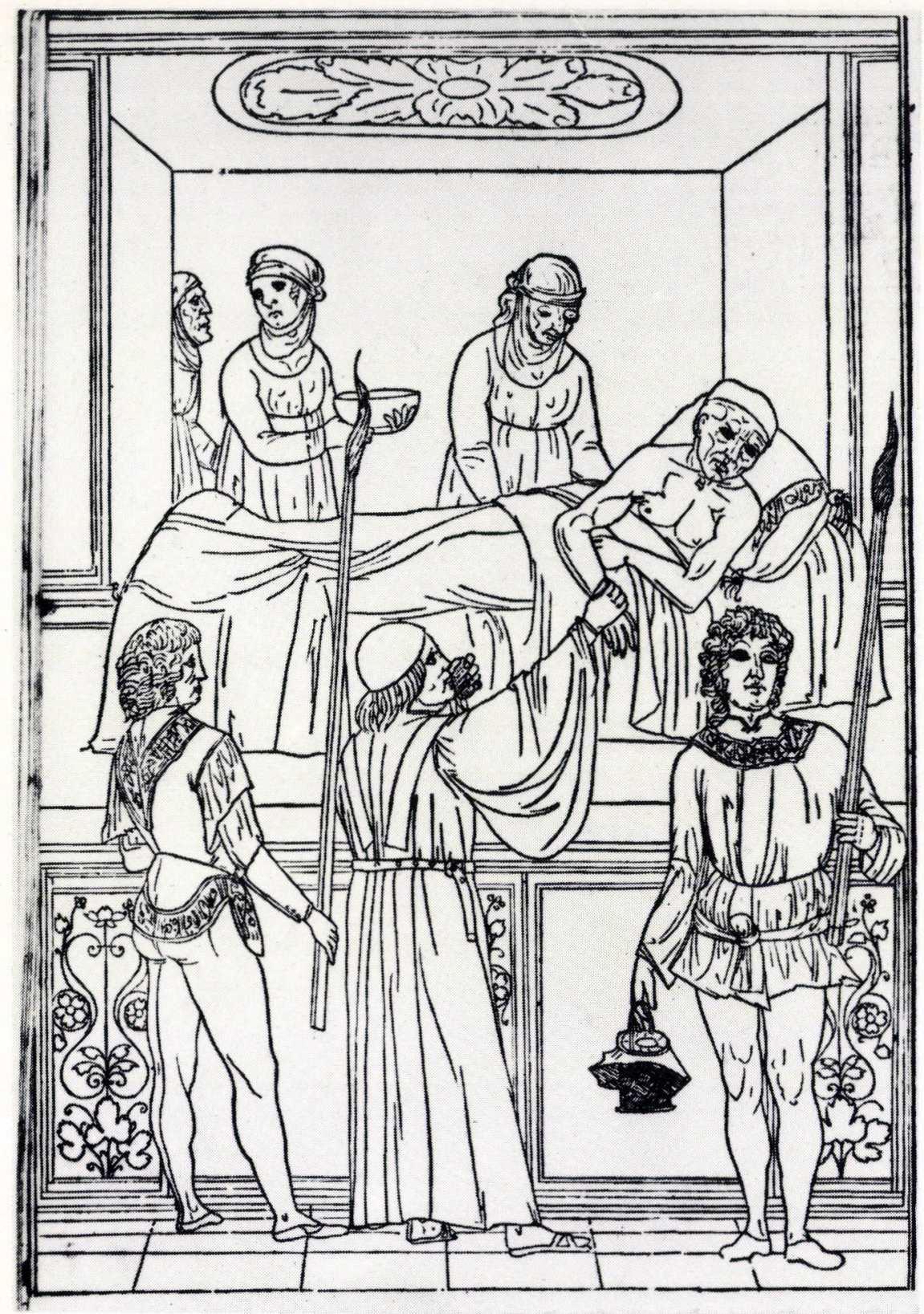

Ketham, Iohannes de: Fasciculus medicinae. Venice An incunabulum from 1500 


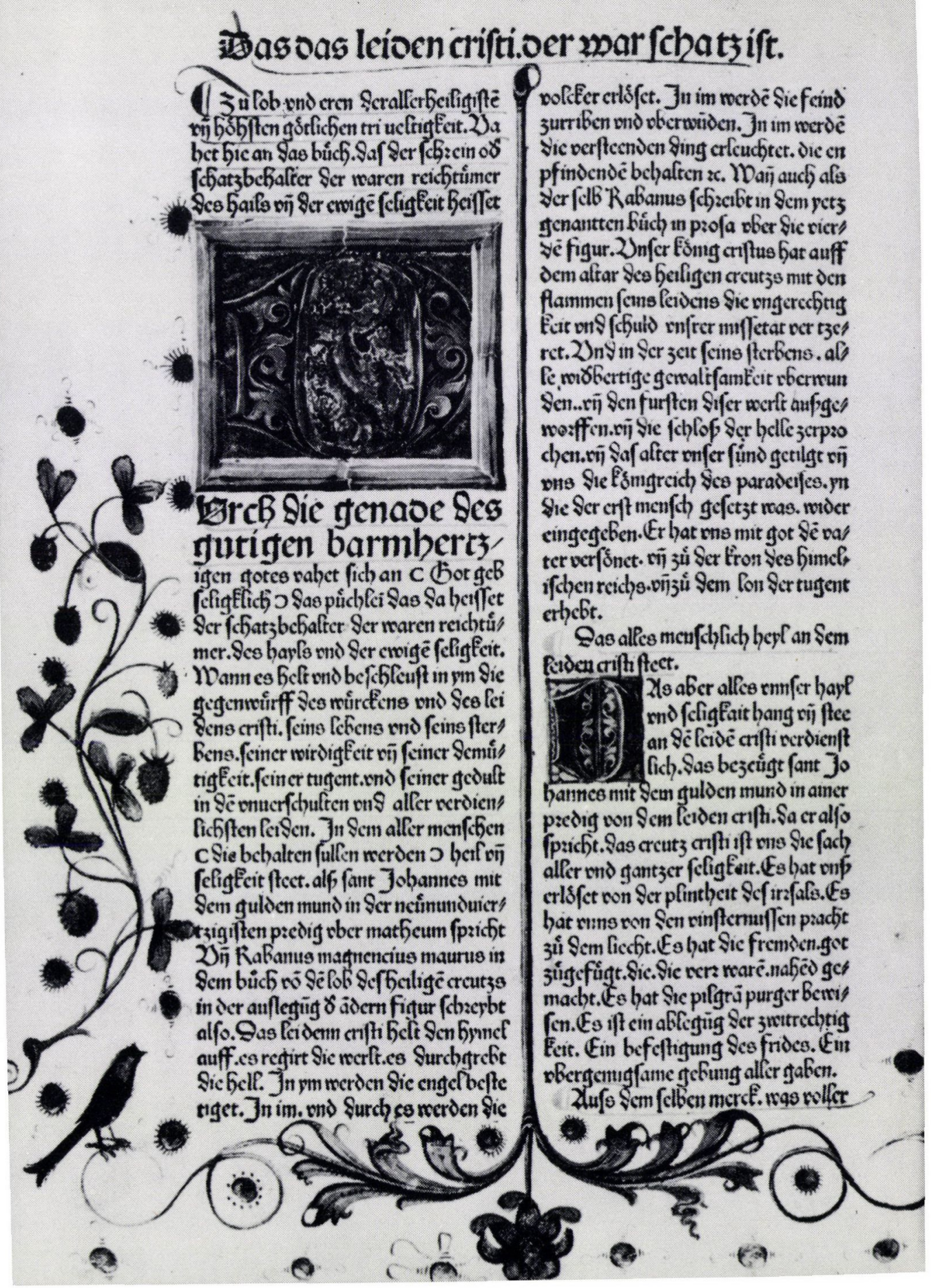




\section{EPISTOLÆ \\ PAVLI LINGVA HVN GARICA DONATAE.}

\section{AZ ZENTH PAAL leueley magyar nyeiuen.}

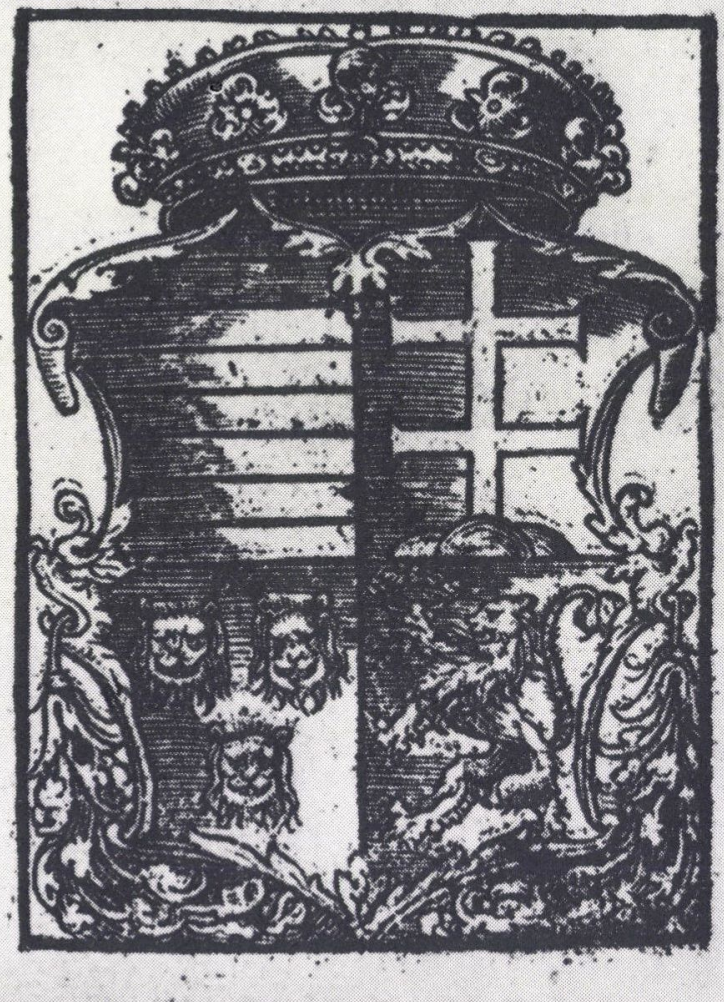

The epistles of St. Paul

Cracow, 1533. The first book printed entirely in Hungarian 


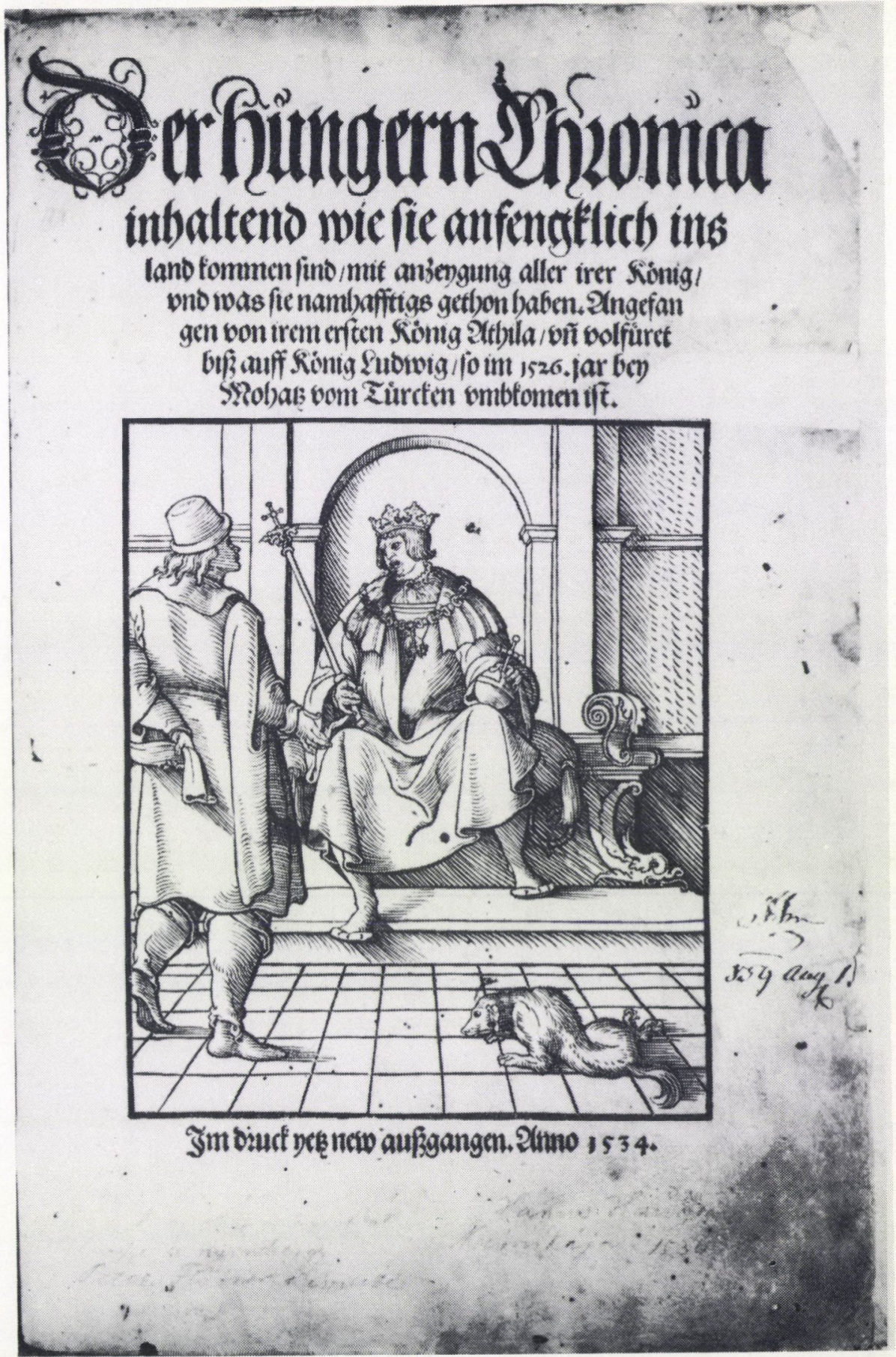

Haǔg, Hans: Der Hungern Chronica. A so-called 'antiqua' from 1534 


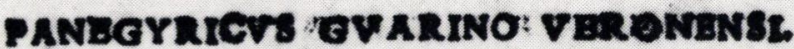

Quantos cu laum foufifti folns in ctbern,

Inde duplex Venetze procilfic goria ganes

Barbarusex pleatro calder Leonandis cburnex

Inde Iouis genitus de ftirpe Geongius aluis

Cretrafimilinguir quem lacte fob Ida

Digntpolenutrix:26apes non rauca feants

Cymbalapurpureismelcongeffench hellis:

Hinc ueterum nullícedens Caftellus auorum

Martius: 2 Latiznunciam lux altrera linguse

Martius undifono quem Namia monte creauit:

Martius acternum Iani fub peatore nomen.

Hinc Aganippero Tobias fonte rigatus.

Sed Titus hac ipfalonge perfufiorunda:

Seuliuso pugnasigythara feu cantet amores:

Intexens Paphiaclaurum Pamafida Mrtos:

Chrus \& hiltoria Satiustnec dignus iniquis

Inm Perrus podagrist \& acerbo Lamolalceto.

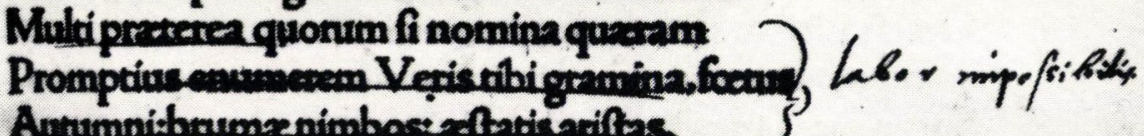

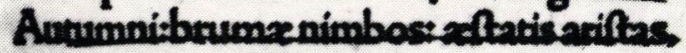

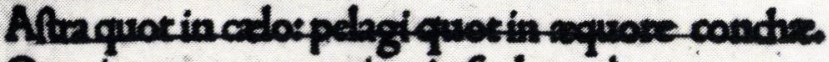

Quos intransermeuenientia foda medount.

Primus ego Eridani parrium de gurgitead 14 fumm

Mnemolidas Phocbo ducam cominnue forcress

Primus ego Niferderam ol bi Drane cong ab bos

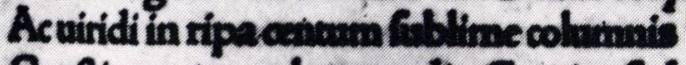

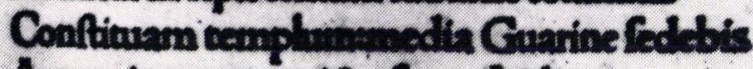

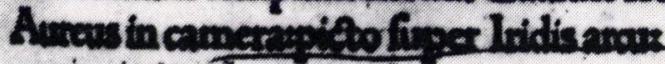
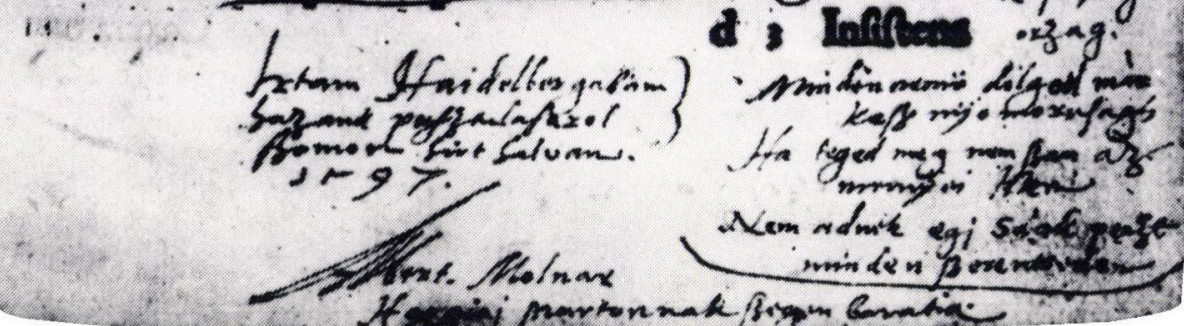

1 Inima ozzag. Doces o moipoting Cemedic conativer

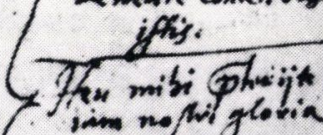
mibi phisint. 


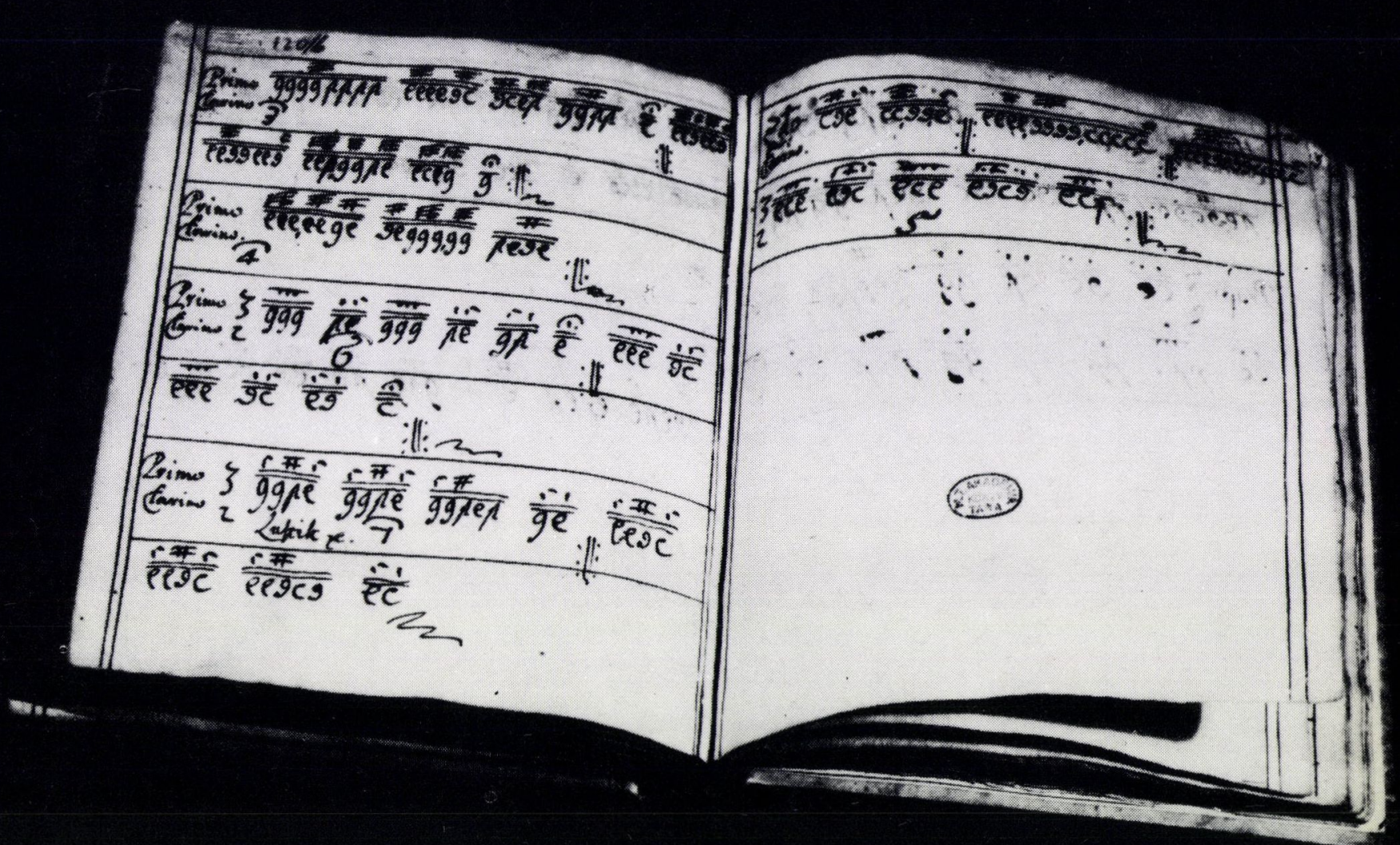

Codex Vietorisz. A musical collection from about 1670

4 A poem and a gloss of Albert Szenczi Molnár from 1597 in a collection of poems by Janus Pannonius 


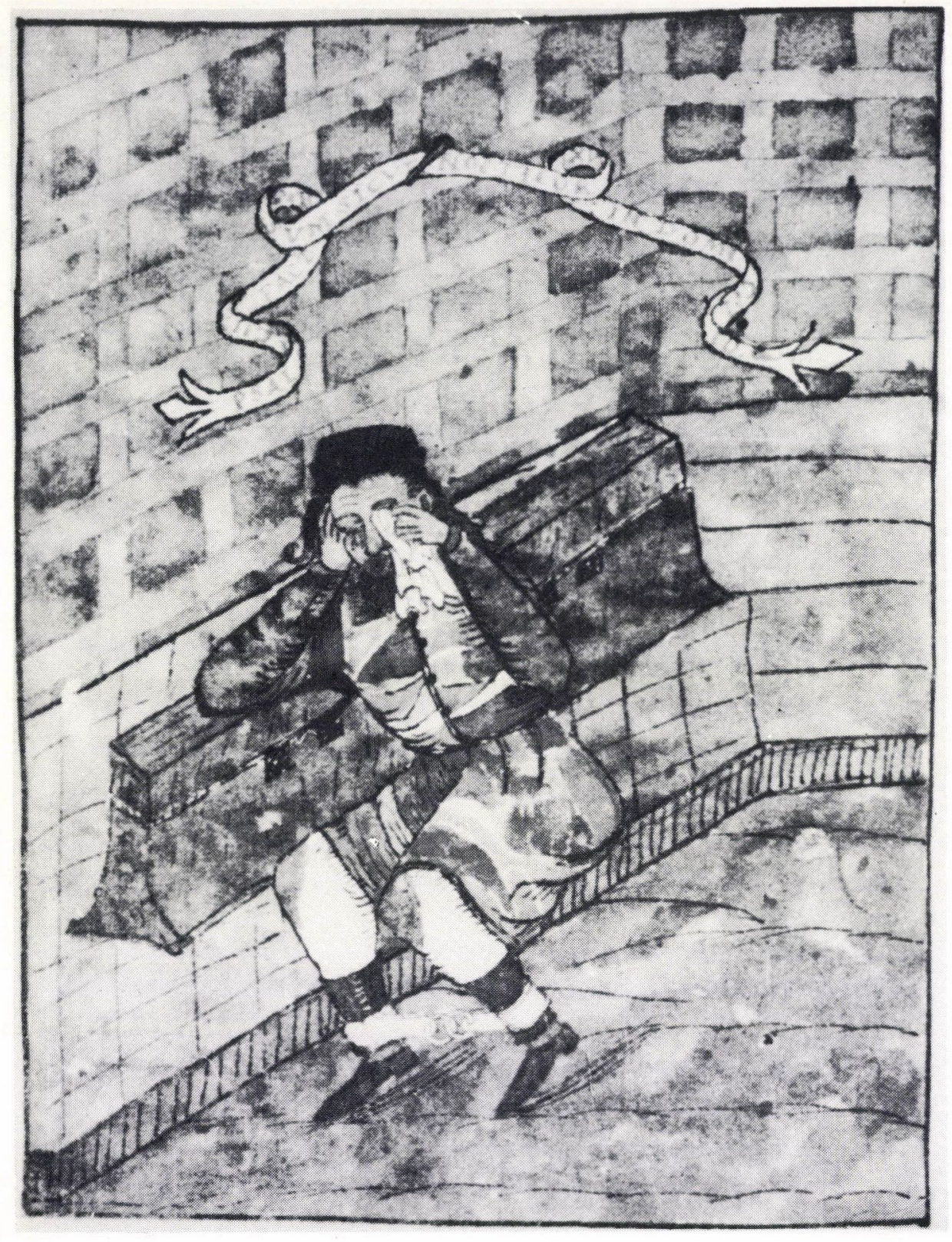

A hymnal by Ferenc Wathay from 1604 


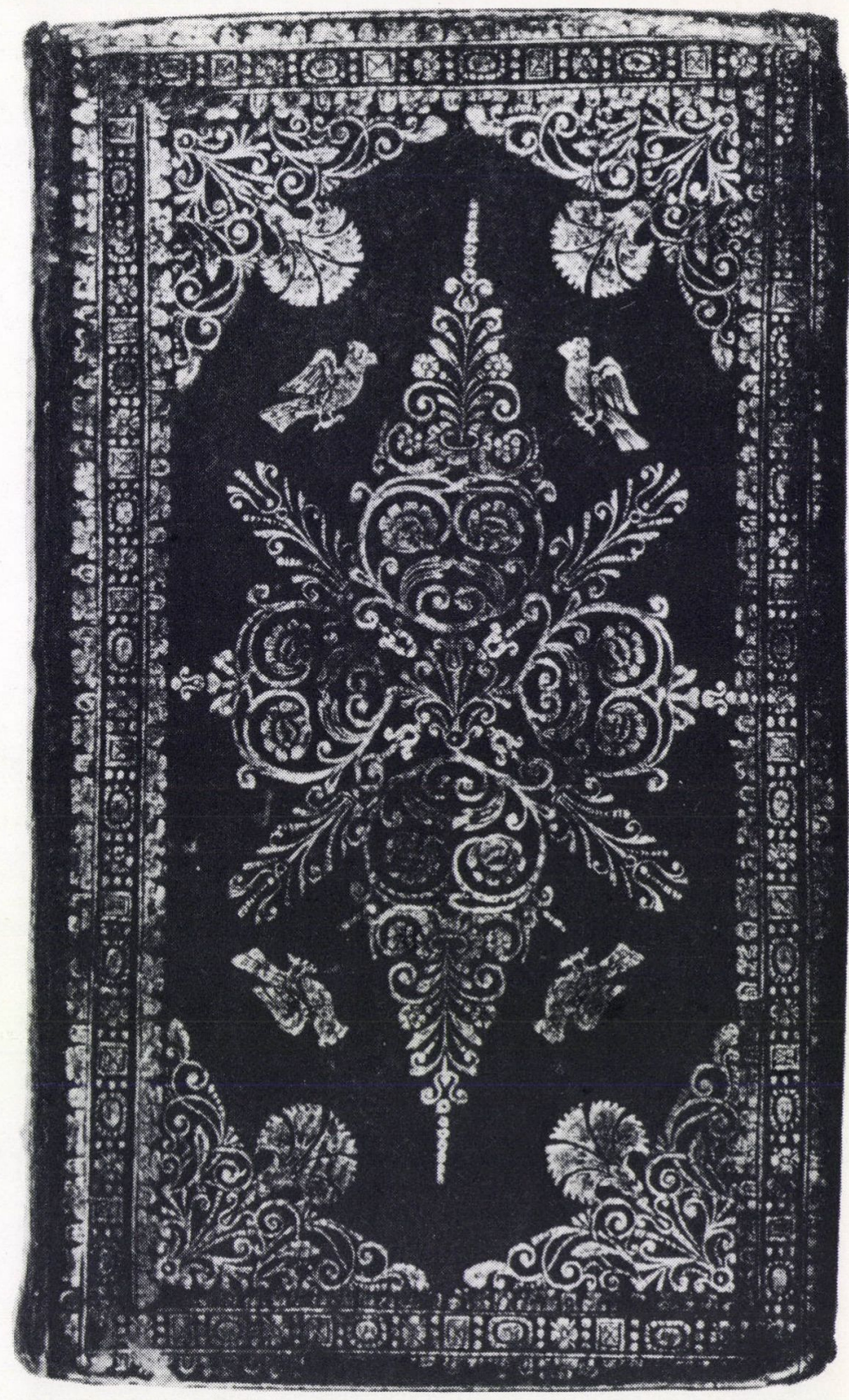

A binding of Kolozsvar from the 17th century 


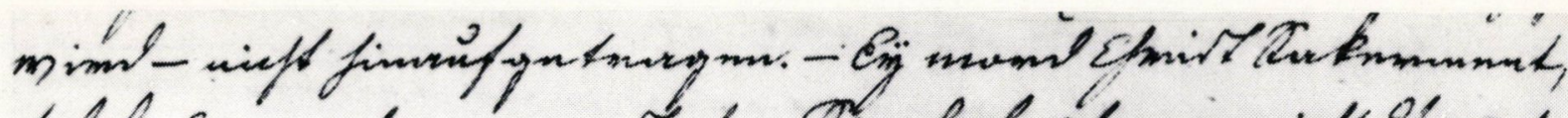

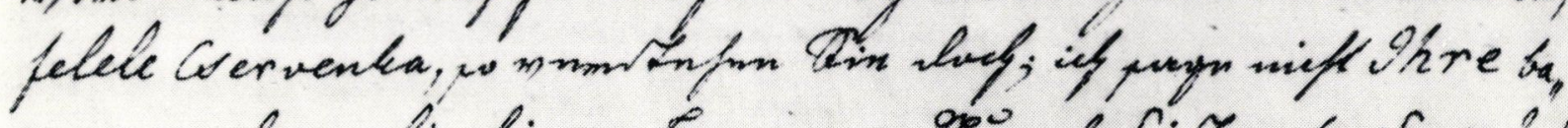

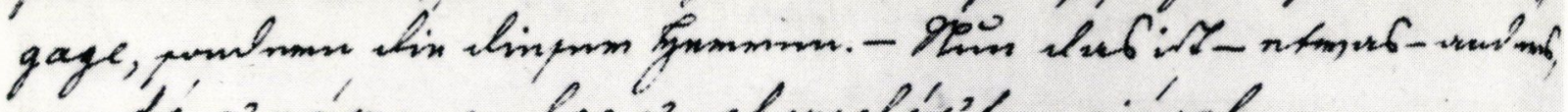
monda' a'réoreg ember a'nehequelés' hangiával.

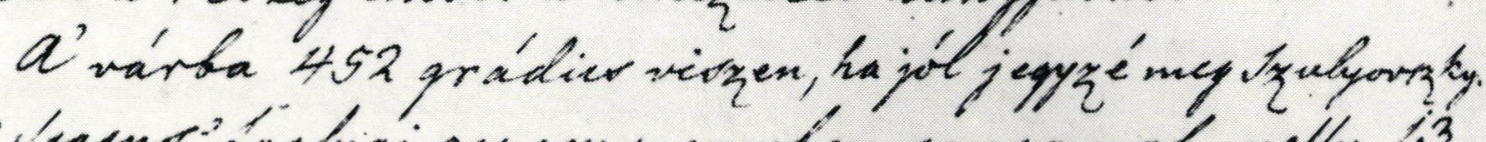

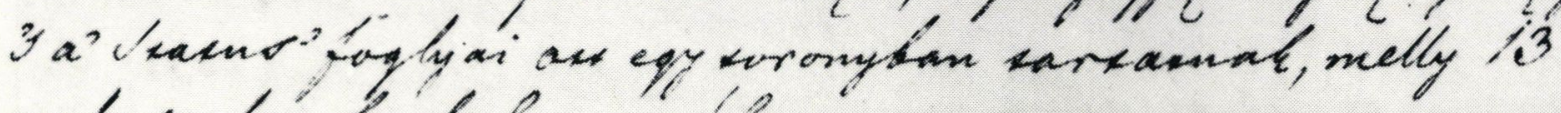
rekepclé foglal majábar:
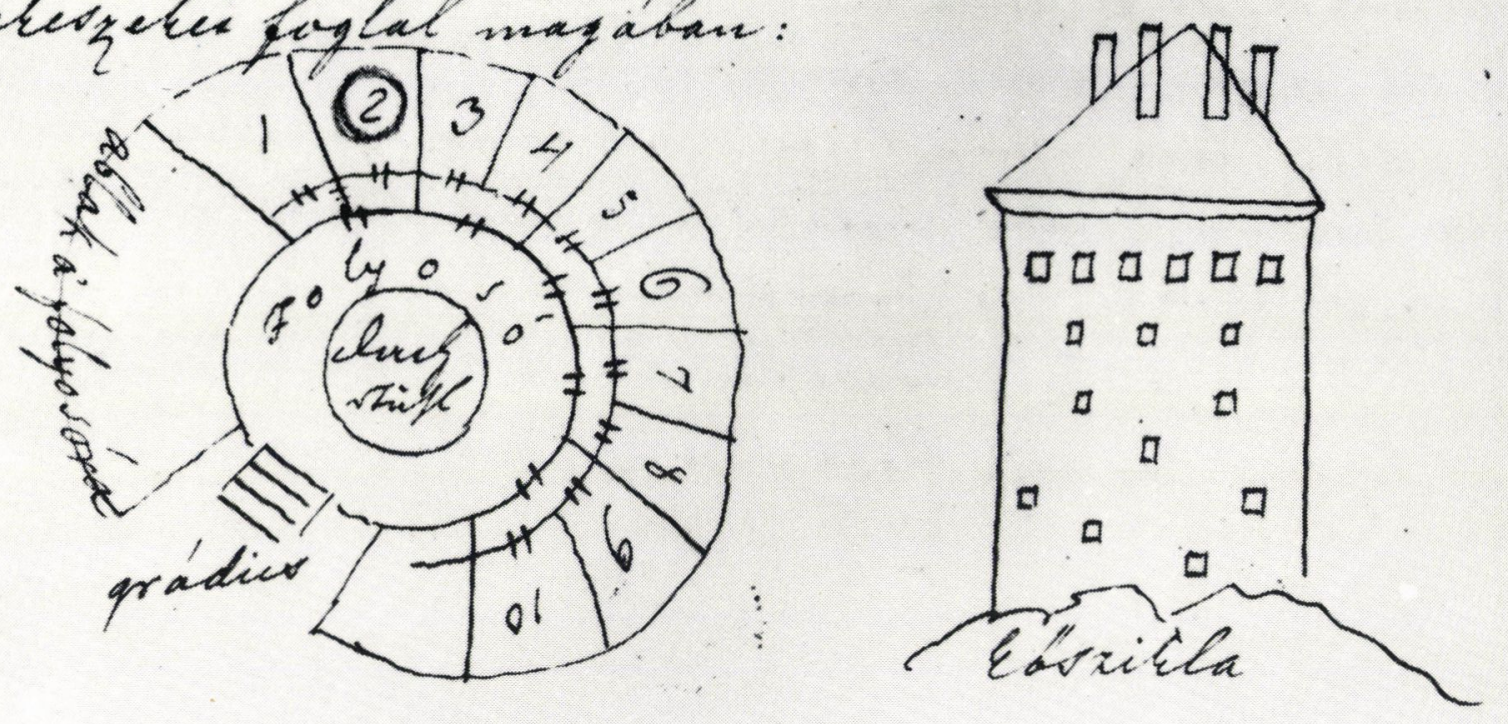

Kazinczy Ferenc: Fogságom naplója (The diary of my imprisonment) 
Manuscript of a poem by Johann Wolfgang Goethe, and his silhouette

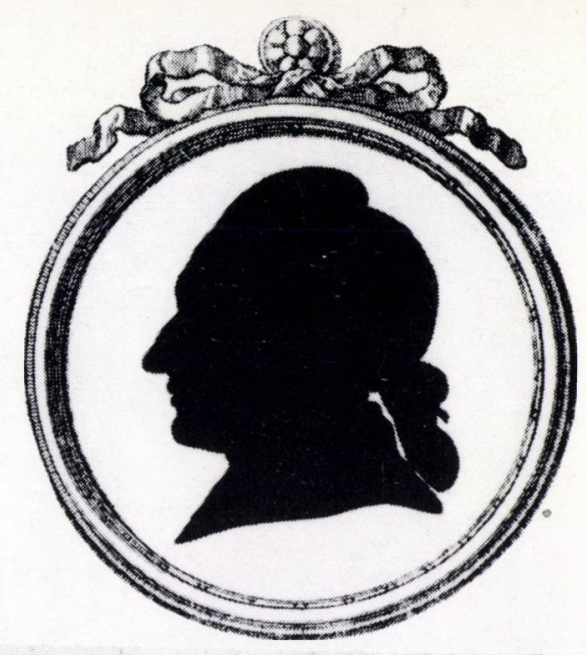

Whi aben yaen wit Hane var Eq? Mit Phidier nue mefter?

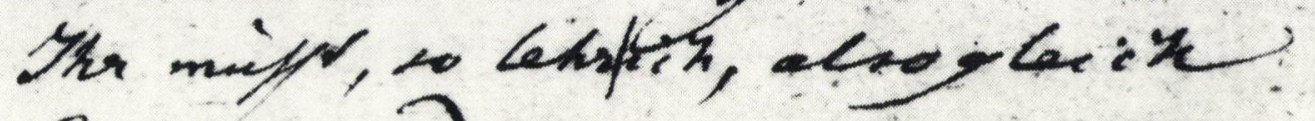
Einer um Den andere verecer. Bemn waint ihs tets bay Eiver yellicke. hie youndet ikr noet immer lidben? Daried dic fonde, da it lis heek

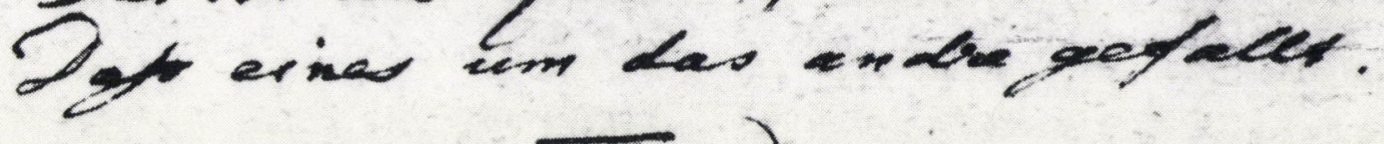

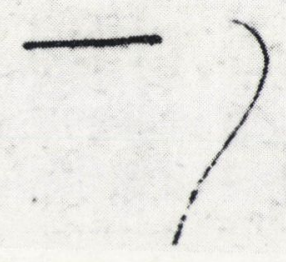




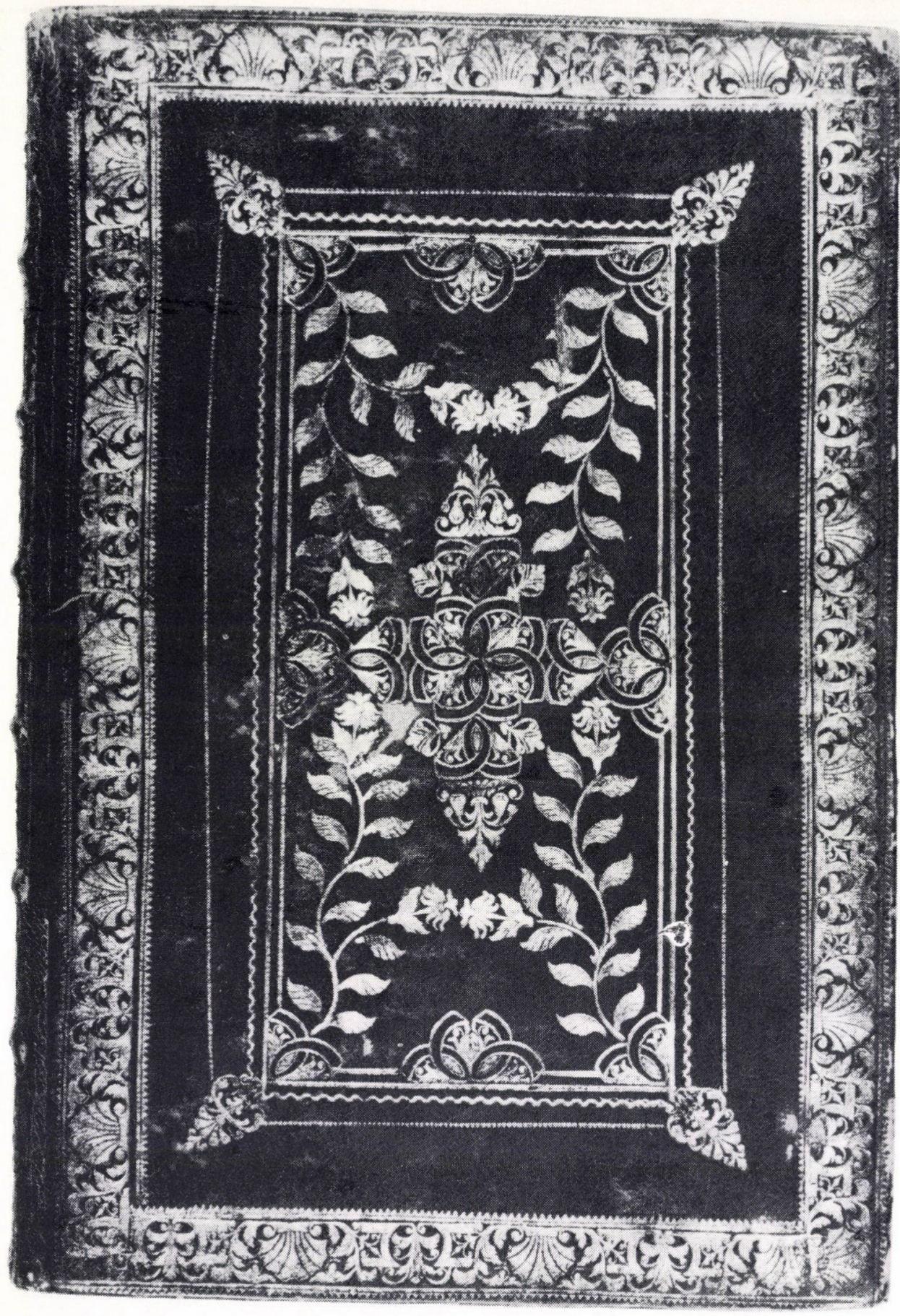

A binding of Nagyszombat from the 18th century 


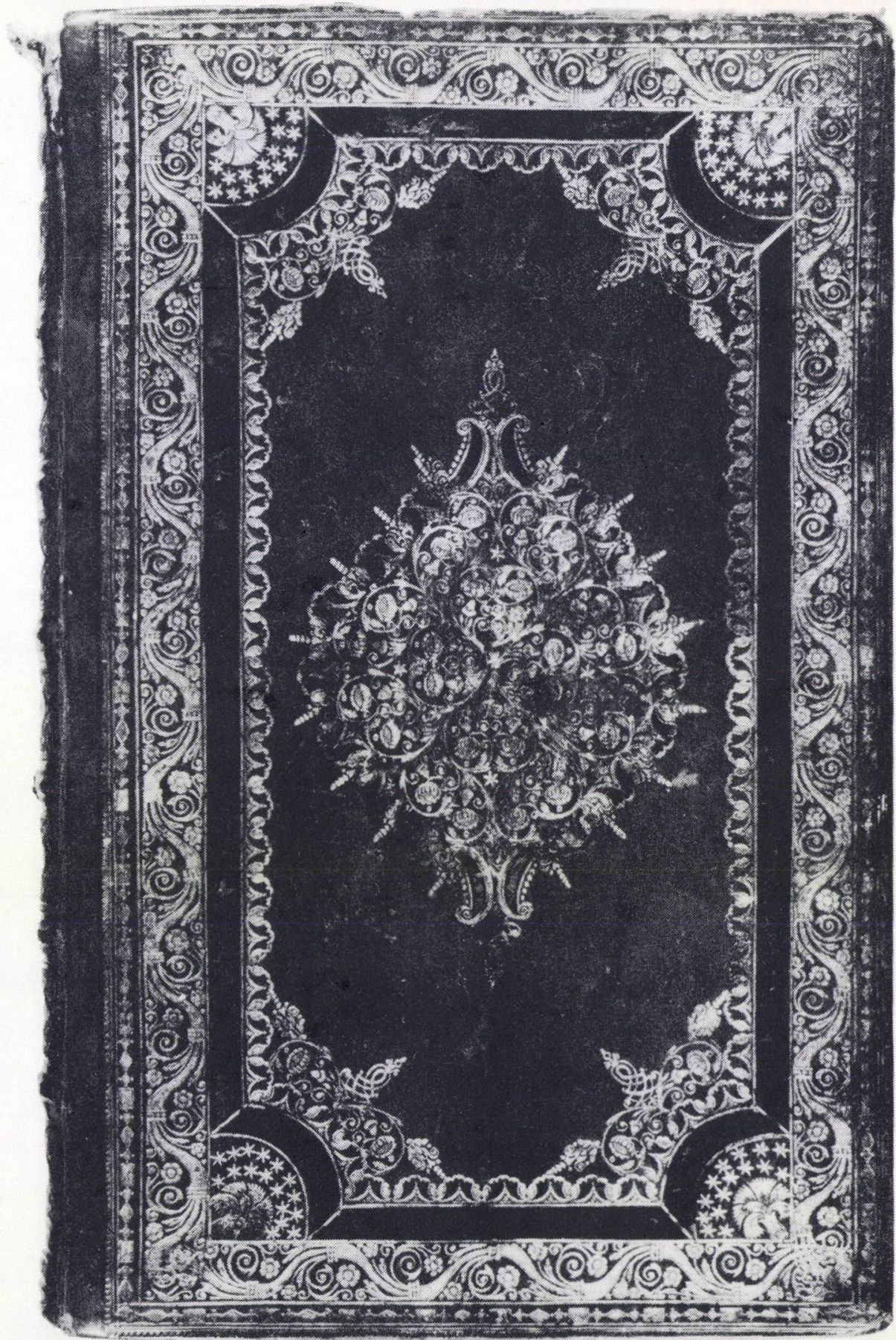

A binding of Nagyszombat from the 18th century 


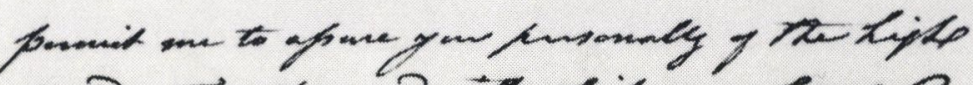

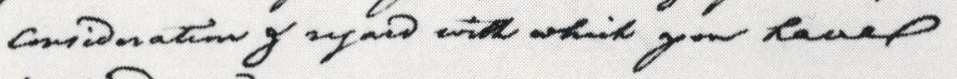
ingtion ans?

q' tan then tap,

Prisongaine

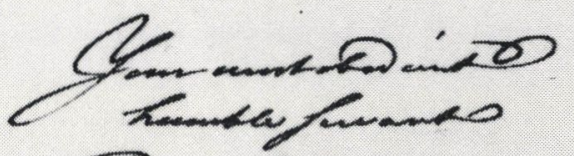

5it/2aneng 1833

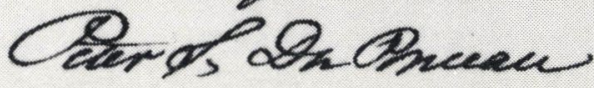

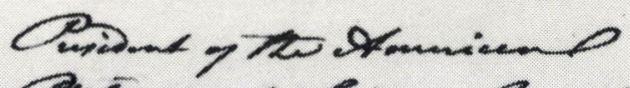

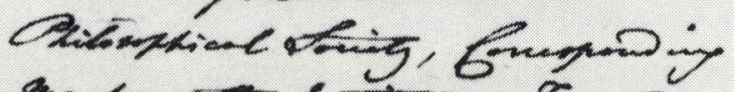

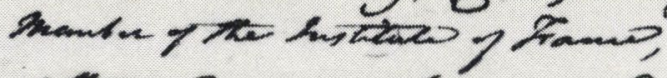

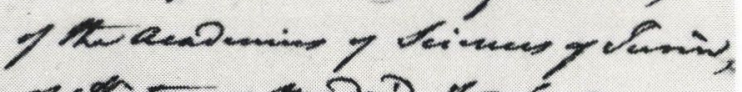

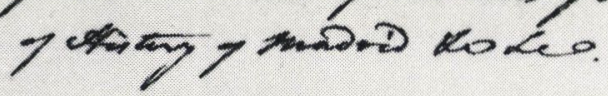

che Thun tape?

remain of teveraymin

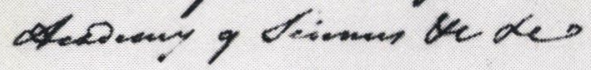

- Yes yon

The first record of the Academy's international relations from 1833:

a letter of P.S. Du Ponceau, the president of the Philosophical Society

of Philadelphia 
Jekinteter Jitsknok Th'.

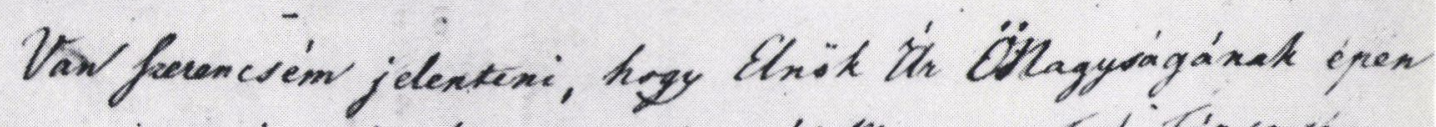
el mai nap' adtam tudtaies a' Mnagyar Jud. 'Tírvasay

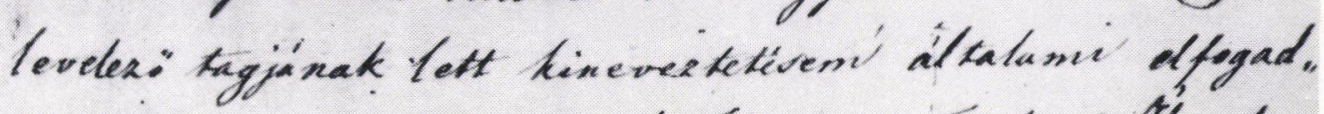

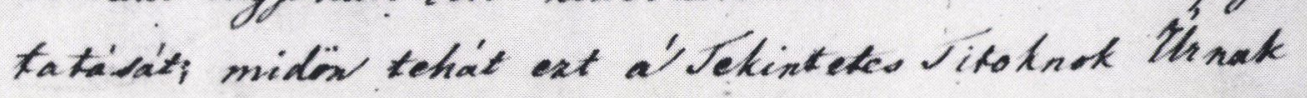

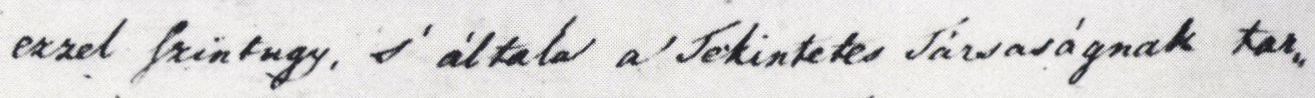
tozi tifateietul bejelenteriém, vagyol.

a' Tekinteses Fitokrok thruak

alízuton jedgáia

Bection Tores

Exai Oet rtain $8 \overline{35}$

A letter of József Eötvös to Ferenc Toldy 
Tekintetes Titohnot tir!'

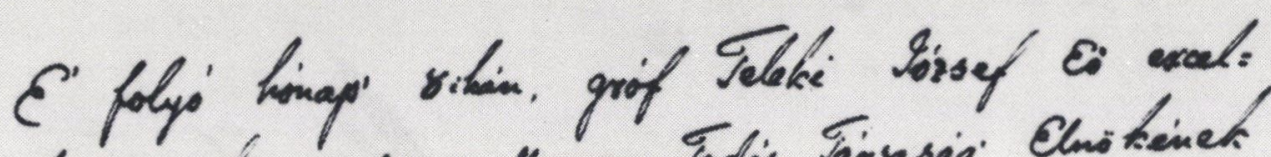

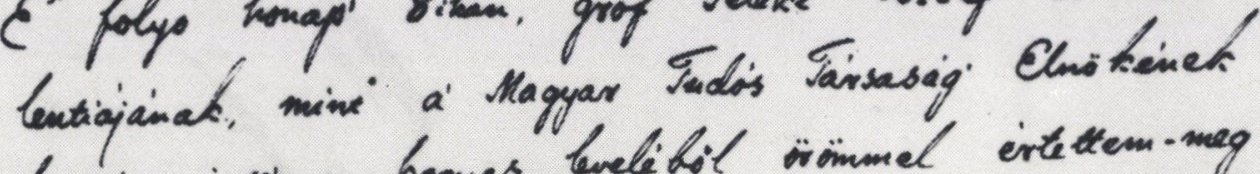

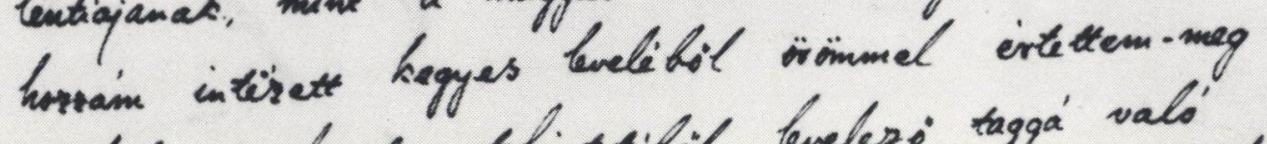
csekily igyekesctem. tekintibil leveless tagga' vals'

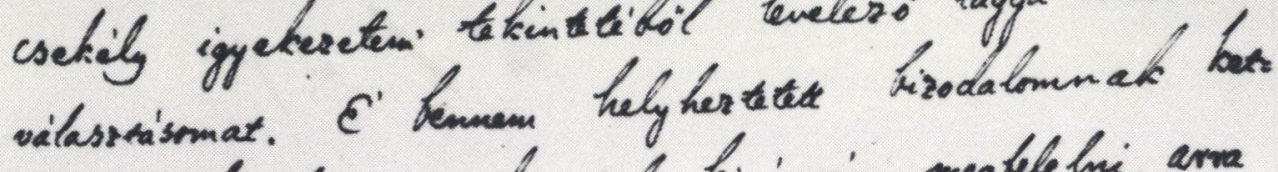
trattit hasafici iggetresetel kivanvain megfelehi, arra

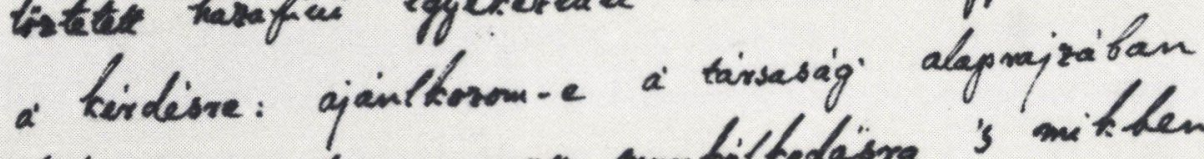

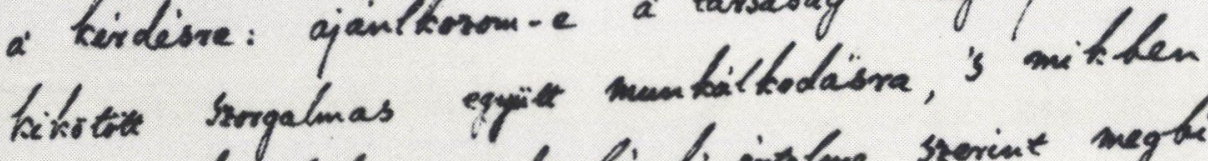

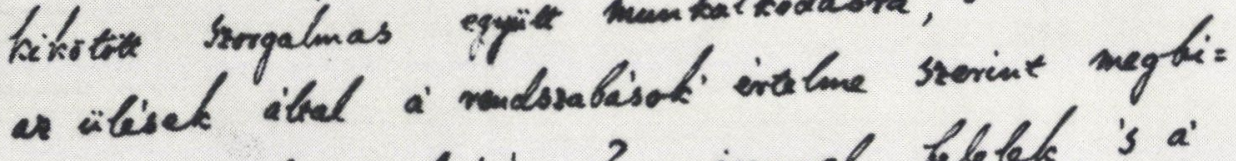
tatom, storgahmas efjainisma? - igmmel fablek, 's a'

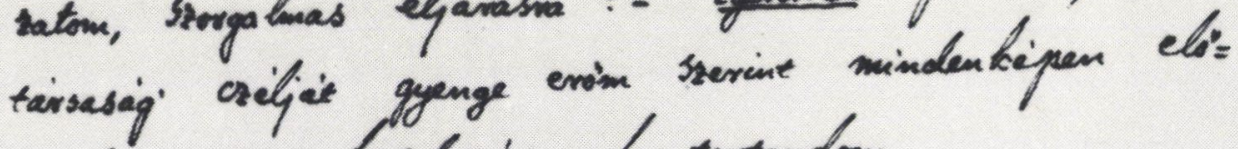
mosditini, stence ksetességemenete tartandom.

Nelly myitatersaisom atain, maganat seives taser.

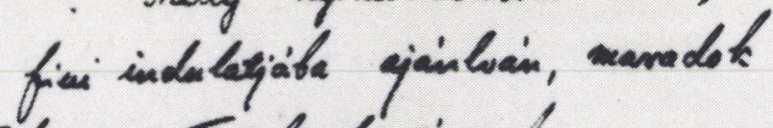
ct Tekindes Fitomot irmak Gestem, 11ik sept. W3?.

aliets sodgaja

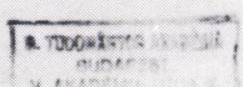

Corkajie Fenyes Eleteh. inguid.

A letter of thanks by Elek Fényes for having been elected a corresponding member of the Academy 
endows

Leotards $181 \mathrm{~cm}$

9. $93 \ldots$

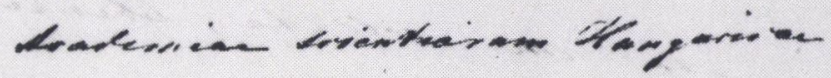

1. S?.

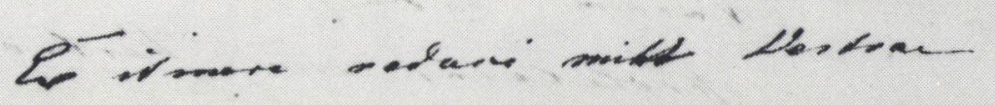

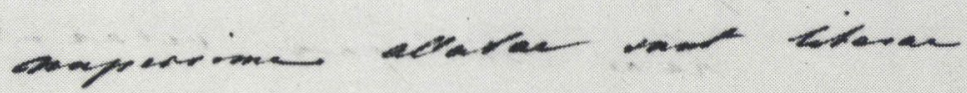

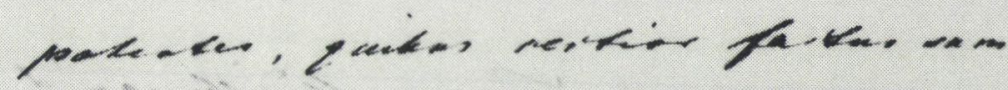

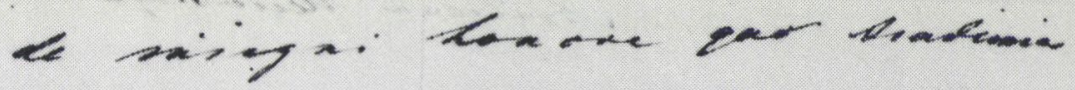

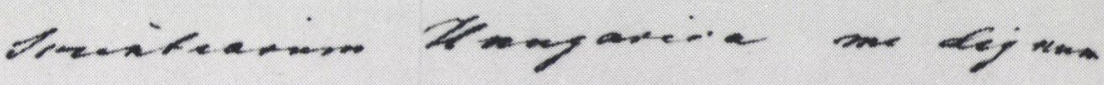

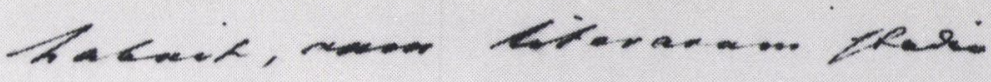

A letter of Robert Wilhelm Bunsen to the Academy 


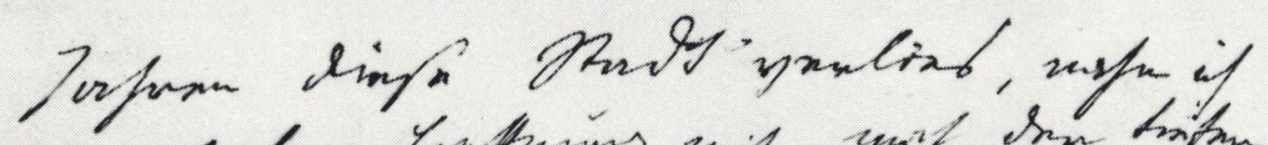

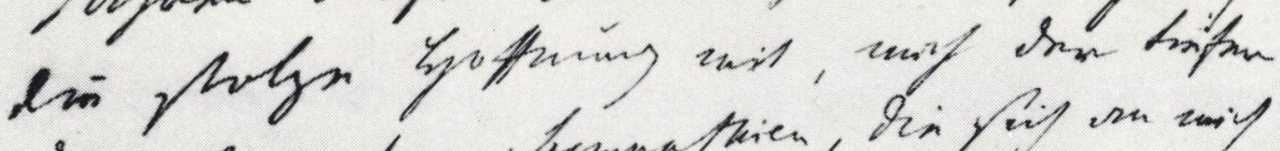

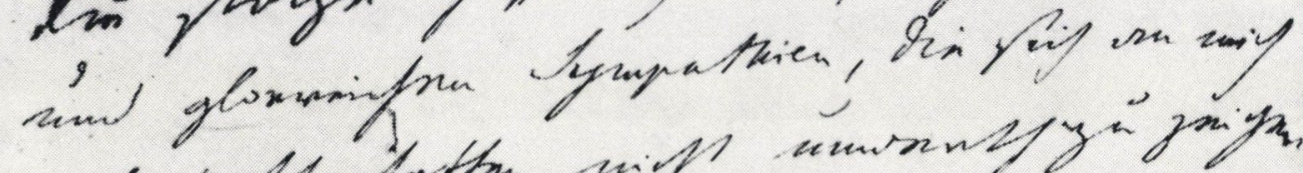

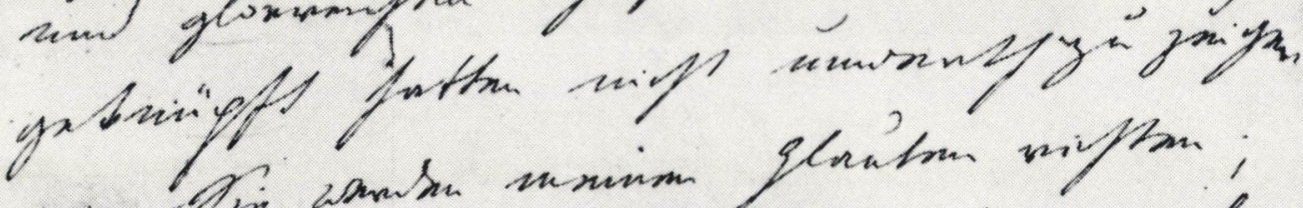

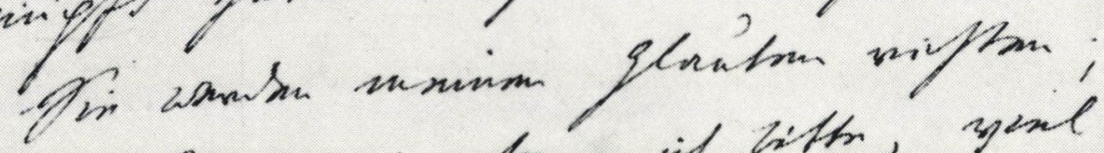

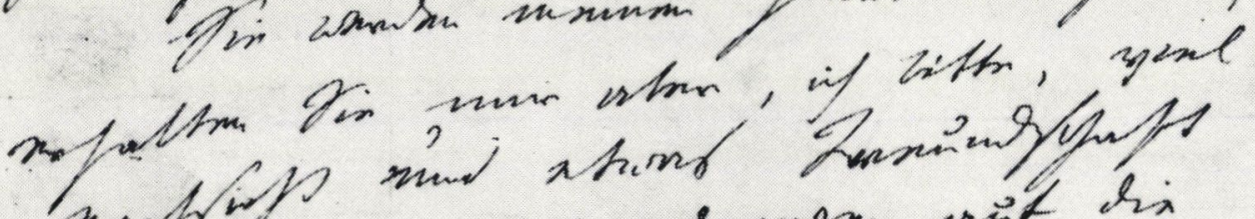

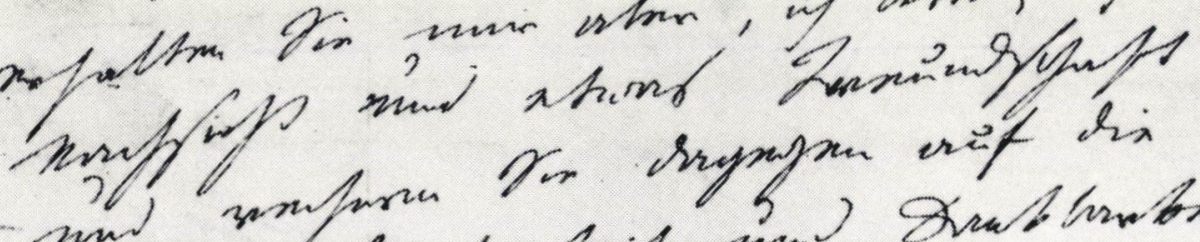

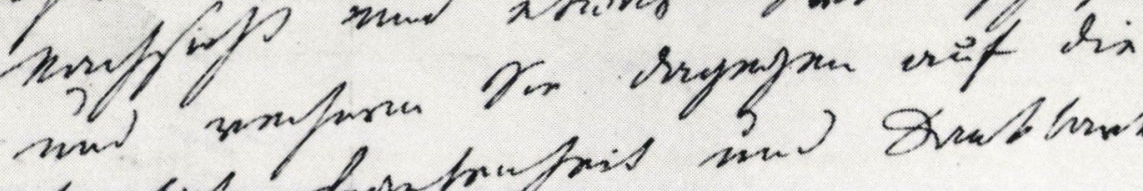

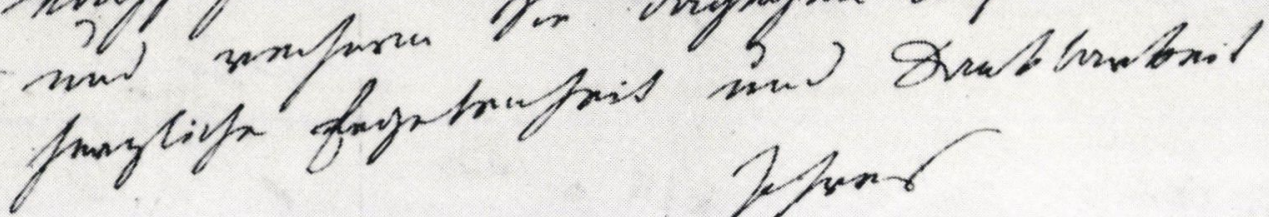
Iyiqawity is mais

A letter of Ferenc Liszt to Mihály Vörösmarty 


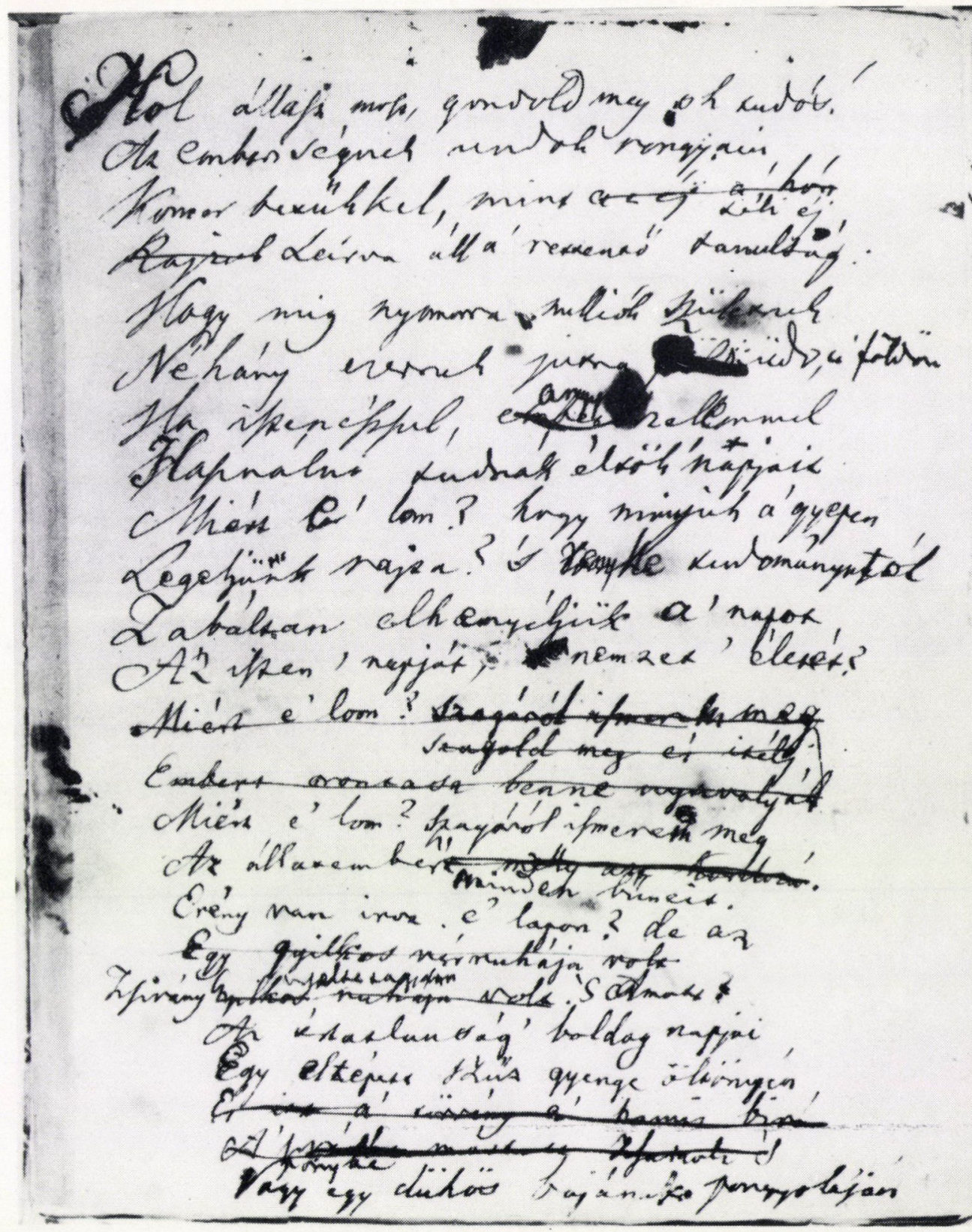

Vörösmarty Mihály: Gondolatok a könyvtárban (Thoughts in the library - An ode) 
Cedd, az ide satoet

tit röpiratkat, ley ögintéb

tinteletem jelëel, yotote

jives indulatoddal, killönösen

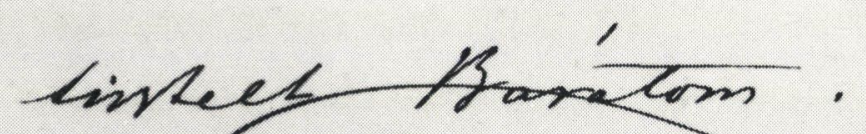

Hai 21846 Eett

A letter of Count István Széchenyi to Pál Felsóbüki Nagy 


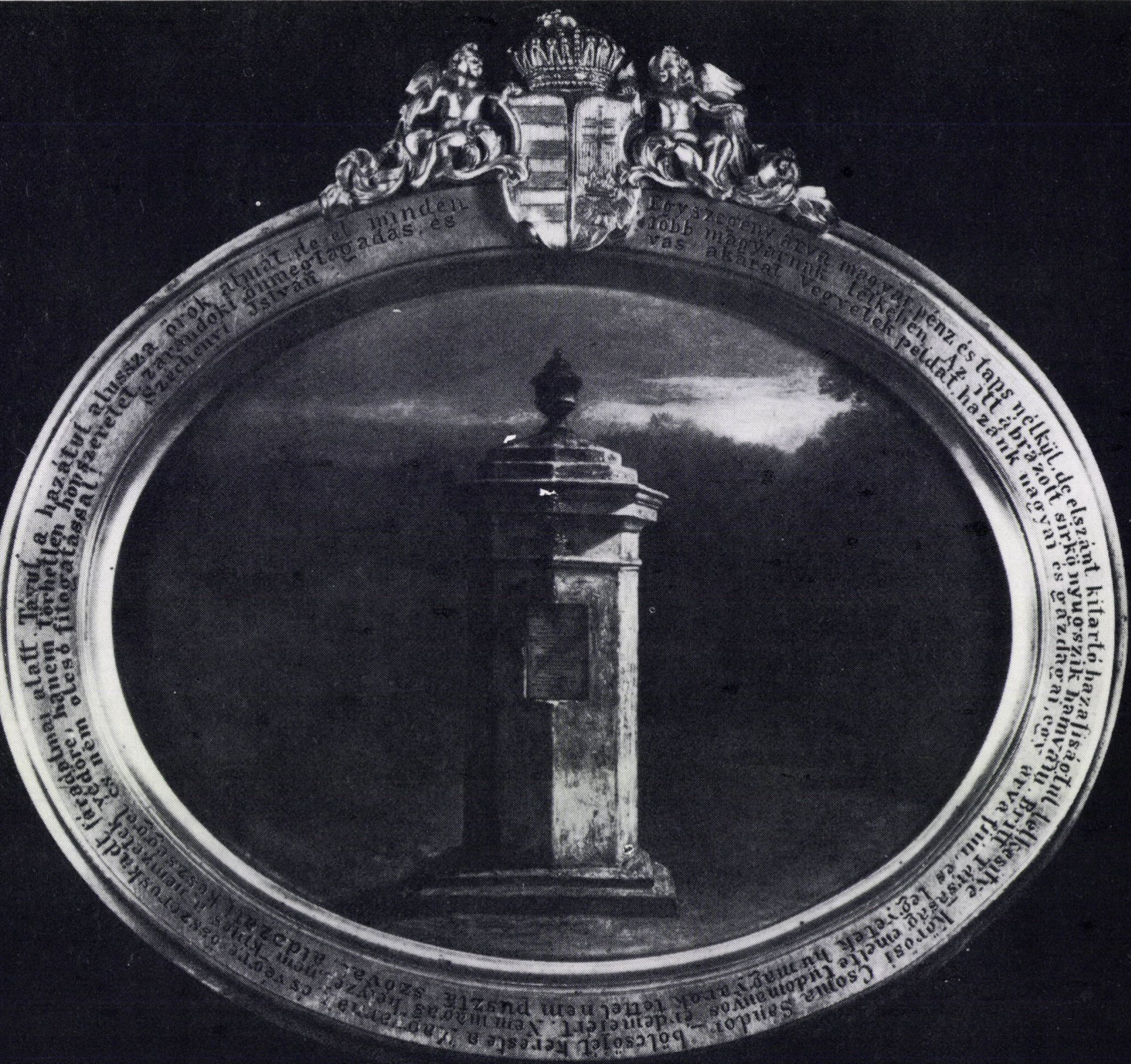

A picture of the tomb of Sándor Körösi Csoma from the literary remains of Count István Széchenyi 


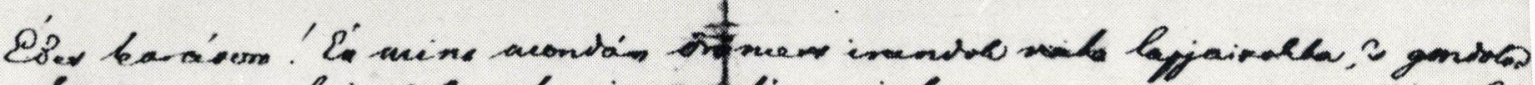

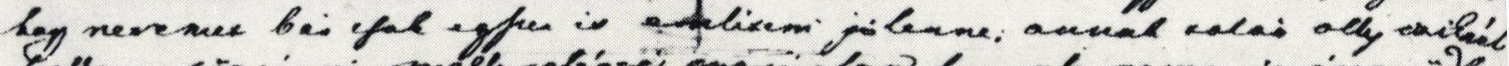

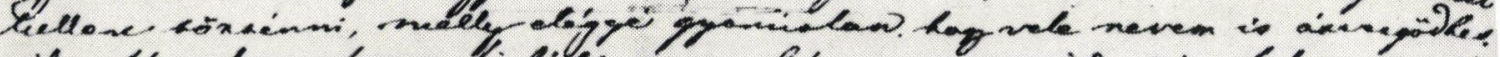

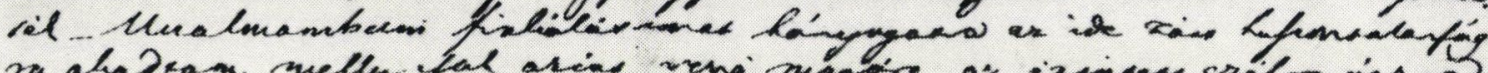

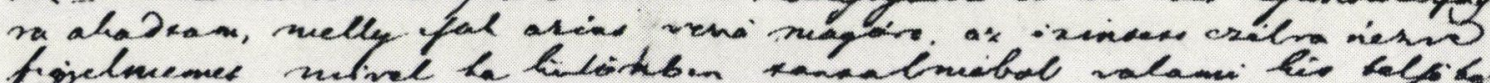

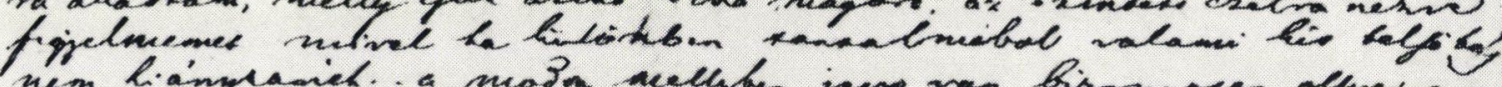

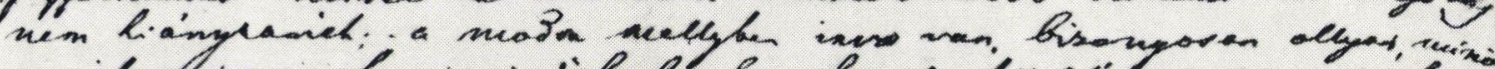

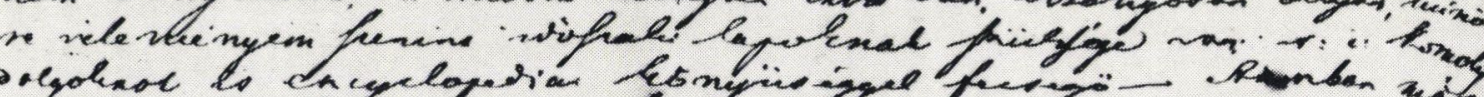

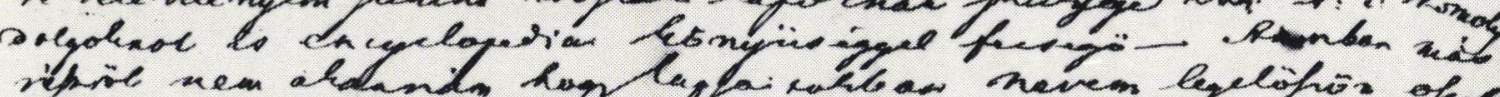

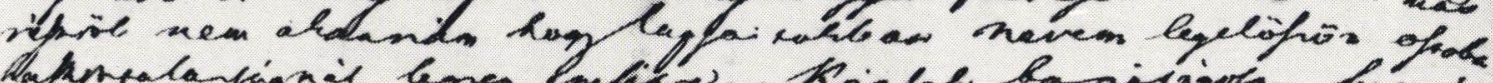

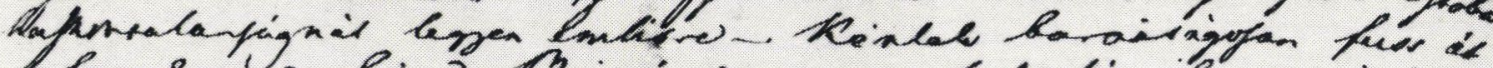

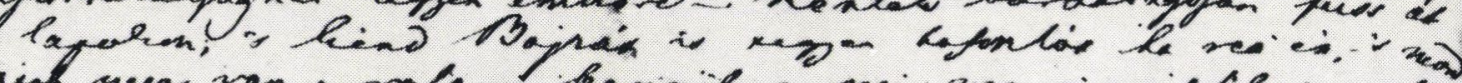

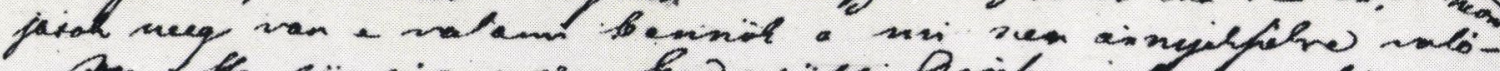

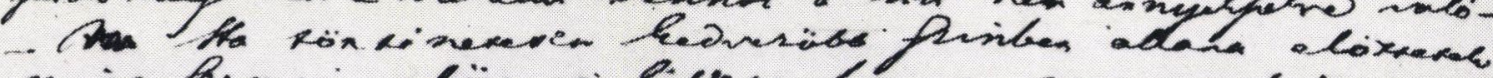

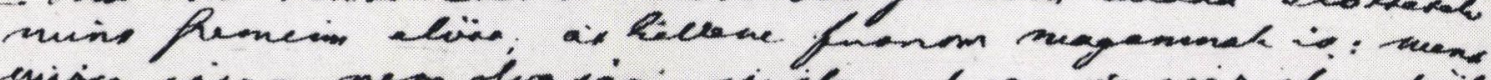

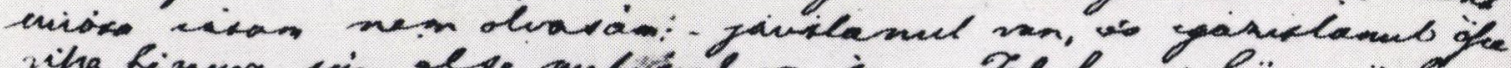

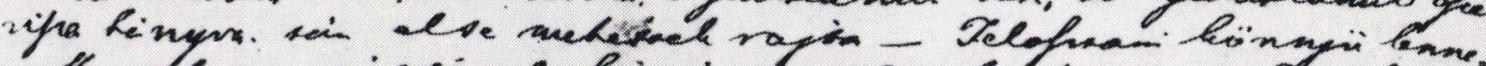

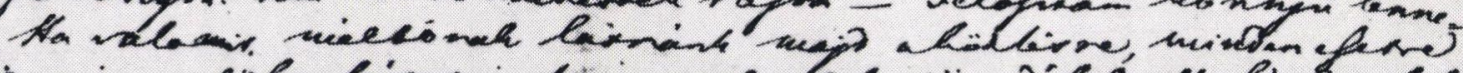

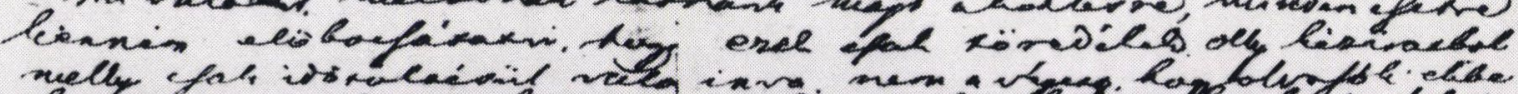

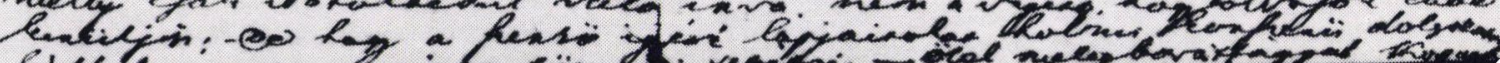

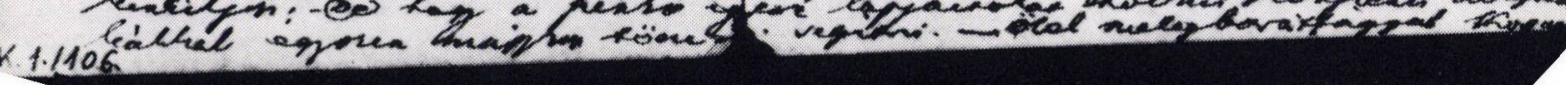




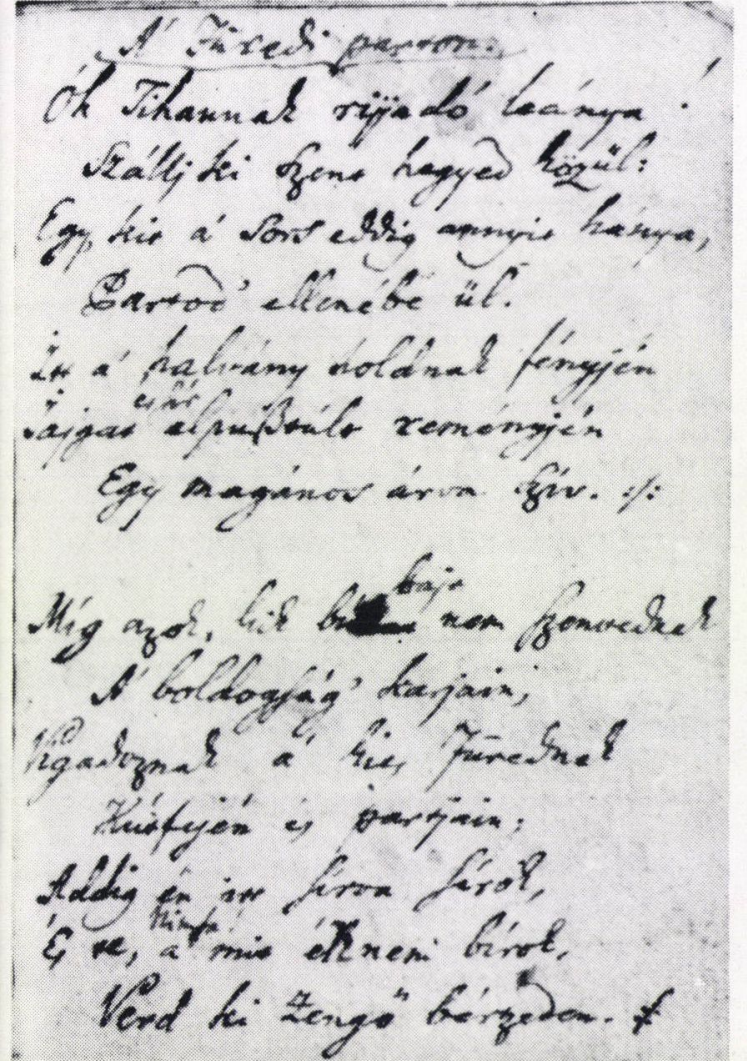

Csokonai Vitéz Mihály: A füredi parton (At the shore of Füred - A poem)

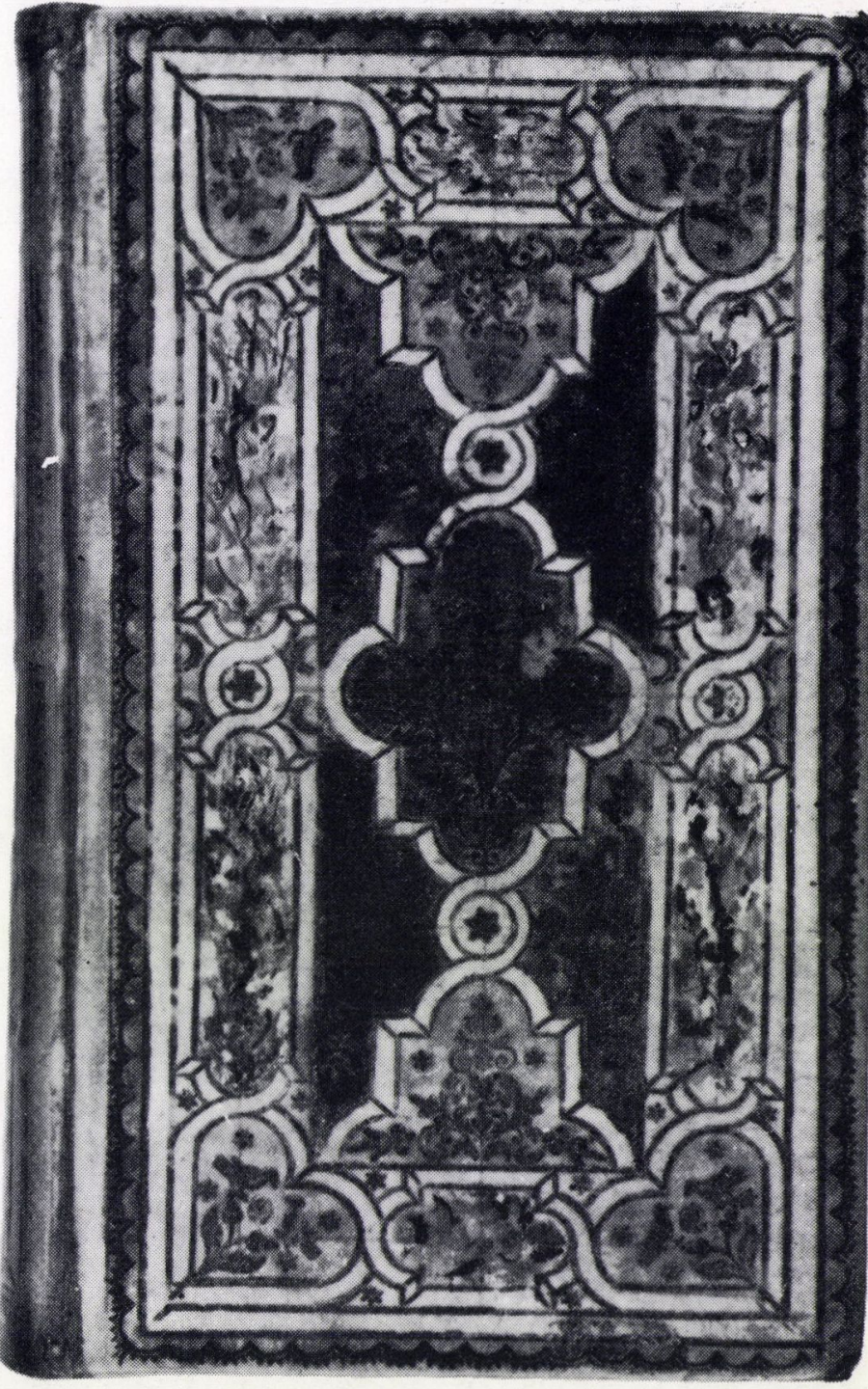

A binding of Debrecen from the 18 th century

4 A letter of Lajos Kossuth to Mihály Vörösmarty 
128 frith

hat .-13. 13.

Royal histitution

Sis

Lad an

7. March 185

Soul very duffy the high ham en which the

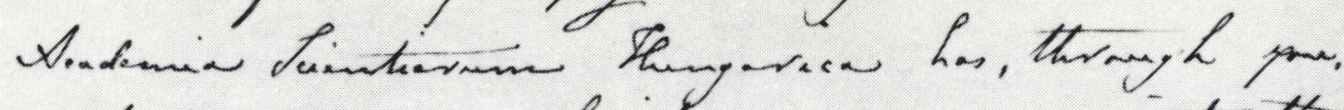

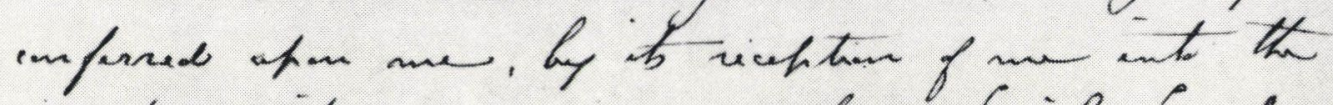

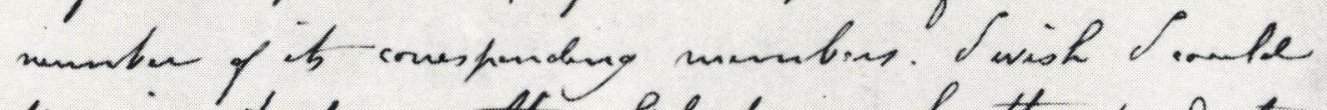

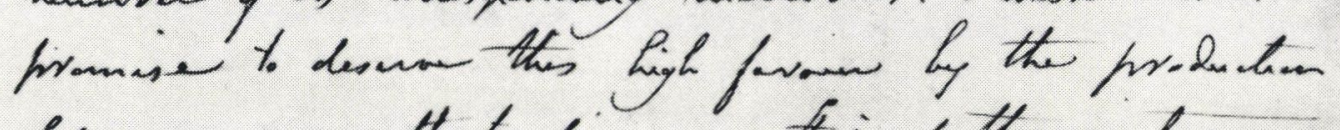
of some new result to dene. At is of the maker of such a stimabut, to mater me wish to do to i hat

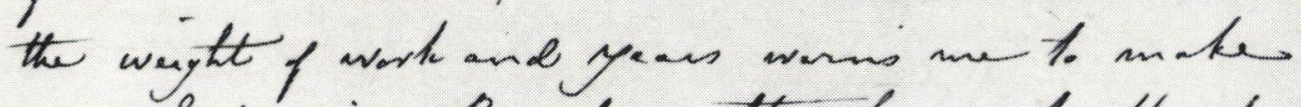
ne rash promises. Pray do me the form en to thank

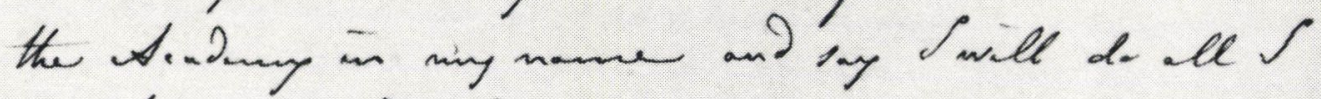
cen to deem it form en

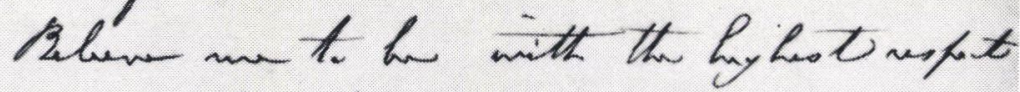
$\$$ esker

Si.

a " M

In mast grater Lumber Lint

M. Tramming Sly

Heraldry

A letter of thanks by Michael Faraday for having been elected a member of the Academy 


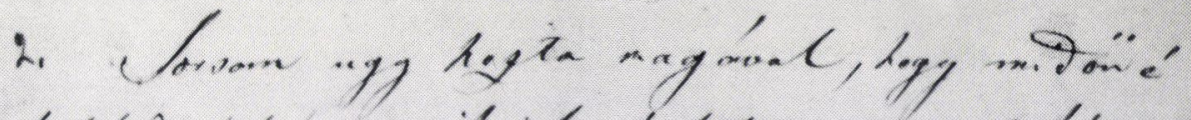

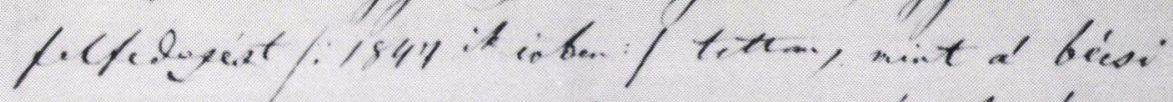

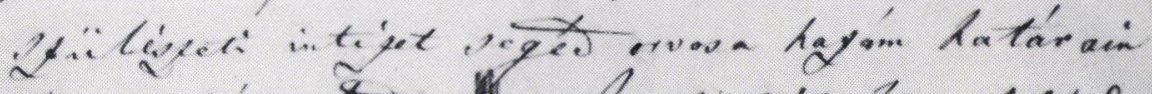

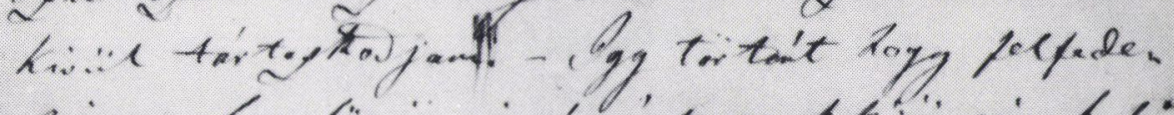

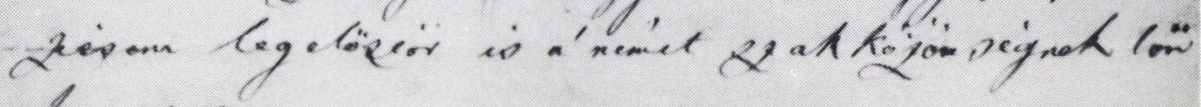
benutation.

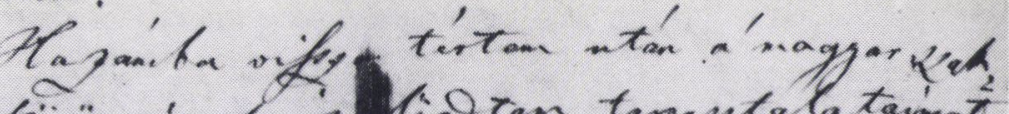

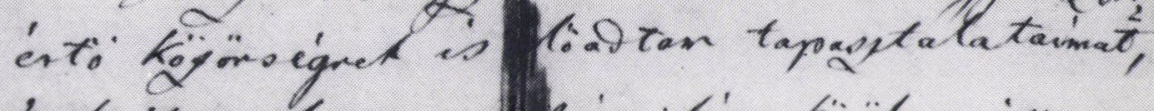

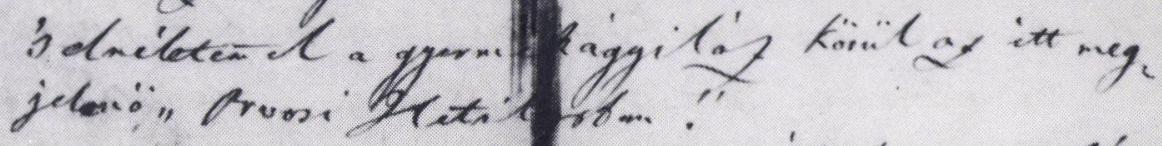

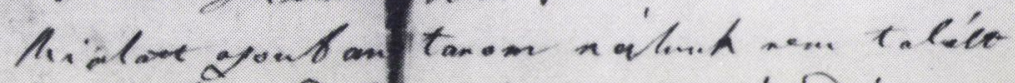

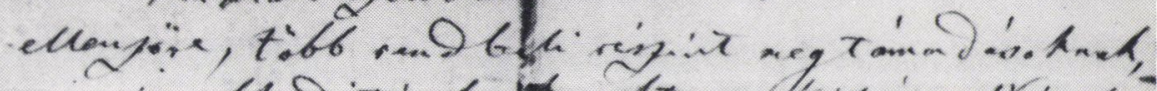

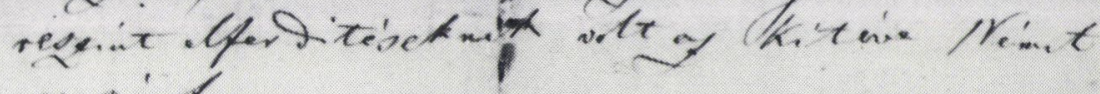
wrog to.

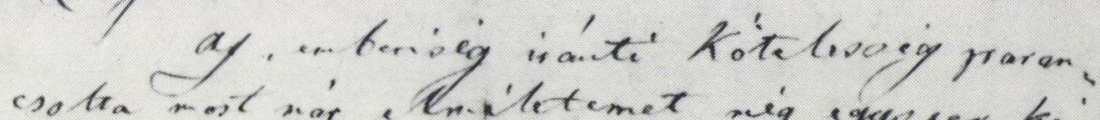

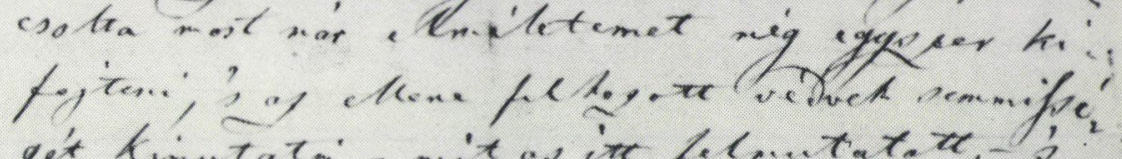

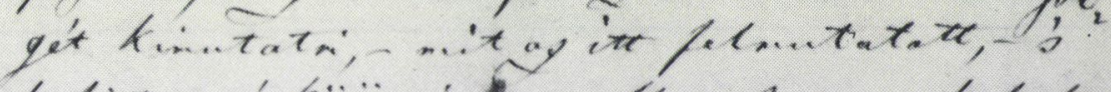

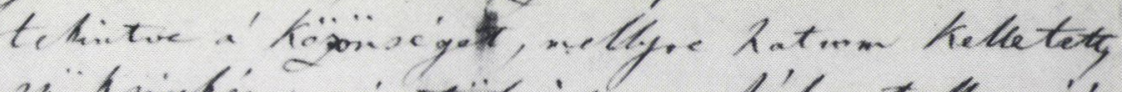

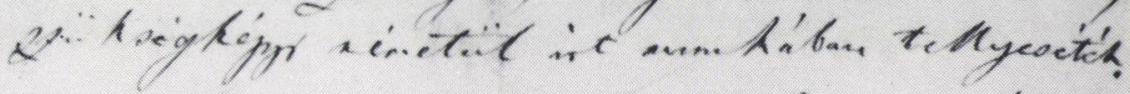

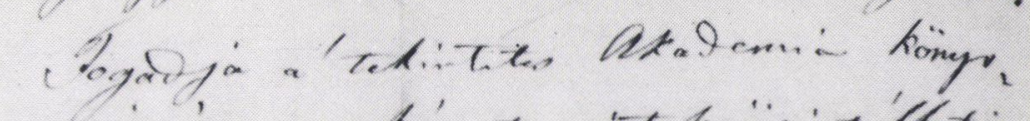

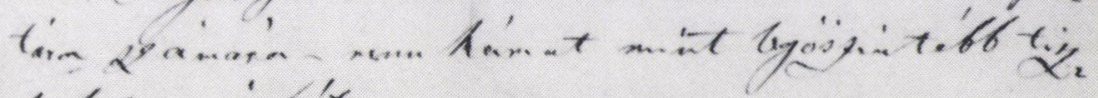
tele to... ject't.

Jesi, Itha:

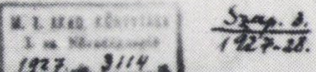

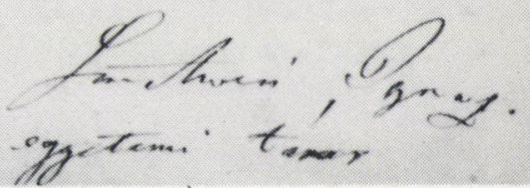

Ignác Semmelweis' report to the Academy on his discovery 


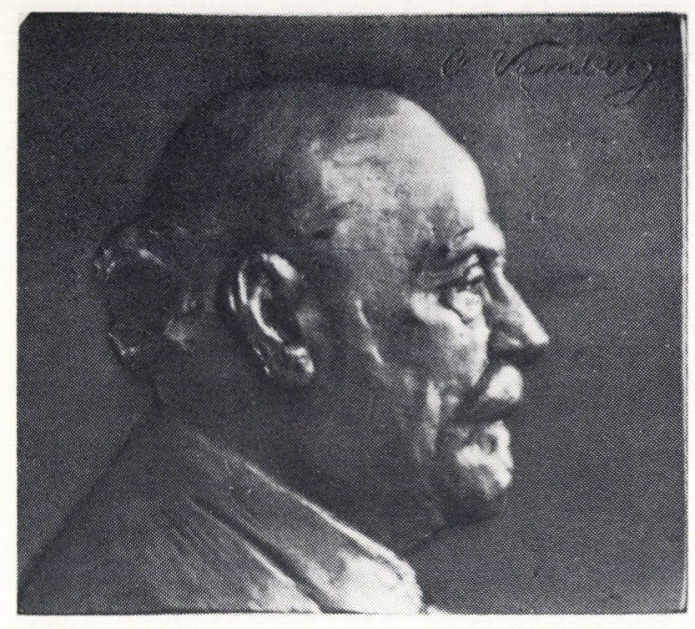

The Ármin Vámbéry-medal
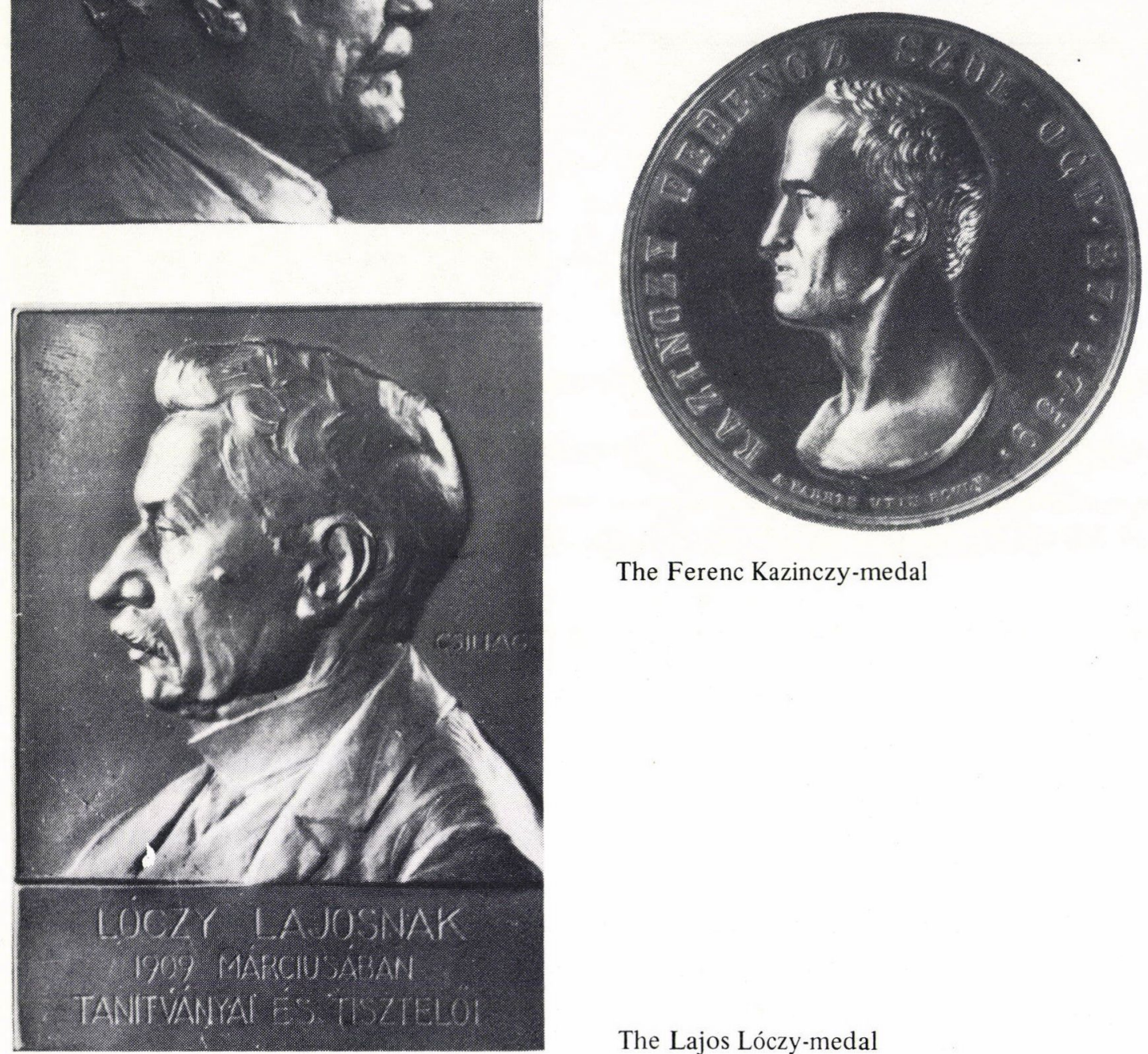

The Ferenc Kazinczy-medal

The Lajos Lóczy-medal 


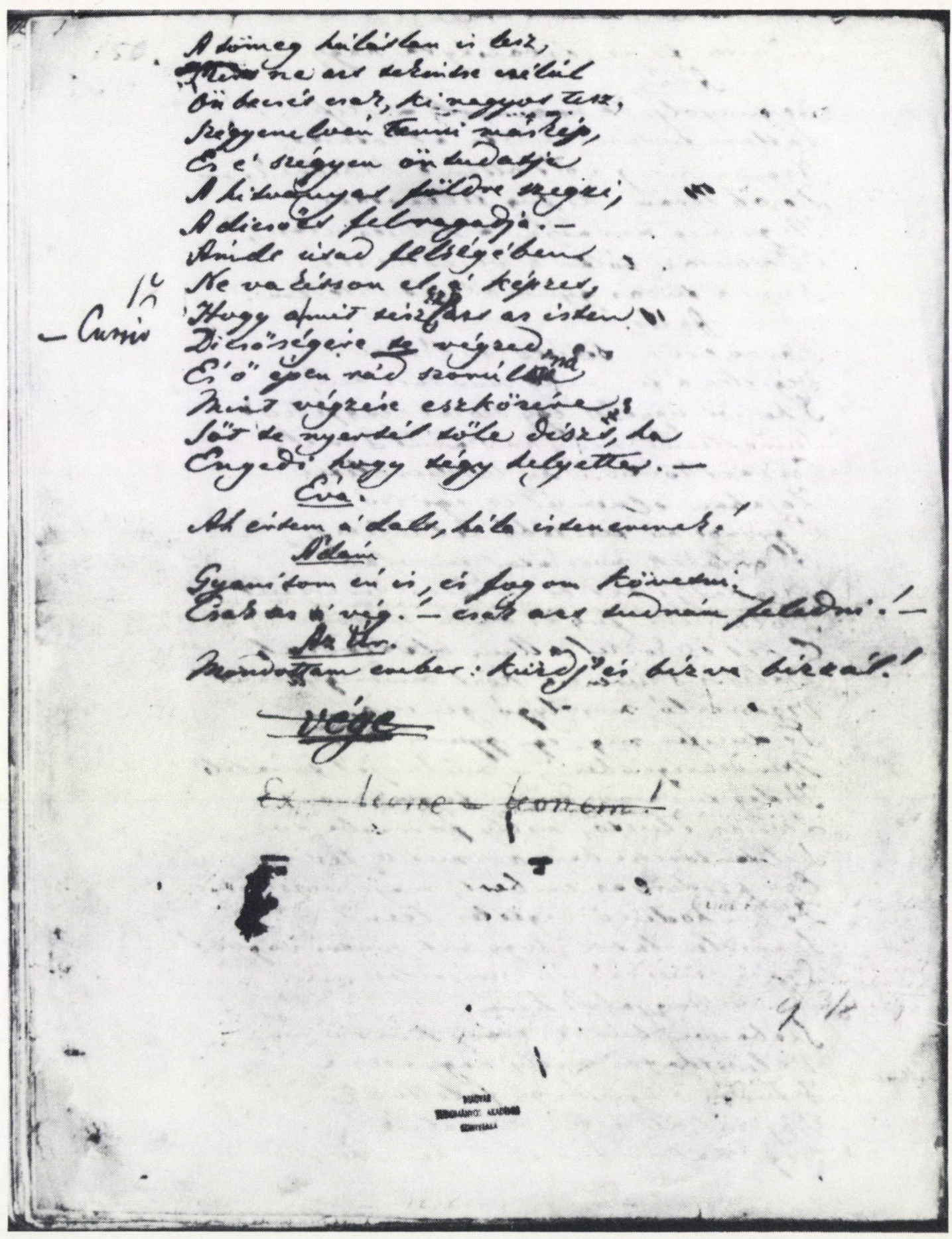




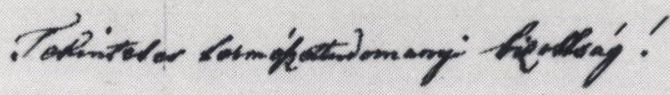

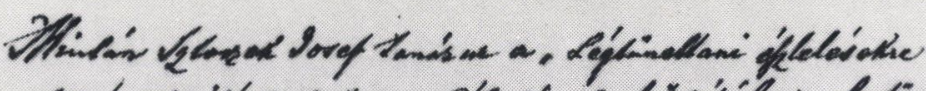

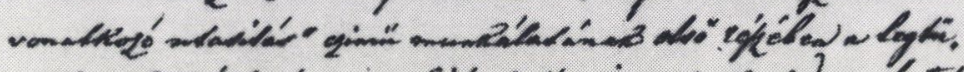

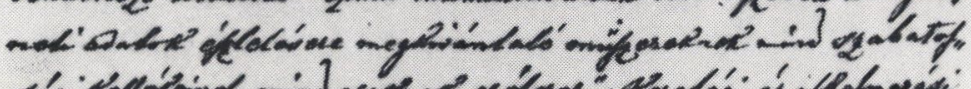

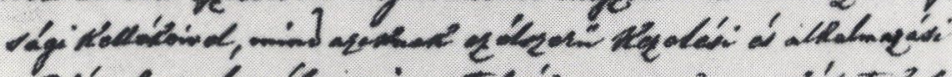

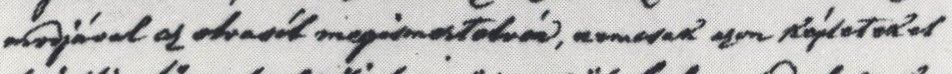

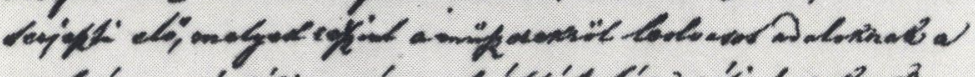

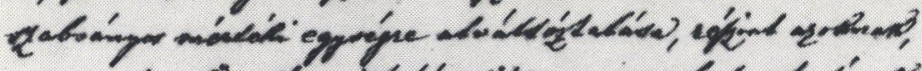

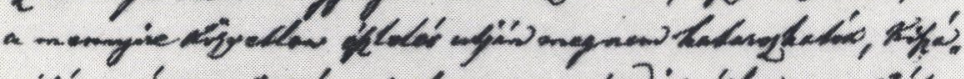

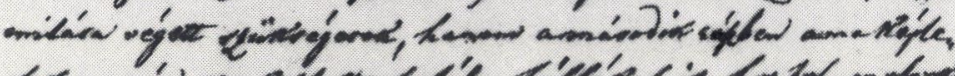

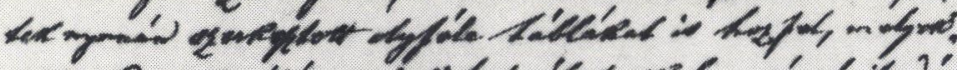

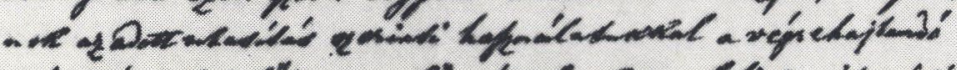

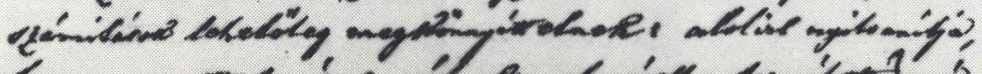

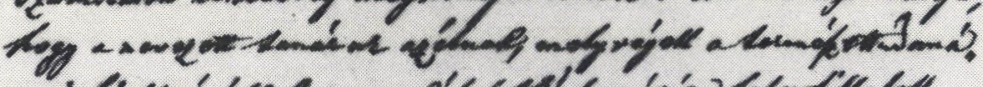

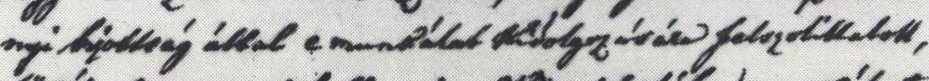

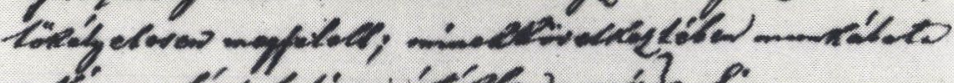

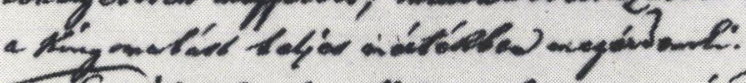

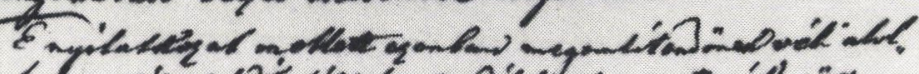

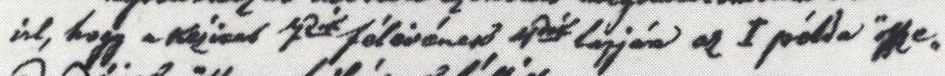

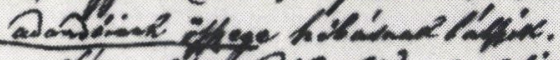

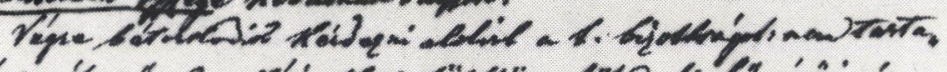

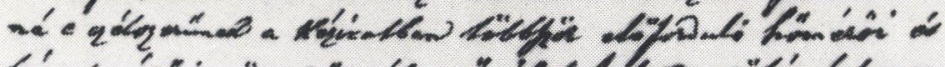

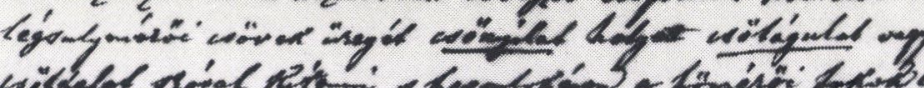

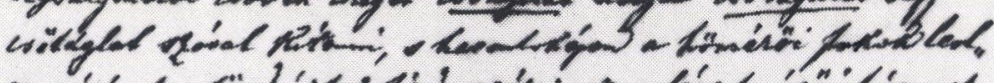

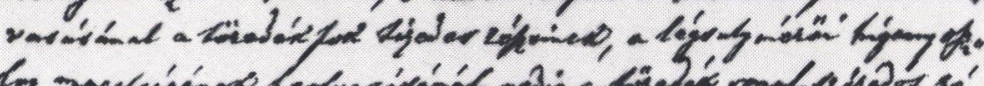

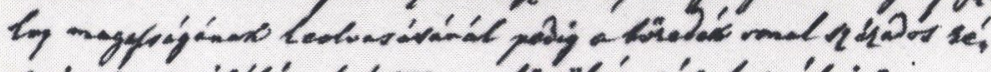

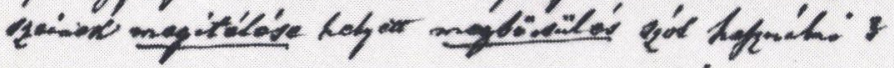
boft gminoth' 20s 186 .

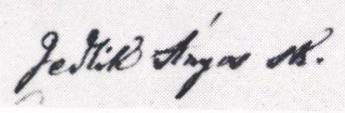

A report of Ányos Jedlik to the Academy's Committee on

Natural Sciences 


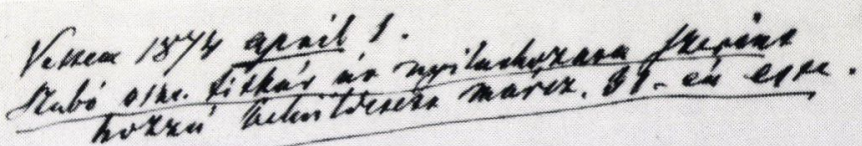

$288 . \pi$

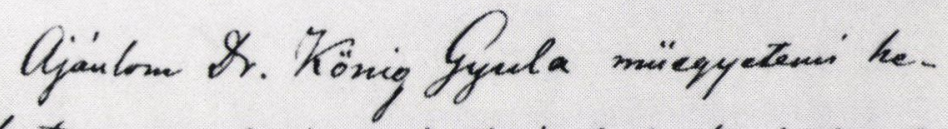

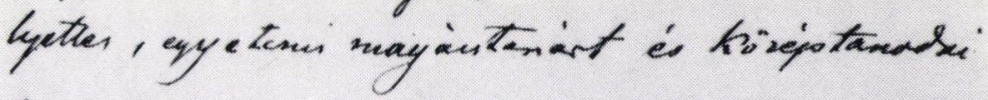
tanarkipesdei tankint a N. 1. akademia III mitalyaba leveleso" taquil.

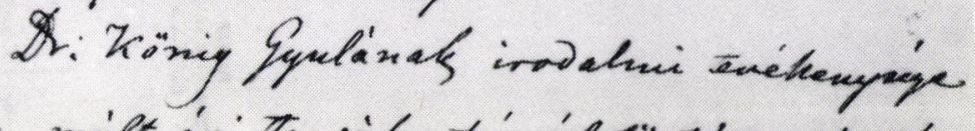
a milt evi taguitar tainal Iörteit y'ánlá alkalmaival tiizetem felumbltitott, cher a tefolyt is ben egy istehosisl crat-er

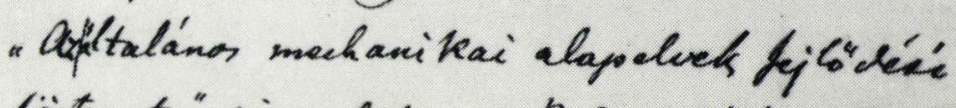

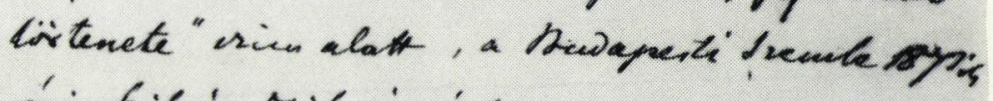
évi bih és Yils riamá baen.

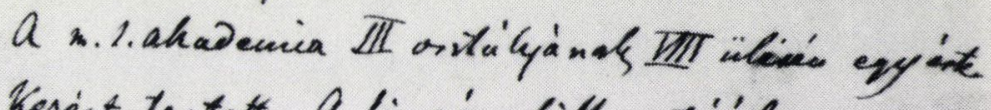
Keseit tortot . A lineár differentiel equenteter dmileteng"

Hitari: Loraing

A letter of Loránd Eötvös recommending Gyula Kônig to be elected a member of the Academy 
Appendix,

Cientiam pratii absolute veram exhibens; a veritate aut falsitate taioma tis XI. Euclidei (a priori haua unquarm decidenda) independen. tem; adjecta ad casum falsitatis quadratura circuligeometrica

Auctore Iahanne Bolyai de Baclen Geometrarum in Exercitu Caesareo Regio Austriaco Castrensium Capitane. Agropoli sive Maros-Täadrhalyei Iypis Collegü K892. - TOE

The hand-written front page of the Appendix by János Bolyai 
com pagaie que vour pris ides.

Le ne sanraig von dire gombies if uns remible à ce grand homens. Il mest d antant plus précienx qu'il s'attache an nom illuptre de Bolyai et gu' il vient d'un peuple pour lequal j"ai 'tayours resen ti me vive sympathie deping m voyage que,'mifait en Hongrie en 1877 et qui m'a laissé d'ineffecably sowenis.

Verilles agres, Monient le Prinder.; $l$ 'asurance ds ma consider ation $l_{2}$ pluy distinguee,

poing aly

Jules Henri Poincaré's letter of thanks for the Bolyai-prize 


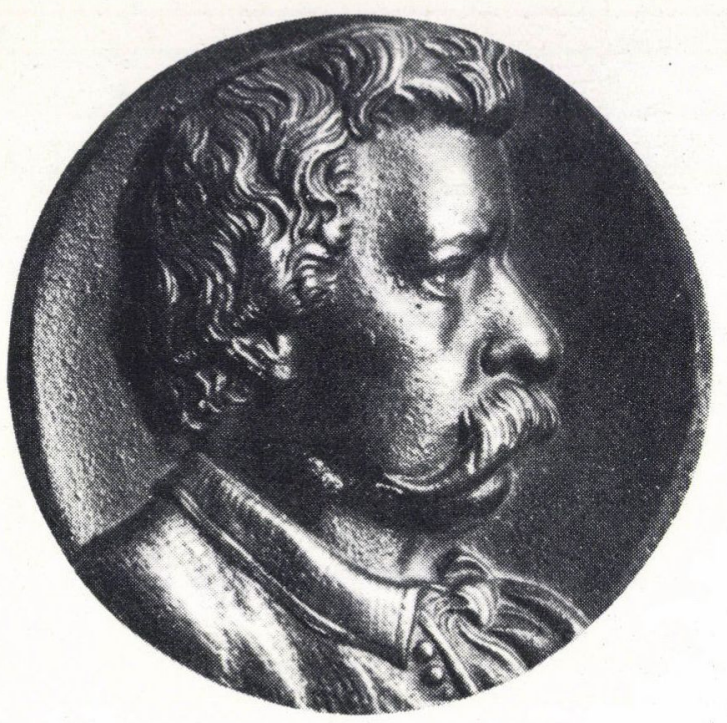

The János Arany-medal

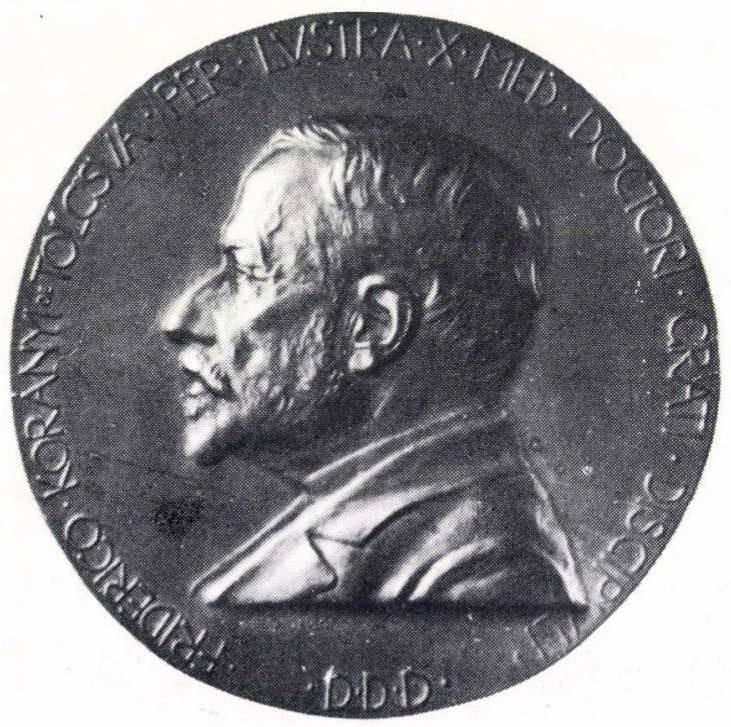

The Frigyes Korányi-medal

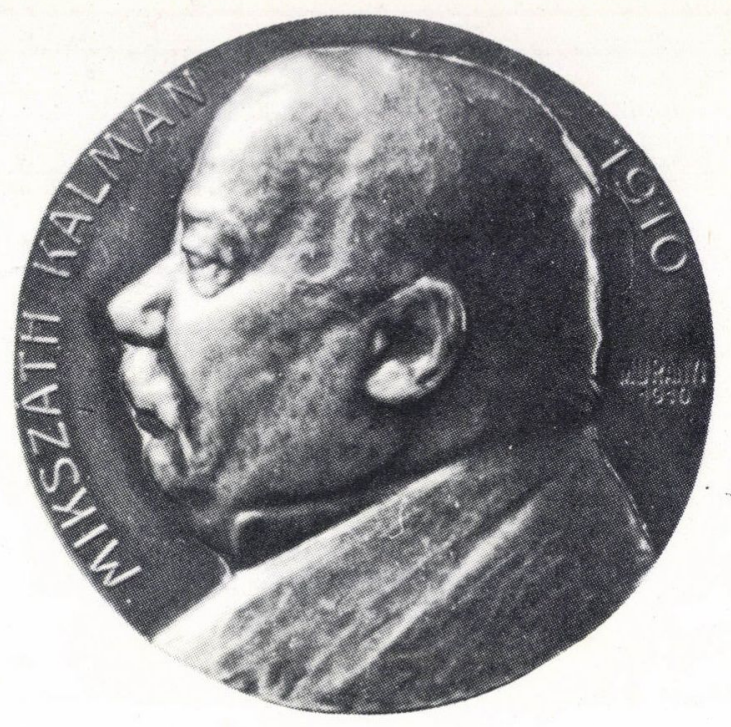

The Kálmán Mikszáth-medal 


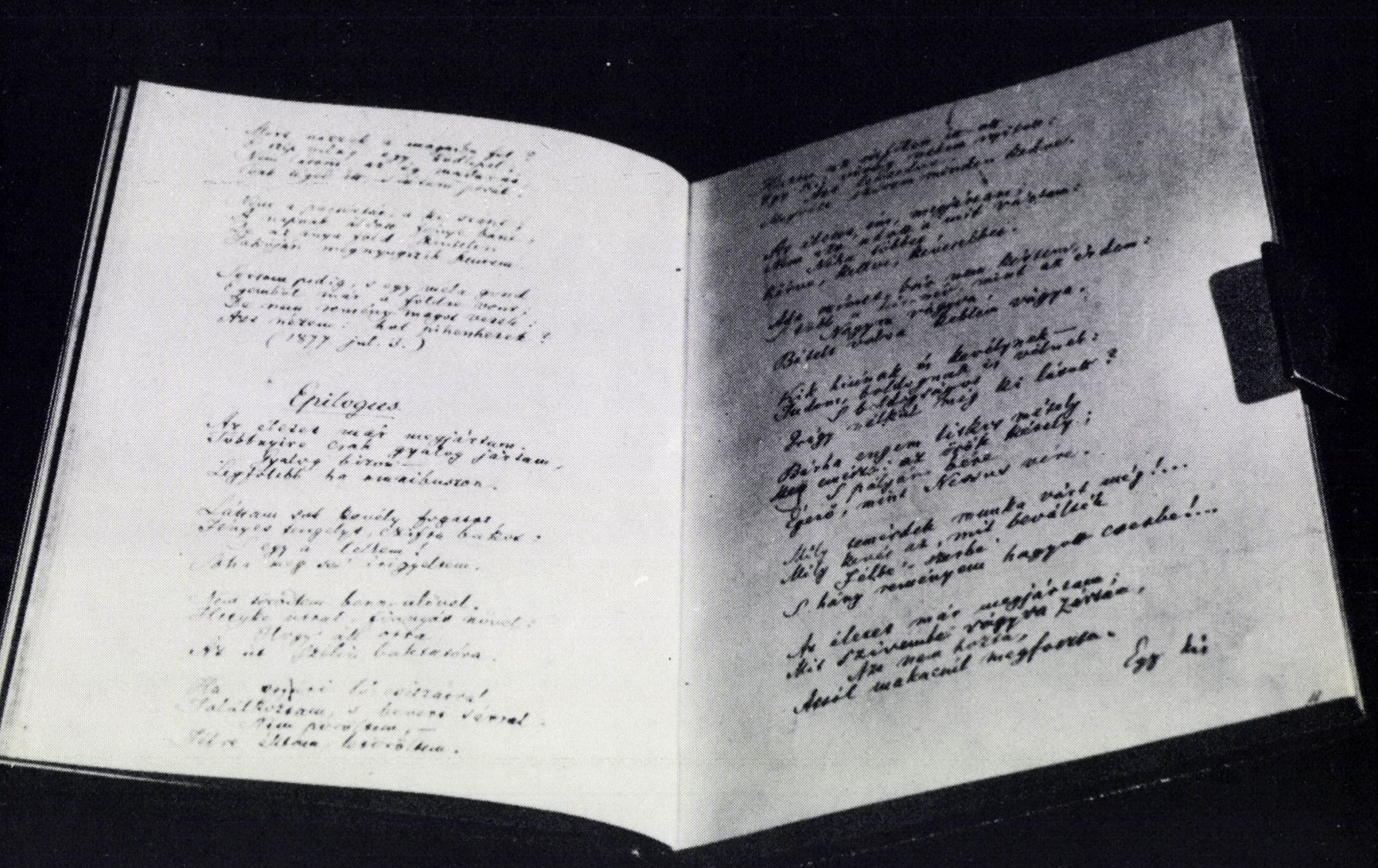

The so-called Kapcsos könyv of János Arany (The book with a clasp) 
40.

opt.

Ophalia, nid we'sue ast ohrjien.

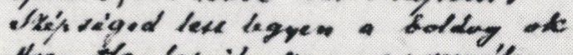

Nogy Hanles, ily *aners! reonellem, igy Eningod a ió deba nithaki,

"kindkew"L"k deurallevire.

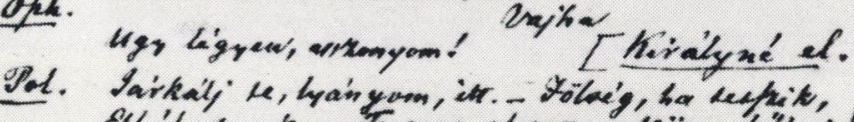

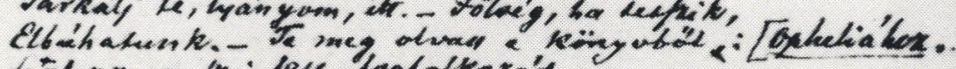

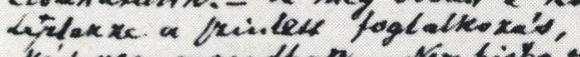

Wert ragr magadban. - Sem kiaba mondja'k -

Sok ceide wan rai- hagy ajketar enckexal,

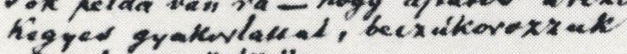

Llaga' ex ölï̈̈̈.

Mir. [Xelve.7 Magyen iget:

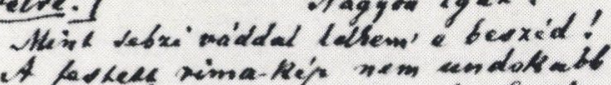

At forket nima-Nein nem andakebs

thox kepers, mived kenike-fenite,

Pol. Oh mily methez ko Hollow lejkeit:

L kiraly is porostius el.

\section{Hamlet $\rightarrow "$.}

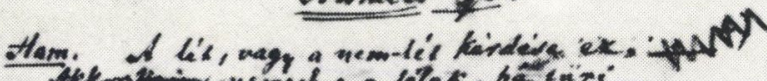

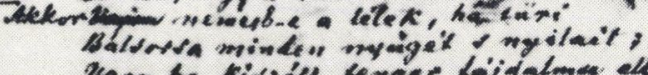

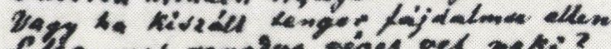

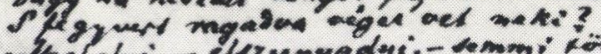

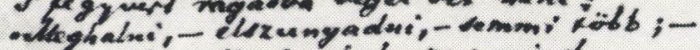

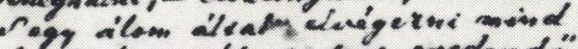

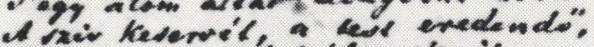

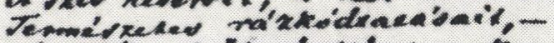

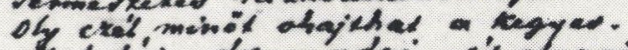

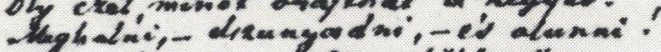

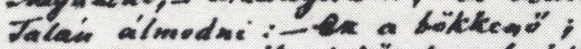

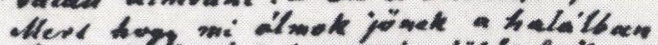

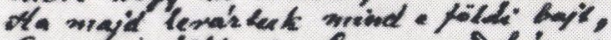

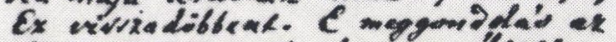

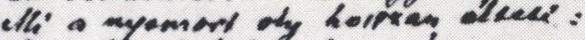

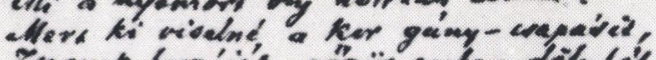

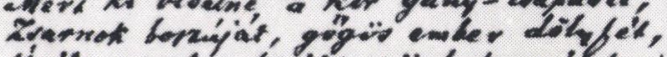

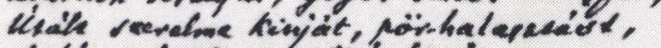

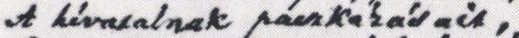

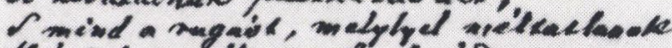

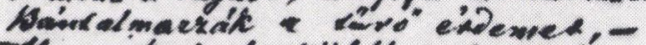

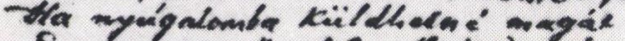

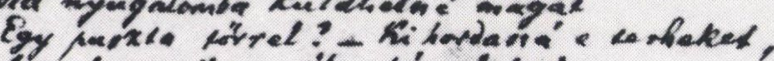

Intadera, nyigrae elle fairedelucin,

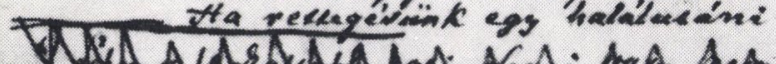

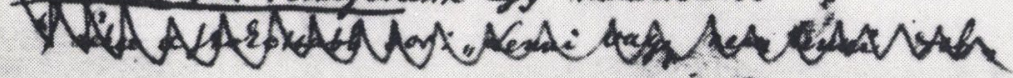

A passage from Shakespeare's Hamlet translated-by János Arany 
11/2. ar in hadrerregem. Fiatalot.

Fouri. pairatan habsecegem, rem boj ha meghabol. Enyein ap orajag

$S$ a liuter

a legfentebl hivatalor: tia meghalor.

Eit orosan cirialtam:

Jojjeter, Ri.

Nilammil binöscbber.

spoblal is hiverebber.

gobbiris jobbar.

Fiatalor.

TE vaptor as in ongagom

$S$ tieiter log in minden,

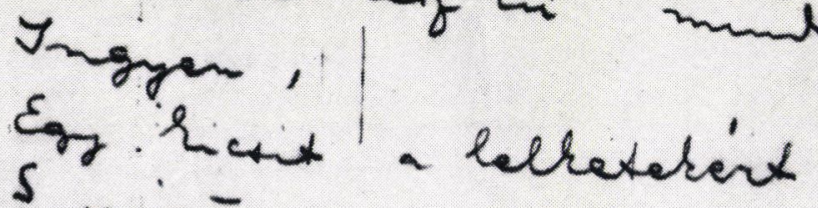

4 Egy Racit a

clïe, diaiga habreregem,

Ady Endre: Az én hadseregem (My army - A poem) 
Guk is lis.

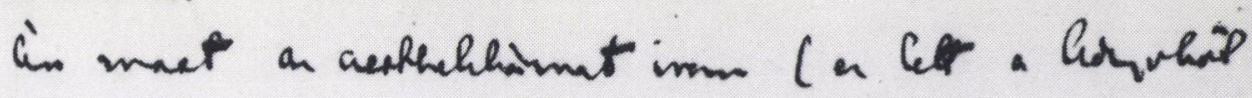

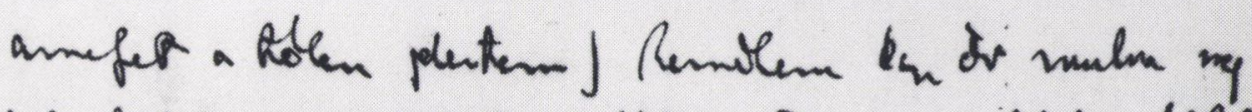

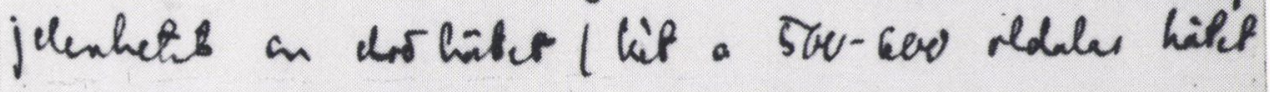

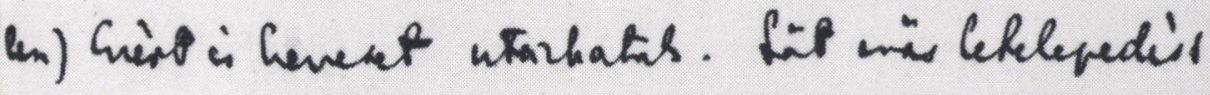

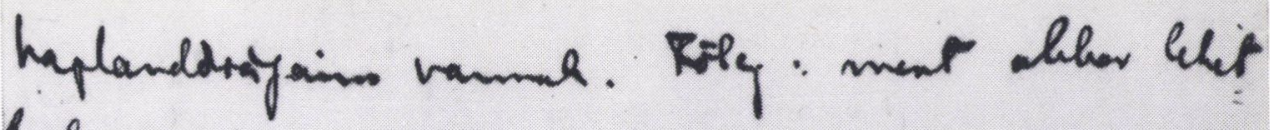

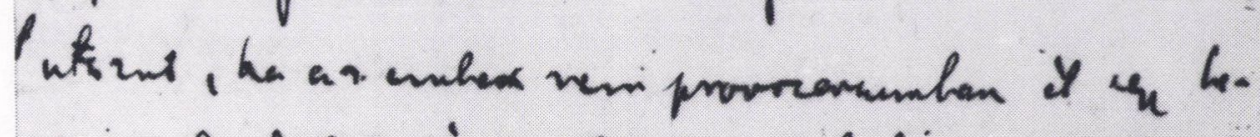

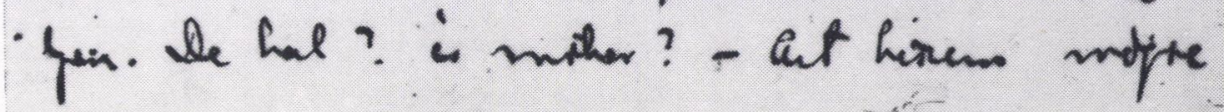

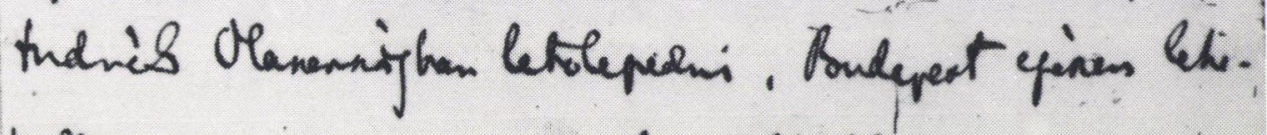

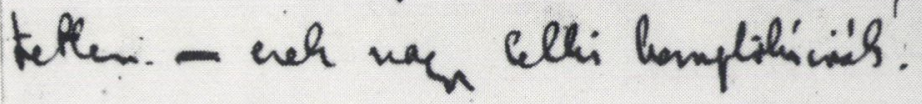

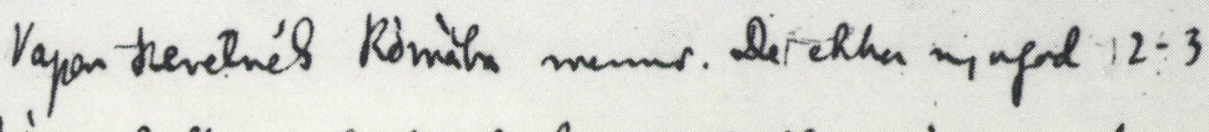

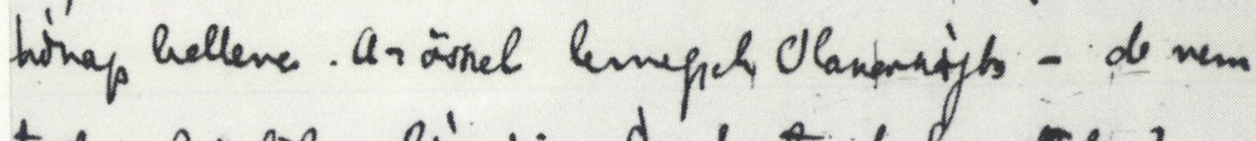

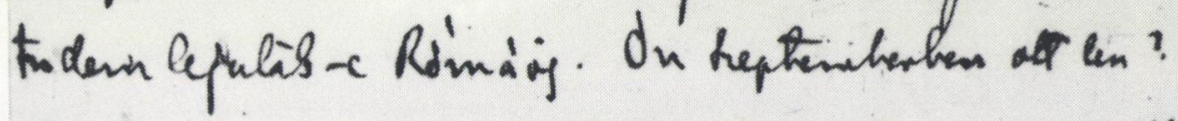

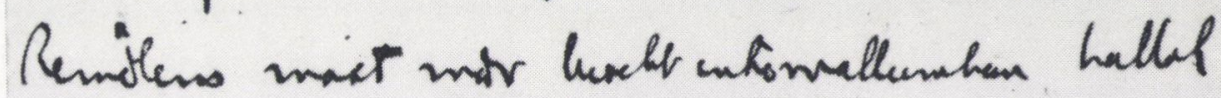

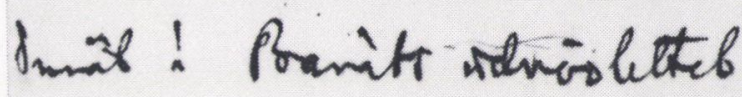

Anhina Guivo

A letter of György Lukács to Lajos Fülep 


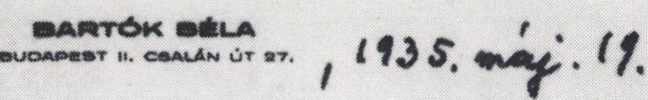

Nognielt. Palogeh yeno" unate

a M. Ted. Ath. fitithairainath.

Keoplinas Usam!

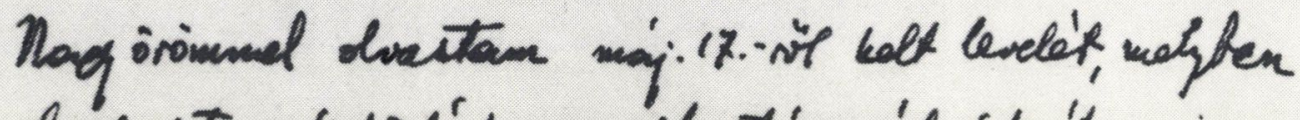

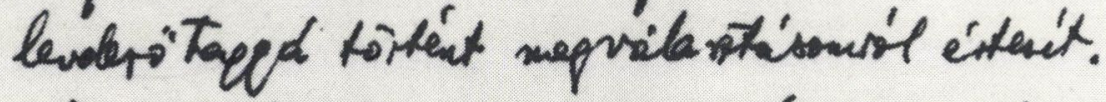

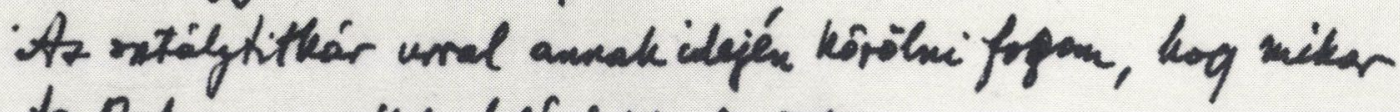

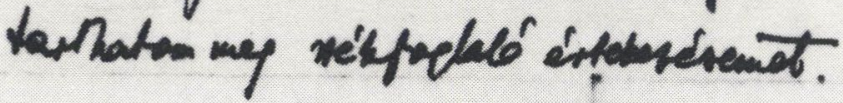

Nivalés Kusdatel

Dartít Déla

A letter of thanks by Béla Bartók for having been elected a member of the Academy 
Tgen tinteh Row in.'

Espidegulas Kuilsm a 2 caer. frizcket. alkal a Kirrszel. hoz a cimlaporo meyplöt addty fortitajával ellatus mietobe vima kizrom Nivesediés, De neen tulsifor fáradás Xerotnem a Közlen tó $8-9$ Ralam töryénes eyaliab 1. vermaká ativastan alaitenni. th almban nem okvackinil pritlaigs.

Esputed ciren Itiv. etsitiés $4 \mathrm{~m}$ megik gmábariketve mighe elarís xarit kiniimek a kotas,

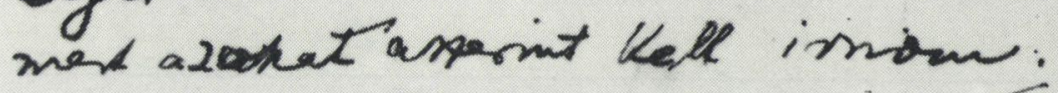

Rirnils Antelead

I. Voley -4. 1.

- kear lin Karil 7.

A letter of Zoltán Kodály to Ödön Beke 
Siprey 5. 5: 41

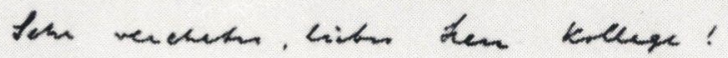

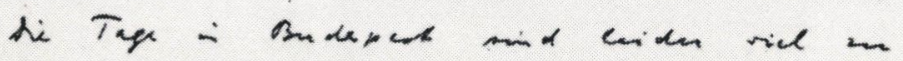

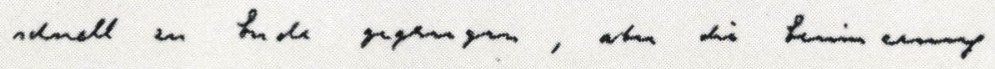

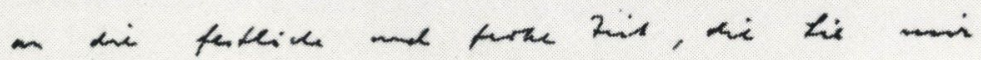

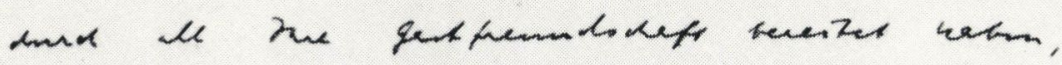

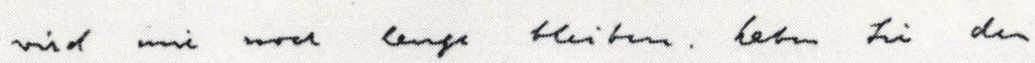

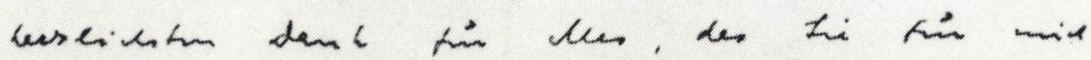

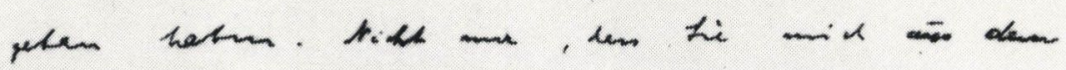

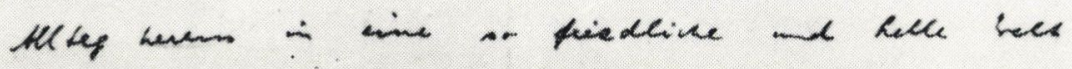

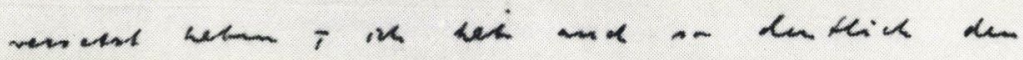

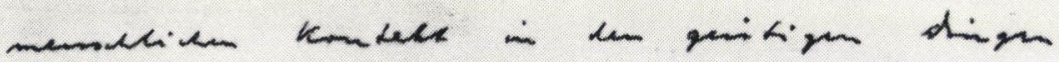

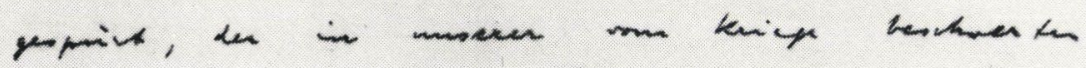
zid surs ar ackm is

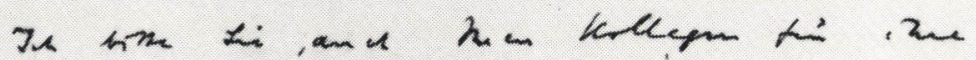

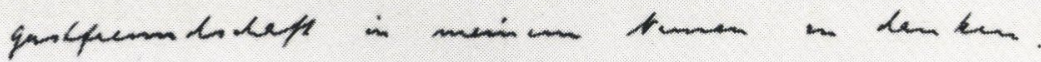

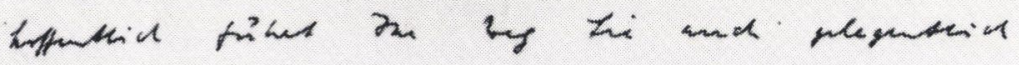

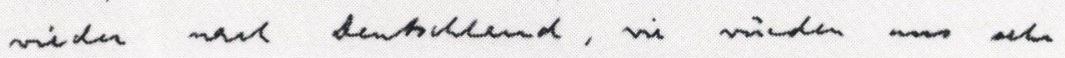
Sm truen Besual fremen.

In dambteckers

In sum exphemen

vene tusientey.

A letter of Werner Heisenberg to Rudolf Ortvay 
UNIVERTETETS INETITUT

TEORETSK FYaIK museansives s. Remewhuหk a.

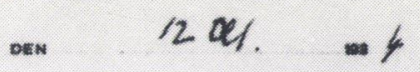

Kedres troliga in.

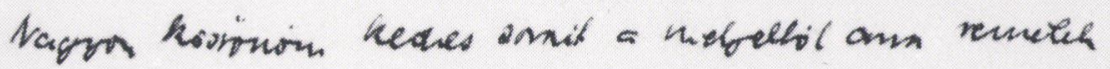

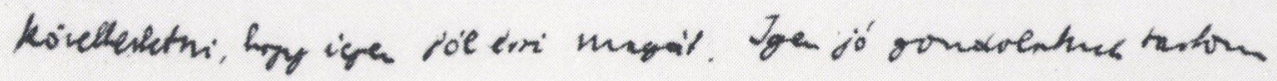

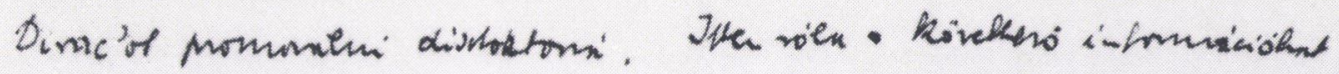

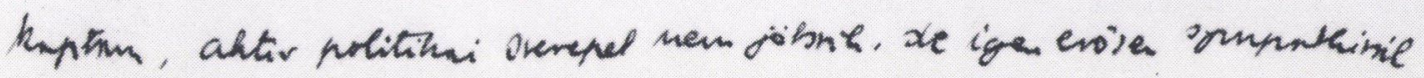

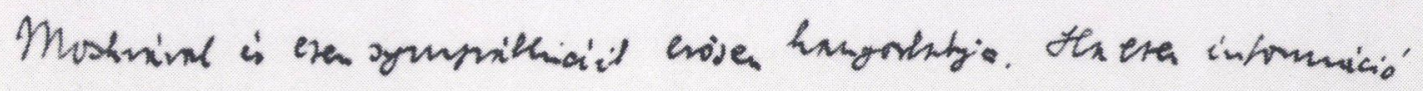

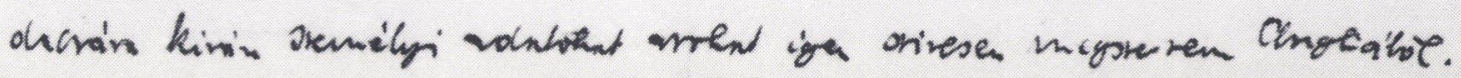

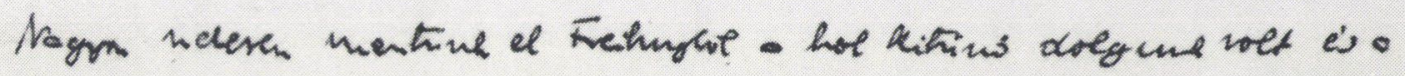

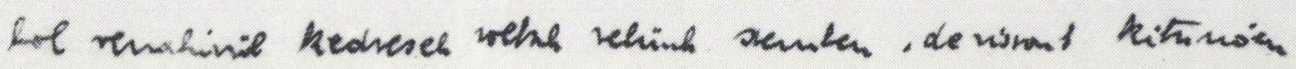

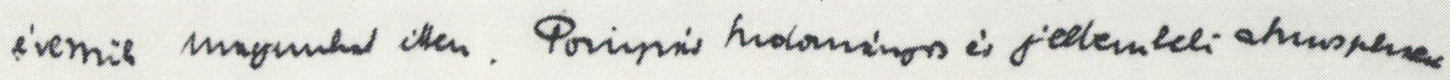

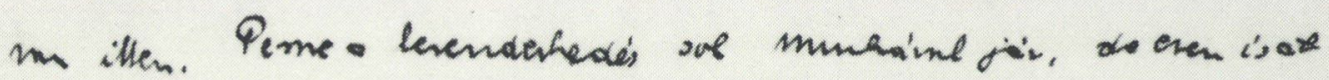
fogumb estri.

Aoys of kiven ciotrotlekemel kedre, magondingenzh.

Meleg solwilethe numans igan hir, hmib:

Hen

A letter of György Hevesy to Rudolf Ortvay 
FACULTÉ DES SCIENCES INSTITUt handi polncaRE

II, Rue Plerme-Curle (V)

The. : Opton 43-10
UNIVERSITÉ DE PARIS

$\rightarrow$ men-

Paris, le 27 Mai 1936.

Kedves Rudolf,

mont érkerett meg Dirac

Valarra, amelget medelkelue krildok. Att liszem, liogy ar alexala enlitet ajánlás ole cilnaveretaik lestuch. I'n nost még drole mindeneretre

Bormale is.

(A levil 5-ik sorában ala'káztan Raman nevét, es nyiluán egy iréshiba.)

Solsstor rioloröl, Manicte néserïl is,

Janni.

A letter of János Neumann to Rudolf Ortvay 
- Dófsa.

Heli véguar vidéke. viluaros, venedoluet septoto" inaka. diajuldi felhis Kofor tet-felbakvani bold.

a Rathafáros rogro nuagar vegvair billuetfje Kivi- ldgitot ablakolukal

- bol torik lovas dóors jö Ki.- Ung itiak a lonton - Fon a várat. Me tarian.

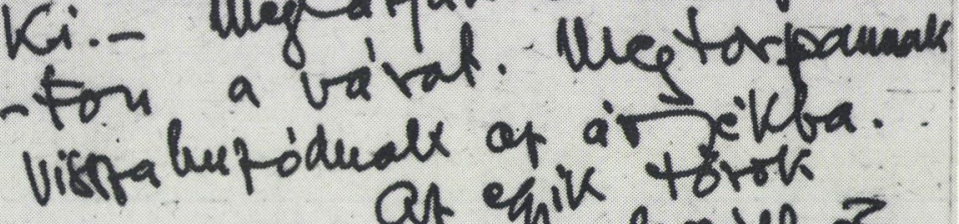
at eqik torok lovis -parauch- legdll \& nyilával dvaforam elore Ririk a var fele!

a gep kojelediv a värhor.estinsteu, ford. Hide

The script of a planned Dózsa-film by Béla Balázs 
pianid uile

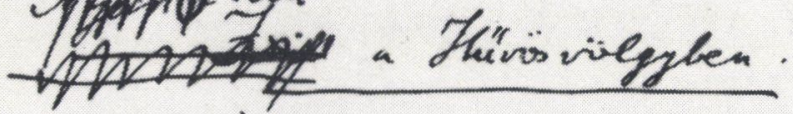

¿t lombokox vanaper yzain láz...

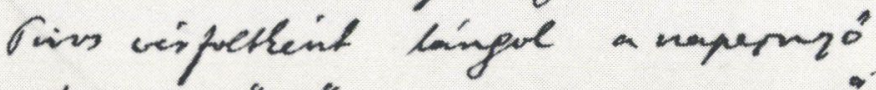

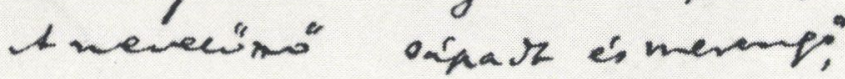
dristin a vïceghe kanirár.

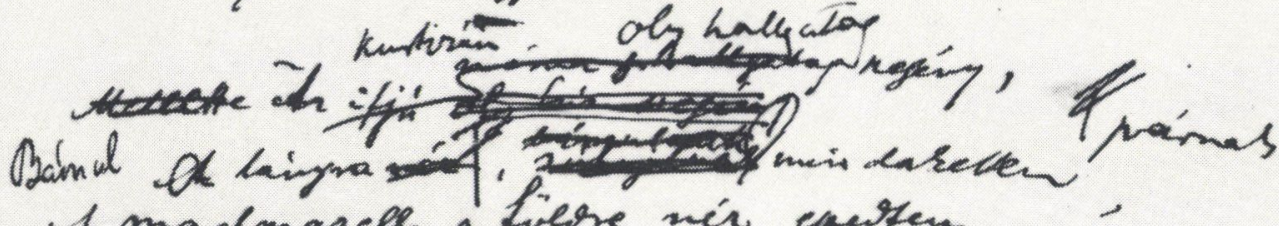
1 madmarele a fiere nér eperten. terelue saign francia reging.

Ans nogyt eirs, hat Mringive ithal

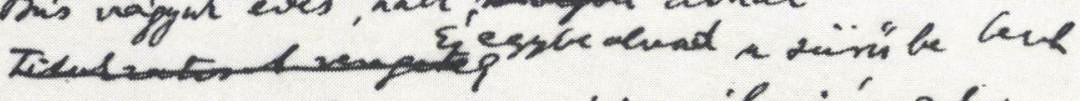

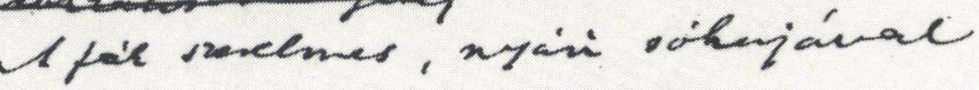
fiön fine. Fest tirs a semén,

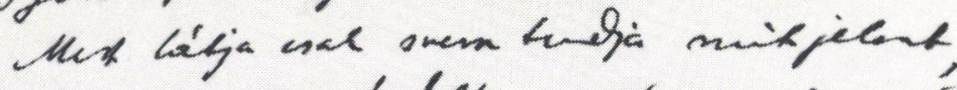

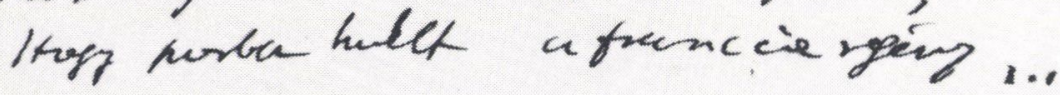

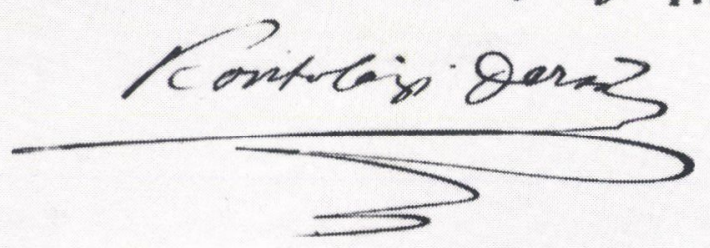

Kosztolányi Dezső: Idill a Hüvösvölgyben (A romance in Hüvösvölgy - A poem)

Szabó Lőrinc: Tücsökzene. A passage from a collection of poems 
Debrean II.

M. $4654 / 4$

Minilet perme sor tos entariey [163]

eltavtit; in well cistiputelig

is ma is ig ram, ex a girs varis

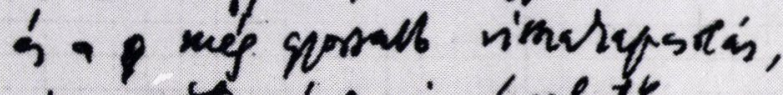

odf. eqti mé ma is ćresheto

a heneidember $y-y$, torkeno:

pytom winte netrootan tegien

s's uhom ome, mestorreferem,

a rebieit : n's rásalieloorm

vilamine í clobrarorsm - -

o vina firteren: / holis haptam $d$ ?

(Voll maí, hon heir versed twanatel,

ristben, s-mominat - as Habémiain,

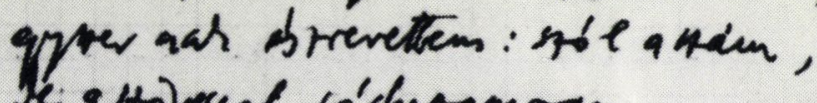
He a tolugel paishuramoom

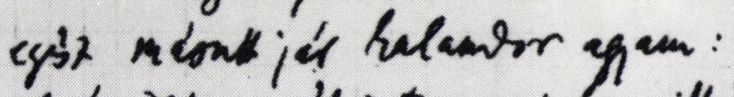

elrémiltem: Uniten, mi less itt....

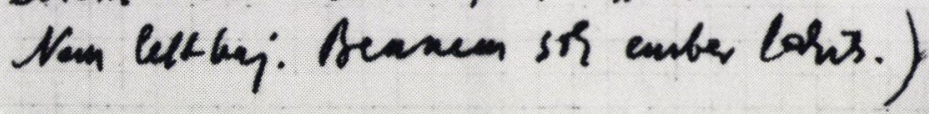




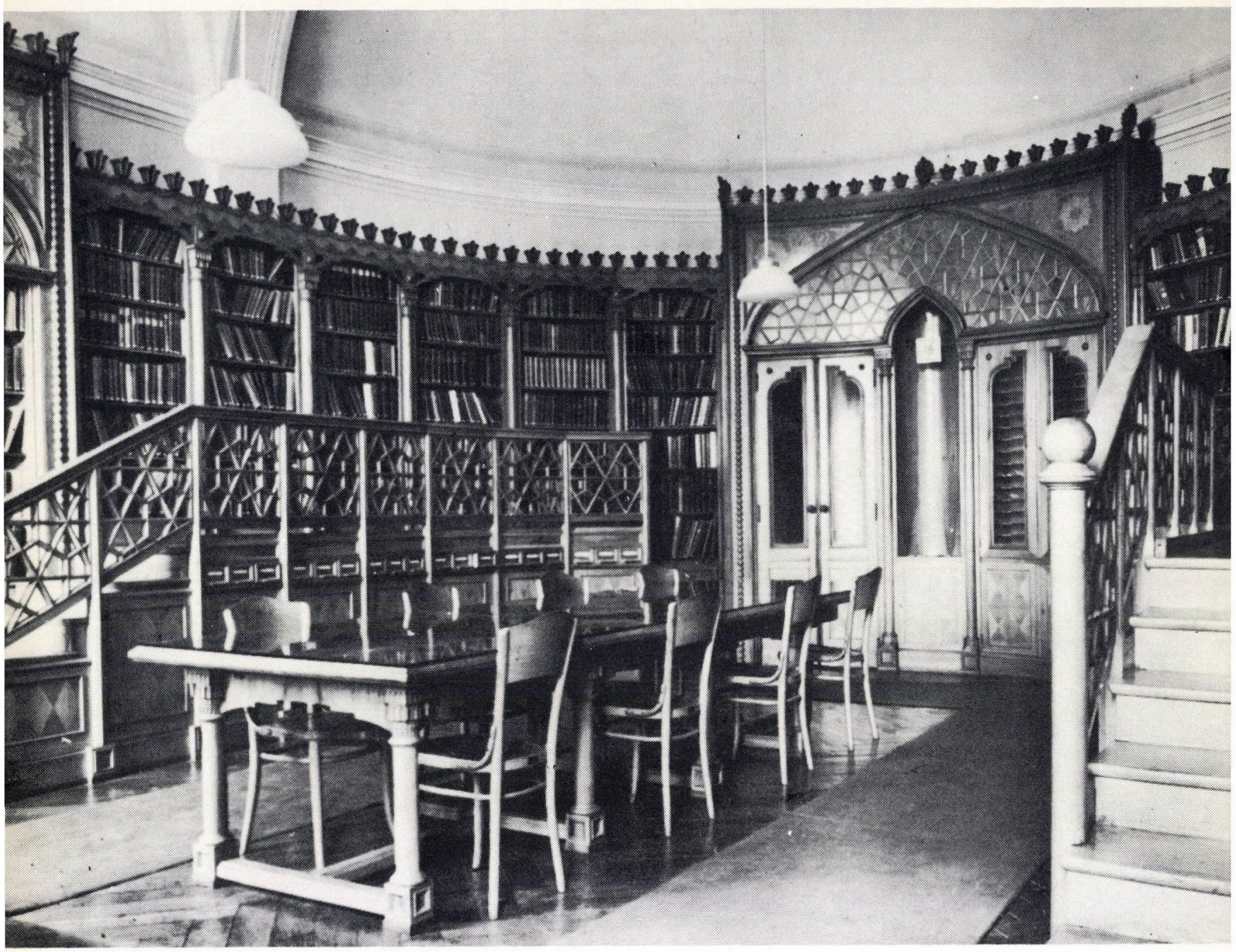

The reading-room of the Oriental Collection

Mahzor. A Hebrew manuscript from the 15 th century 


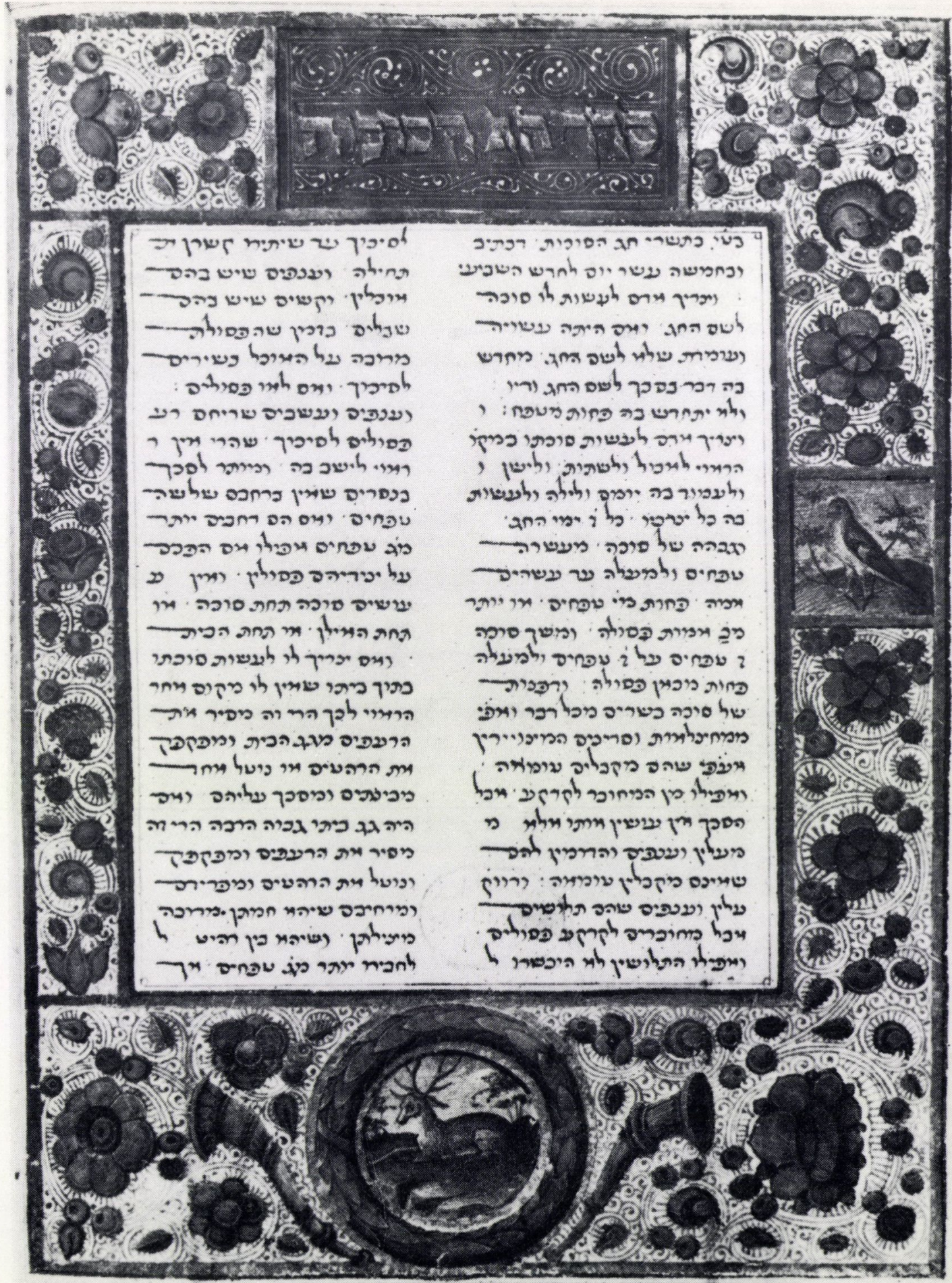


Mishnah Thora by Moses Maimonides

Hebrew manuscript from 1310

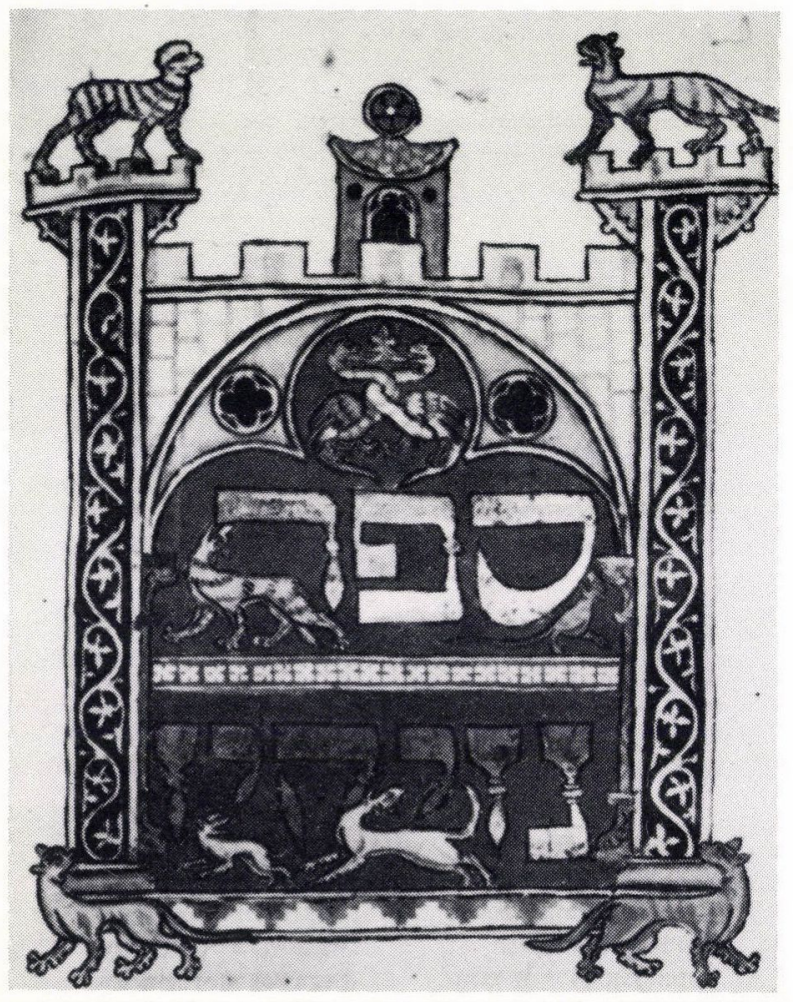

Mishnah Thora by Moses Maimonides

Hebrew manuscript from 1296

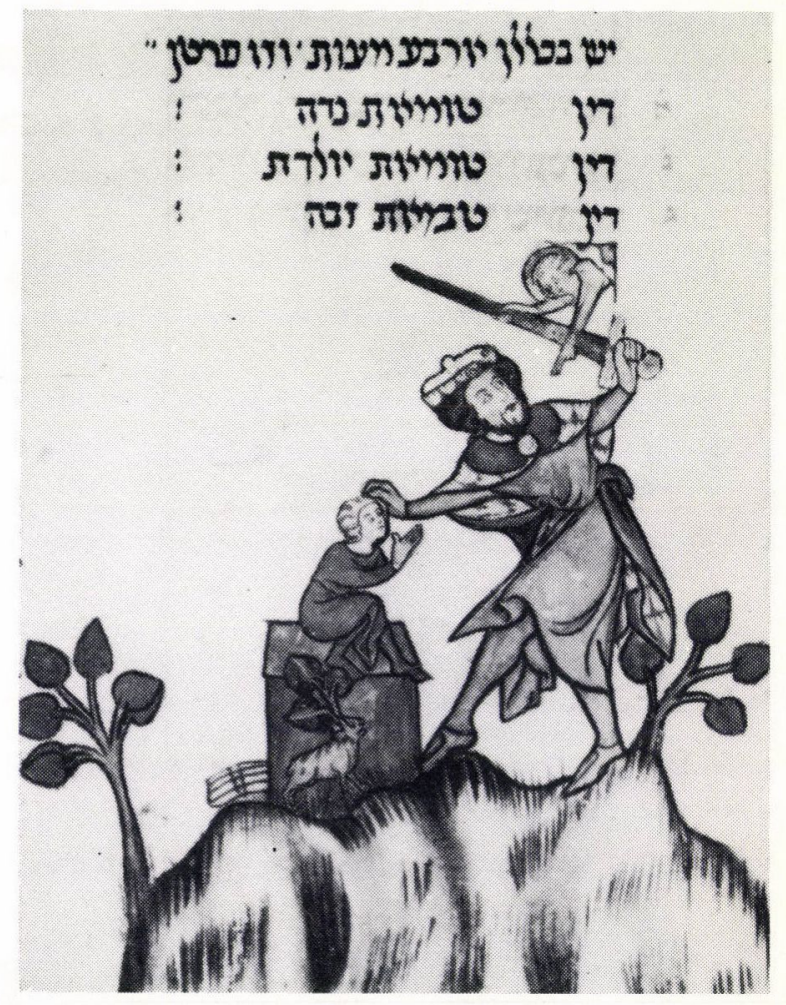




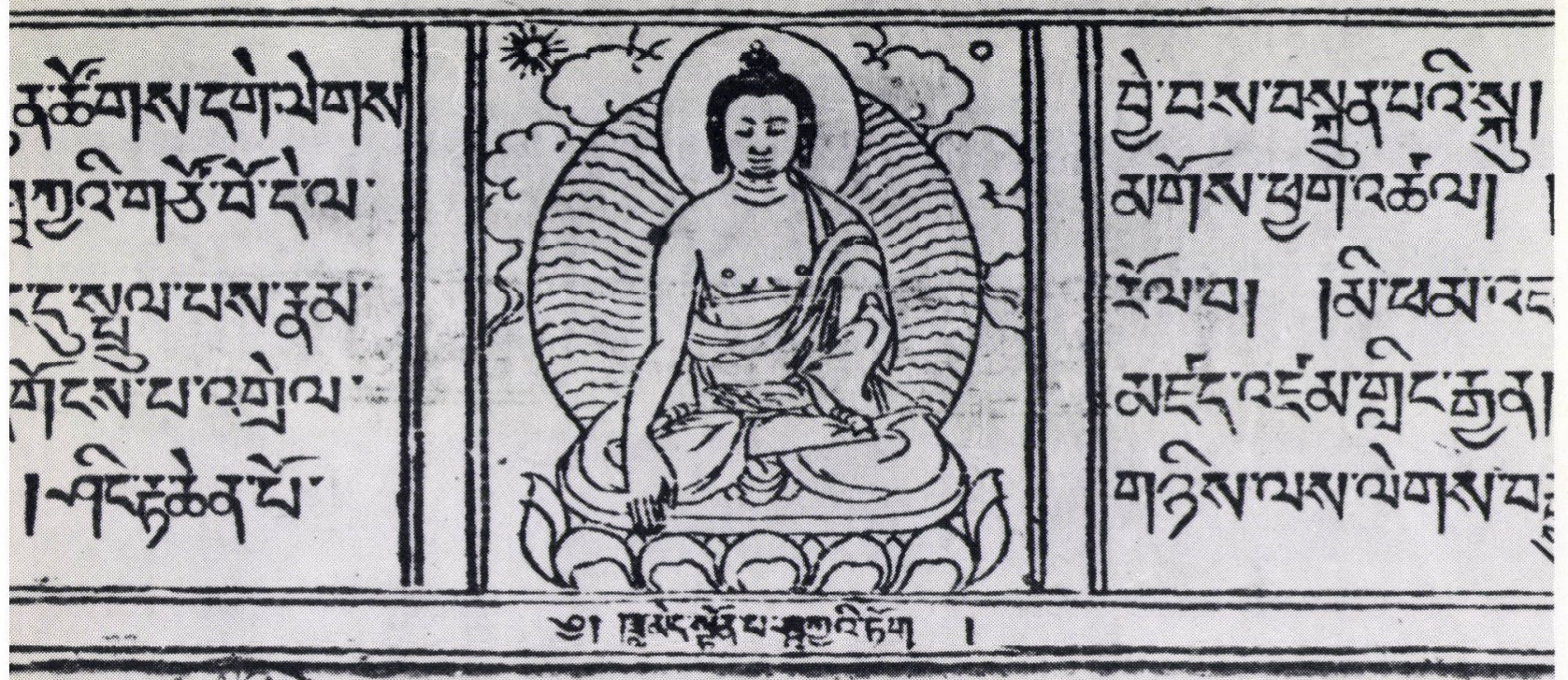

Lam-rim. A Tibetan xylograph

Portrait of Sándor Körösi Csoma

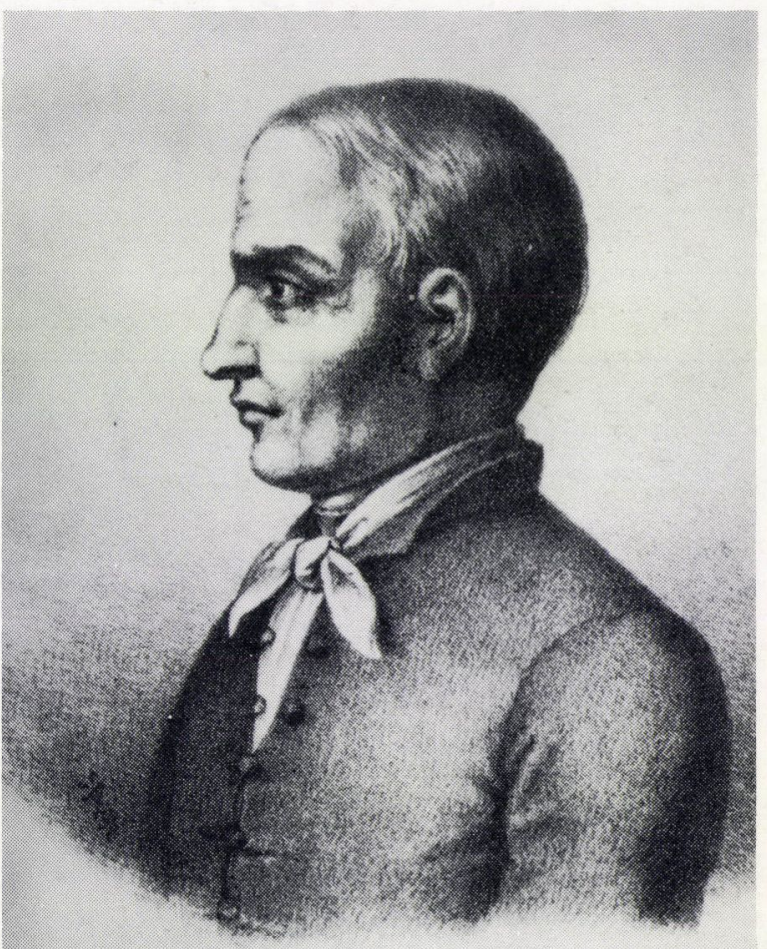


$=9 x+2+: C \times h=h \nabla-3 h=\sigma B T g \circ+:$

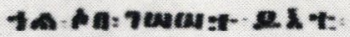

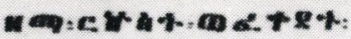

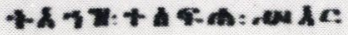

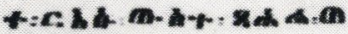
Ac: a-at=a pc:arrt

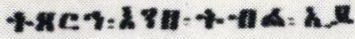

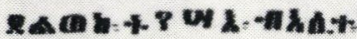

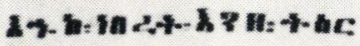

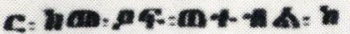

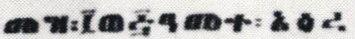

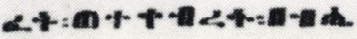

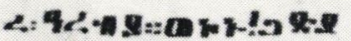
z: cost:ab-at:a-1t

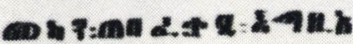

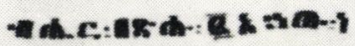

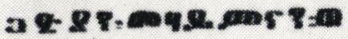

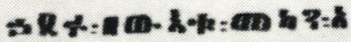

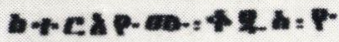

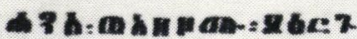

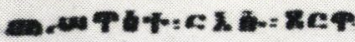

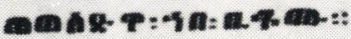

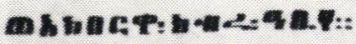

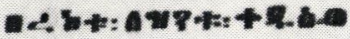

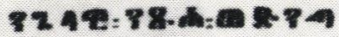

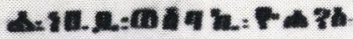

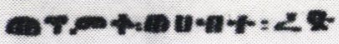

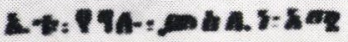
$\checkmark e$

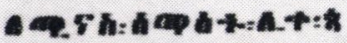

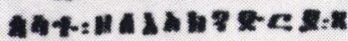

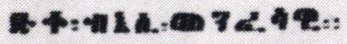

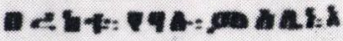

ex: $:$ : :2

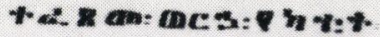

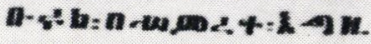

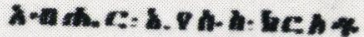

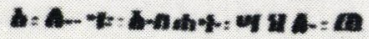

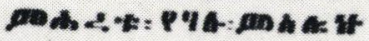

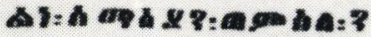

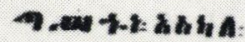

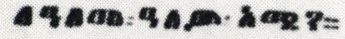
:* *:

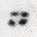

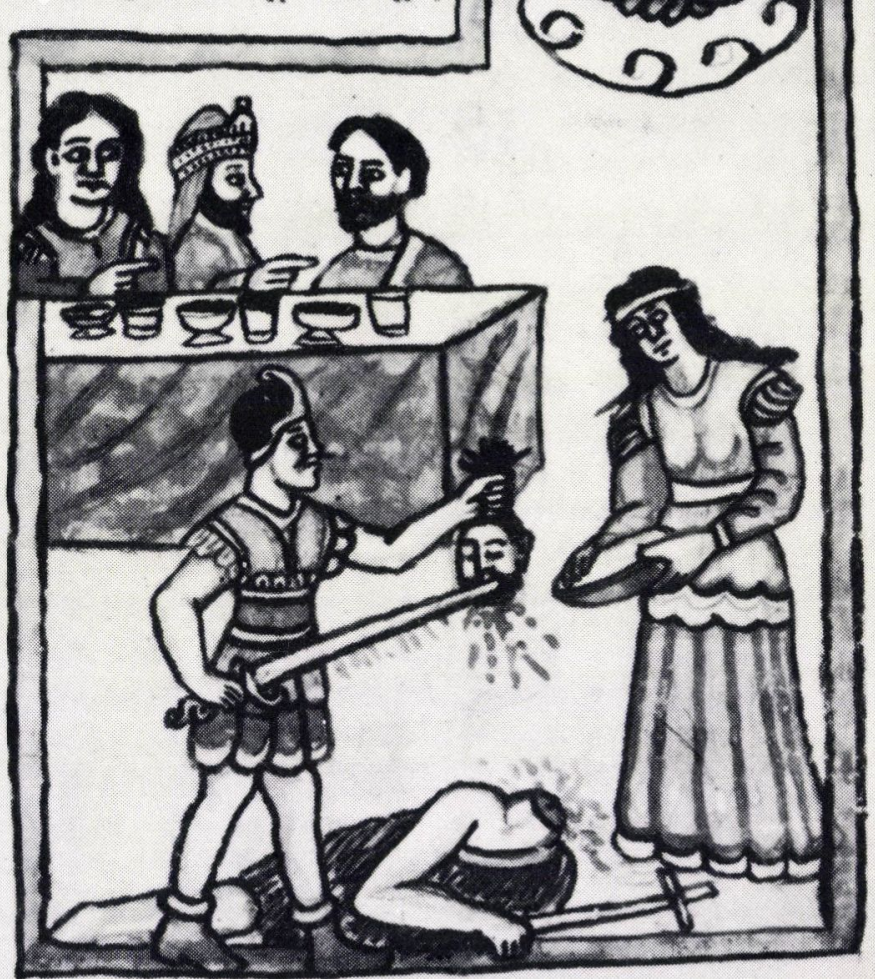

Bible. A Ge'ez manuscript from the 17 th century 
An Islamic prayer-book. Arabic manuscript from the 18 th century
Kitab hadikat ul zurafa. An Osmanli-Turk manuscript from 1782
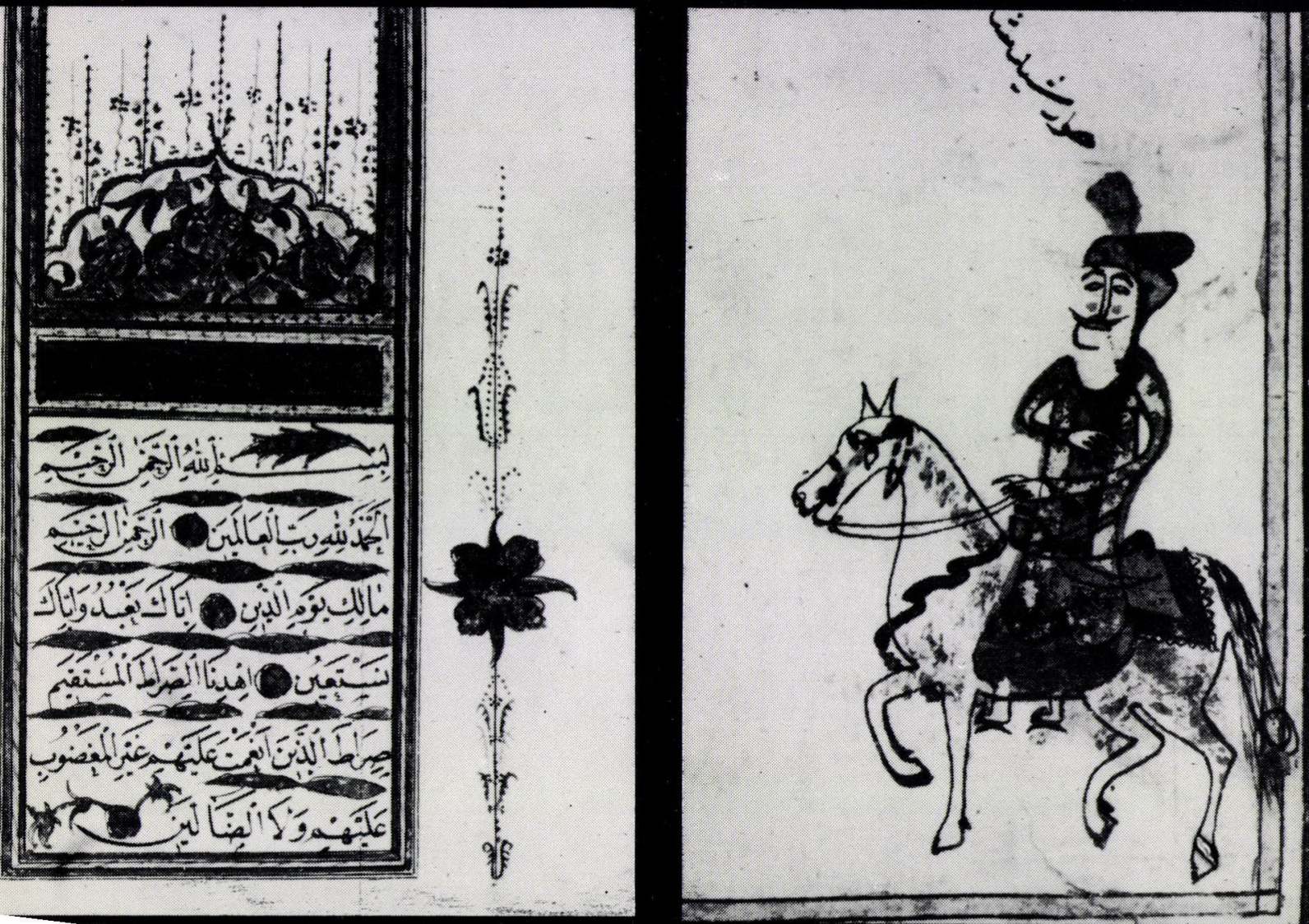


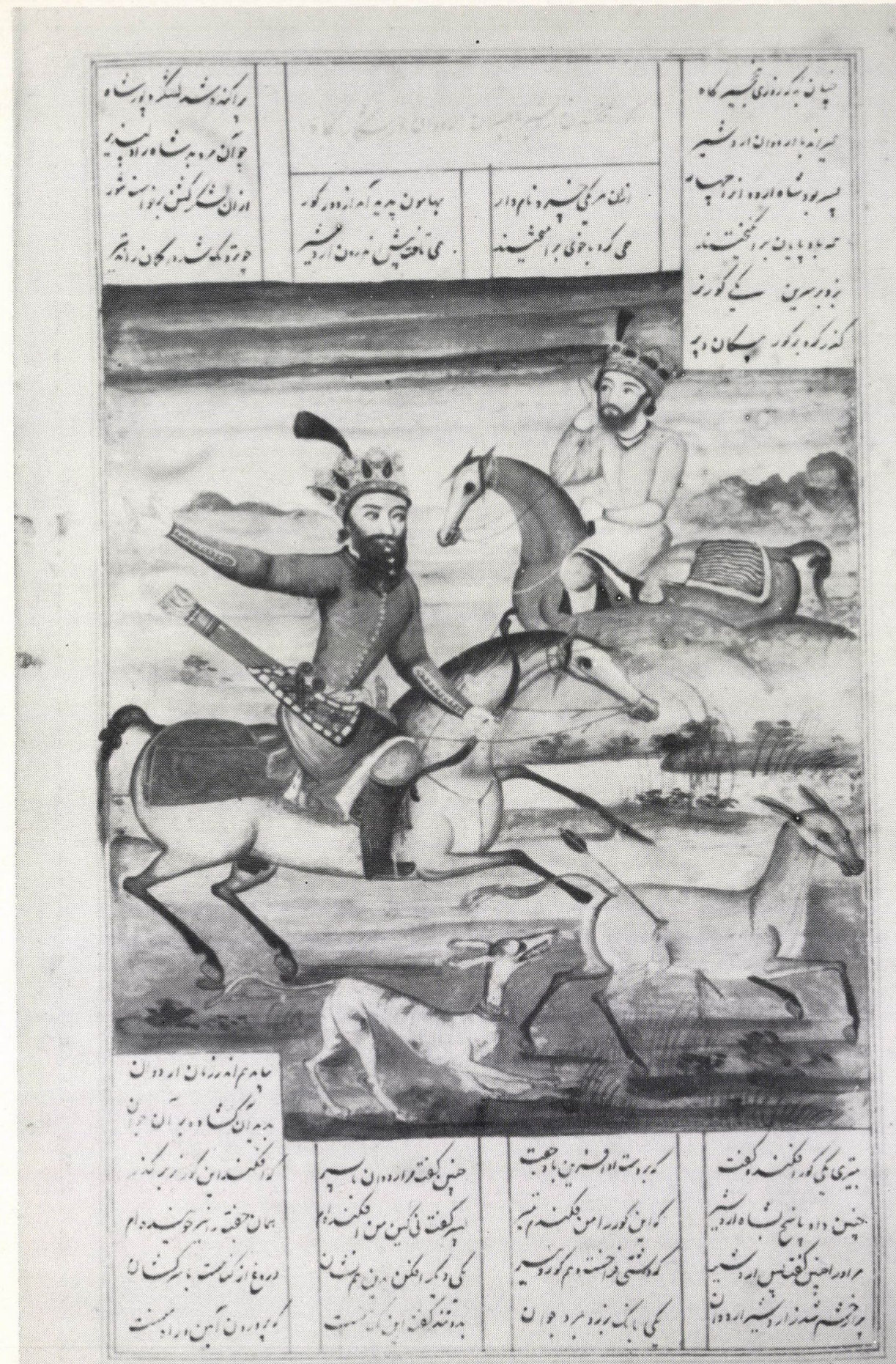


4 Firdausi: Shahname. A Persian manuscript from the 18 th century

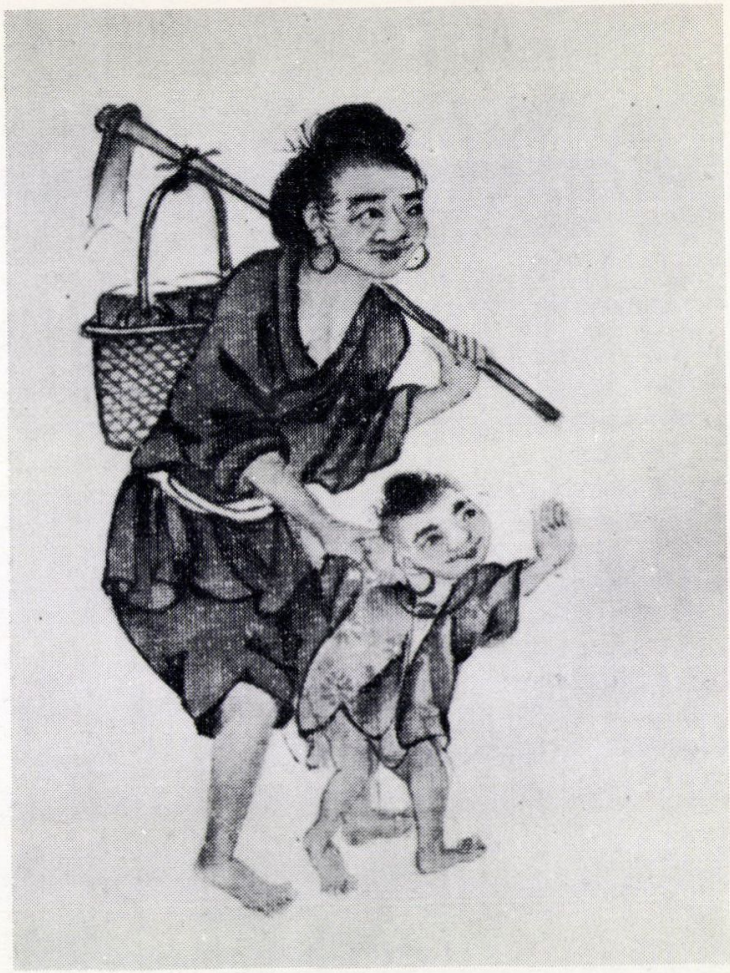

Man ji ji su che. Chinese painted silk

A Sanscrit manuscript from

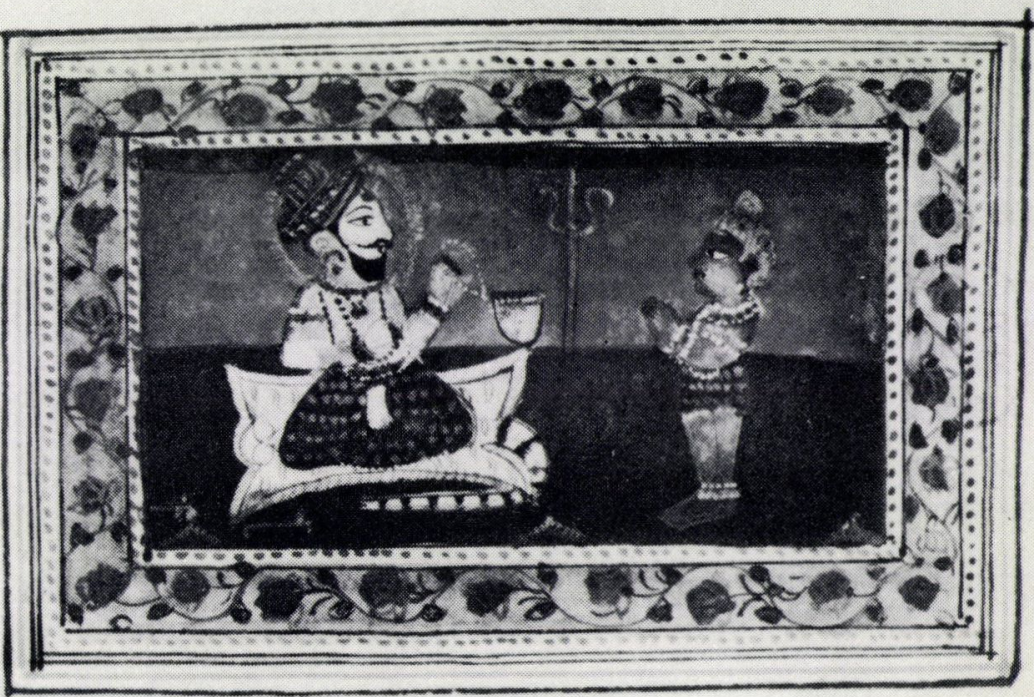
the 18 th century 
Les Solyilor! Bute De k for

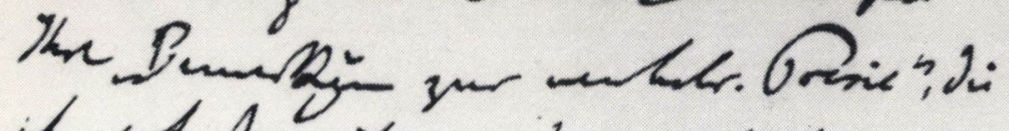

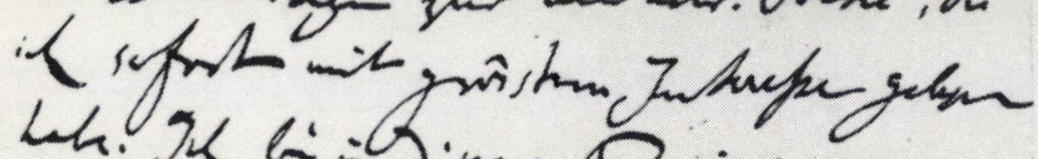
wh. gh bi Siver Fonig my

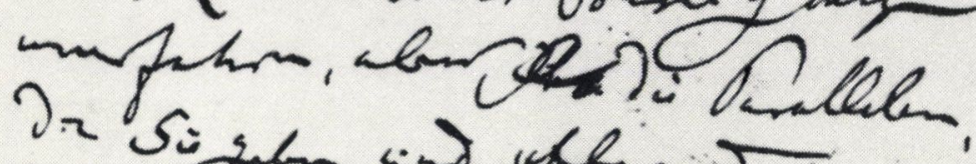

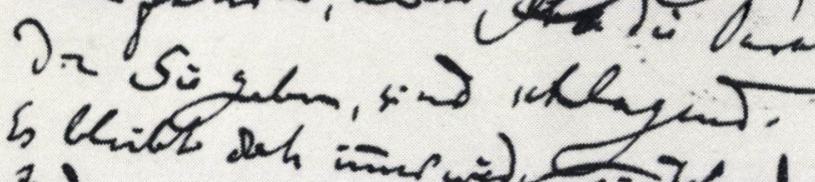

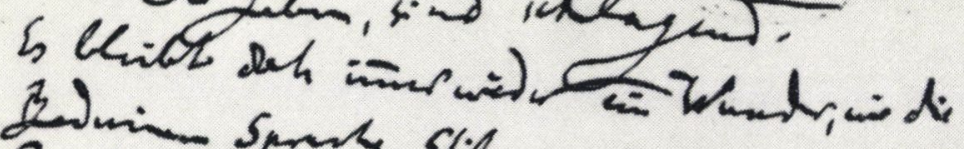

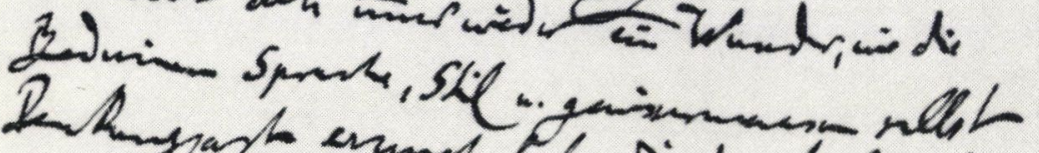

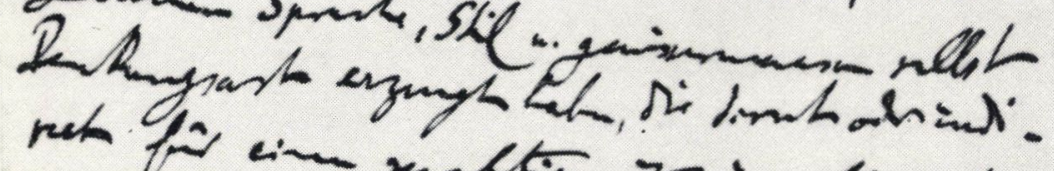

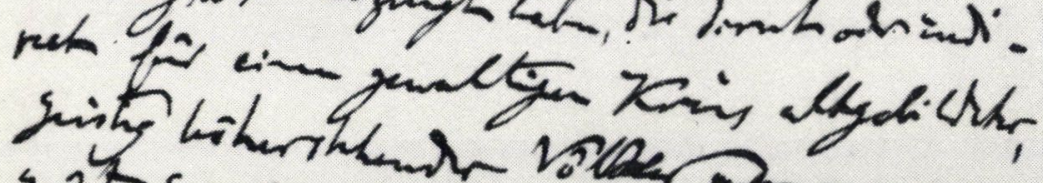

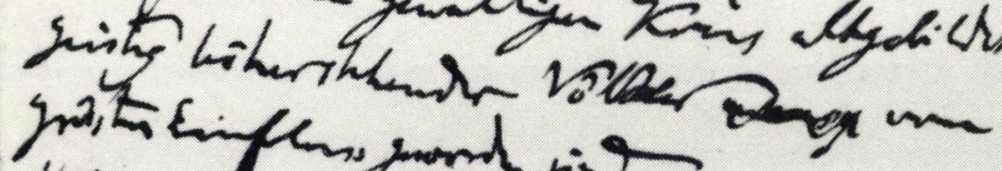

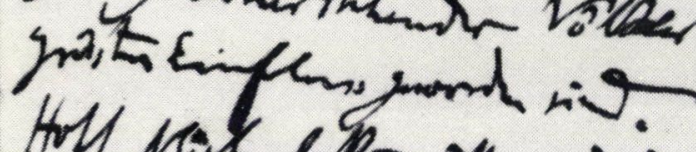

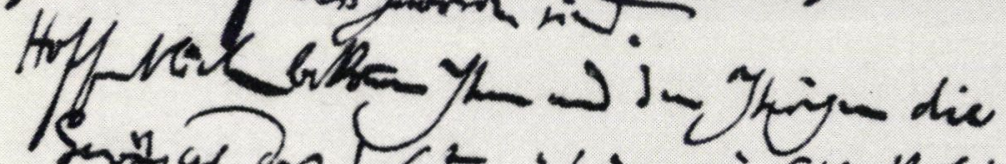

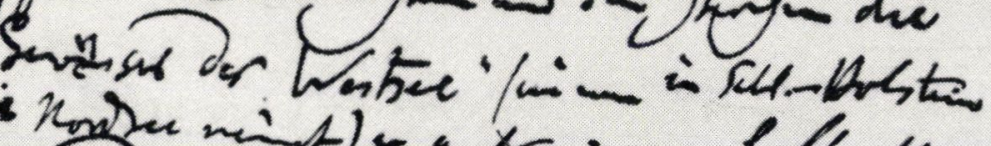

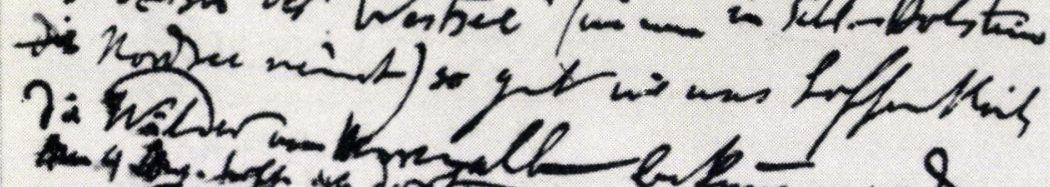
ia $\int_{2}^{2}$ the

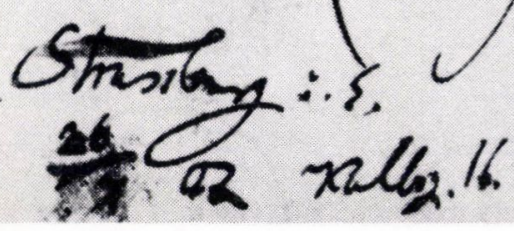

A letter of Theodor Nöldeke to Ignác Goldziher 


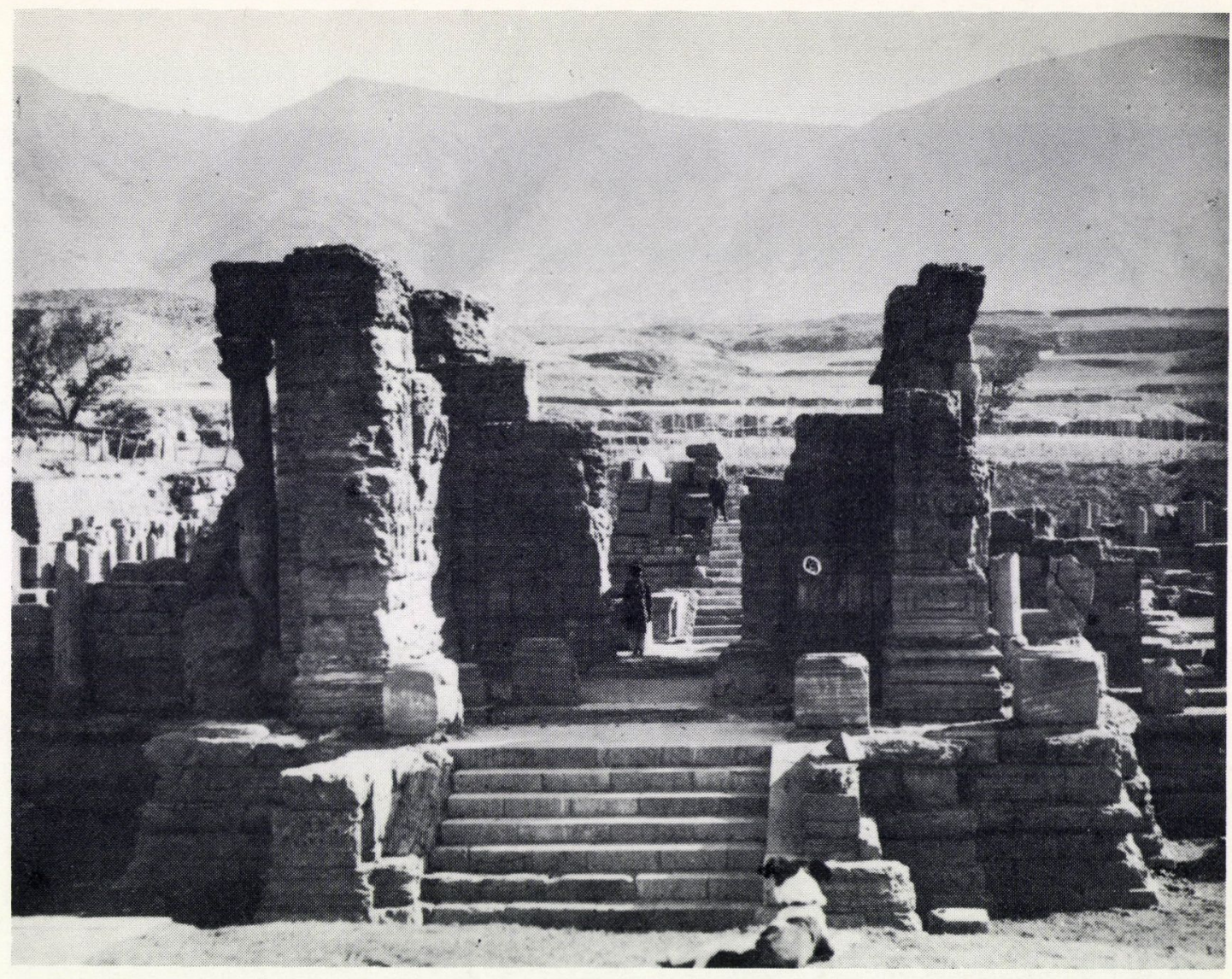

An original photo of 'Avantipur' from the collection of Aurél Stein 
Felelős kiadó: az MTA Könyvtára igazgatója

Felelős szerkesztő: Fekete Gézáné

Szerkesztö: Deák Lászlóné

Müszaki szerkesztő: Sasvári Károly

Alak BN/12 - Terjedelem 13,9 (A/5) ív

Megjelent 1976 - Példányszám: 1500

Készült az MTA KESZ Sokszorosítójában 767973

F. v.: Szabó Gyula 
$50 \mathrm{Ft}$

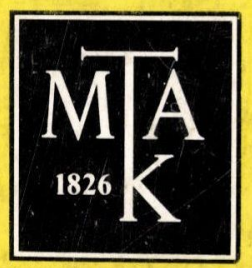

